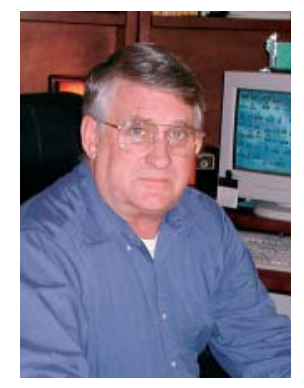

By Gary Frasier

\section{Frasier's Philosophy}

A wet spring followed by a hot, dry, early summer is a recipe for major fires. As I write this, the Governor of Montana has declared the state a major disaster area with uncontrolled fires of thousands of acres burning in several locations. Other areas of the country are deluged with multiple extended rains in excess of several inches causing major flooding. This is the pattern in much of the West. There is too much water in some areas and too little in others. As much as we would want to we can not change this pattern. We must live with it.

Water seems to be on everyone's mind. Cities in the West are growing and to support this growth they need more water. Where is it coming from? It comes at the expense of the farmers and ranchers who are living on our vast range and farmlands. Water needed to maintain mountain meadow ranches is going downstream to the cities. In much of the West the water in our streams and rivers is allocated based on prior use. The earliest settlers that used the water beneficially first have the earliest right. The cities have bought the prior water rights. The ranchers and farmers are left in the dust. Ranchers are told to do the best they can. Times are changing.

The early settlers of the West came from areas that supported various trees. Much of the areas they came to were primary low vegetation types that had developed under a fire regime. They brought cottonwoods. Ornamental shrubs such as tamarisk were planted as windbreaks and privacy fences. These were nice but they were also water-loving invaders. Today these two plants are using ground water at a rate that is affecting the stream flow in many rivers. Going back to the vegetation conditions along our rivers and streams of several hundred years ago is almost an insurmountable task. We must change.

These problems are not unique to the United States, Canada, and Mexico (primary areas of SRM members). These problems are occurring in many areas of the world. Just talk to range managers who have worked outside of the United States and Canada. They will tell you that change is occurring on all rangelands of the world. We cannot abuse the land as has been done in the past. This is a recognized fact from the simple herder to the governmental land manager. There must be changes in range management or there will not be a rangeland resource for the future. We must move forward.

What does this mean to the range management profession? We have the knowledge to live within these changing conditions and still maintain our country's heritage and natural resources. It takes a unified effort of many scientific disciplines dealing with plant, soil, water, and animal (domestic and wildlife) resources. It takes an understanding of the social philosophy and economic factors of living on a land under conditions that are not always under the person's control. We must adapt.

The trained range manager is a unique person who can integrate all the scientific disciples that it takes to manage the rangelands. In most parts of the world the number of people 
involved in range management is decreasing every year. As the problems grow, we see fewer and fewer people with fewer and fewer resources to cope with the tasks. We cannot let this continue or there will come a time when we no longer have good drinking water for our cities. We will not have our vast wildlife resource for our sportsman. We will not have our open spaces for hiking, camping, silence, and solitude. We need to keep our range managers. This includes the people who make a living from the land, our ranchers and farmers. We have a generation of people who have never experienced the hardships of making a living from the land, such as a farmer or rancher. They do not understand the long hours of hard work and the small monetary rewards you get from living and working our rangelands. The range management profession would not be here without these people. Let us forget our differences and work toward the common goal of maintaining our rangelands for the future of all. Otherwise all is lost. 


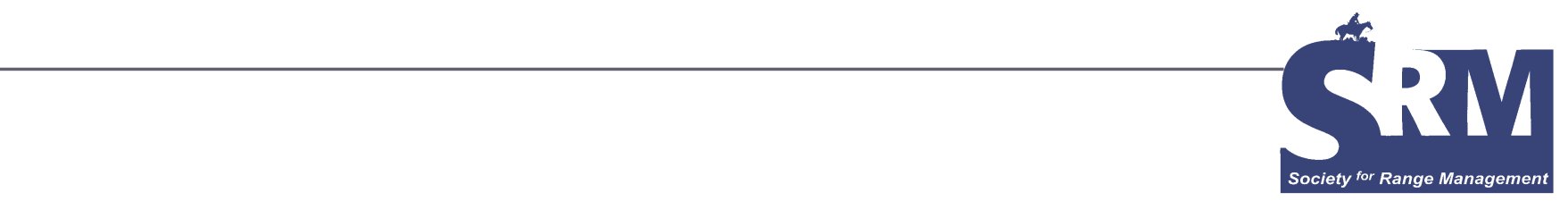

\section{Ranchers as a Keystone Species in a West That Works}

\section{By Richard L. Knight}

Editor's Note: This paper is a portion of the presentation by Dr Knight at the Plenary Session, Society for Range Management, Reno, Nevada, February 12, 2007.

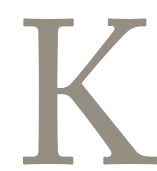

eystone species - a species whose importance is disproportionate to its numbers.

Ranchers and ranching are both an occupation American West. As the landscape of the West is blended, half public and half private, ranching builds connections between public and private lands, and between rural and urban communities. Ranching works well, ecologically, economically, and culturally. If ranching declines rather than prospers, so too will the health of human and natural communities decline.

Ecologically, ranching as a land use is compatible with the natural heritage of the West. It keeps lands open and stewarded, keeps human densities low, and safeguards private lands from fragmentation. Economically, ranching provides home-grown food, pays its own way, and supports a fiscally responsible economy. Culturally, ranching covers a time frame dating back over 400 years, one of the oldest land uses that Euro-Americans have given the New World.

A natural alliance exists between urban consumers of food and open space, and rural producers of food and open space. Regretfully, this logical symbiosis has waned during past decades. A strong rural-urban partnership is as essential to a healthy West as is a strong public-private land connection. As these relationships deepen, so too will the health of the human and natural communities of this region. ${ }^{1}$

A honest appraisal about ranching as a land use in the New West, however, first requires that we acknowledge the current "highest and best uses" of the West, both private and public. Exurban development and outdoor recreation are presently the highest and best uses of the private and public lands, respectively, in today's West..$^{2,3}$ These land uses have replaced livestock grazing as the principle use of the West only decades earlier, particularly in the arid West. ${ }^{4,5}$

Because land health is dependent upon land use, it is impossible to discuss ranching without also discussing the land uses that are replacing it. Some people might think it is a far stretch to connect livestock grazing on private and public lands with exurban development and outdoor recreation on private and public lands, but I see it differently. The protection of open space, food production, ecosystem services, and the aesthetics of rural areas runs right through agriculture. At one end stands a rancher, at the other end a developer. We have arrived at a point in our history where conversations about western lands and land health, grazing, ranchettes, and recreation are entwined and cannot be separated. They must be dealt with simultaneously when discussing the future of our Next West. Importantly, these discussions need to include more than just the ecology of competing land uses; they also need to address the economics and the cultural aspects of these land uses as well. ${ }^{6}$

\section{Ecology}

Although land ownership in the West is blended, the division is not equal. The private lands are the best-watered, occur at the lower elevations, and contain the richest soils. ${ }^{7,8}$ Understanding the history of settlement of the public domain is key to appreciating why the federal lands are largely "rock and ice" or "desert and thorn." The implications to biodiversity of this historical truth are even more 
important. The private lands are disproportionately important to the maintenance of our region's natural heritage because they are disproportionately more productive. Although no one has calculated the ratio, private lands may be an order of magnitude more important to the maintenance of the region's biodiversity than are the public lands. Truthfully, however, species of conservation concern could no more survive on just the private lands of the West than they could survive on just the public lands.

Ranching, because it encompasses large amounts of land with low human densities, and because it alters native vegetation in modest ways, has been found to support biodiversity that is of conservation concern. The alternative uses of private and public lands do not tread so lightly. Outdoor recreation is the second leading cause for the decline of Federally threatened and endangered species on public lands, and residential development is the second leading cause for the listing of these species on all lands in the United States, both private and public., ${ }^{9,10}$

Whereas ranching is synonymous with minimal human visitation and structures, both exurban development and outdoor recreation are year-round activities of elevated human densities that both perforate and internally dissect land with roads, trails, house sites, and recreational facilities (camp sties, picnic areas, viewing areas). ${ }^{11}$

When rural lands, whether in farms or ranches, are subdivided, there follows an increase in landscape-level fragmentation. For example, when ranches in Larimer County, Colorado were subdivided, there was an almost ten-fold increase in road densities and fragmentation from houses that perforated the previously intact rangelands. ${ }^{12}$ This observation led us to wonder how biodiversity, from songbirds to carnivores to plants, differed across the principle land uses of today's West. Accordingly, we examined these taxa on a landscape that was part ranchland, part exurban development, and part protected area without livestock. ${ }^{13}$

We found that the ranchlands and protected areas supported birds and carnivores of conservation concern, while the exurban developments supported pretty much the same songbird and carnivore community one found in suburban areas in town (Figs. 1-3). The plant story was a little different. Both the protected areas and the exurban developments were far more weedy than the ranchlands (Fig. 4). ${ }^{14}$ Stewardship, the judicious use of herbicides and livestock, and a discerning eye were the differences here. Ranchers apparently are doing what Aldo Leopold suggested when he wrote, "The central thesis of game management is this: game can be restored by the creative use of the same tools which have heretofore destroyed it-axe, plow, cow, fire, and gun." 15

Critical to understanding the edge affect associated with fragmentation by ranchettes is the awareness that species composition changes as a result of the homes. Human-adapted species, such as brown-headed cowbirds, black-billed magpies, and American robins, all occurred at higher densities near homes and at lower densities away from homes. These species can affect the fitness of birds of
Black-billed Magpie

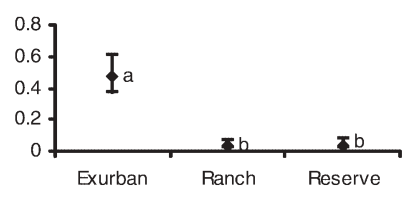

Brewer's Blackbird

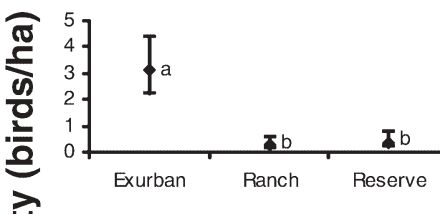

House Wren

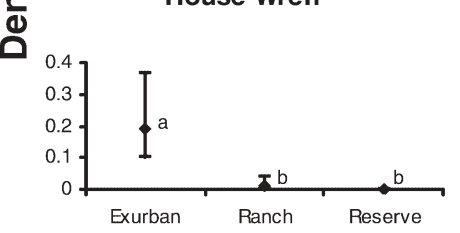

Bullock's Oriole

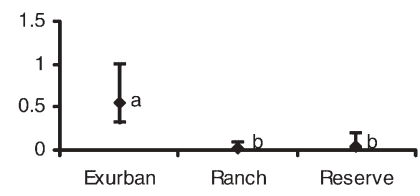

\section{Land use}

Figure 1. Densities and $90 \%$ log-based confidence intervals of bird species that reached their greatest densities on land used for exurban development. Different letters next to density estimates indicate a statistically significant difference at the 0.10 level.

conservation concern through nest parasitism, nest predation, and competition for nesting sites, respectively.

When ranches support viable populations of species sensitive to the harmful effects of sprawl, they serve much the same role as protected areas because they act as "sources" (areas where birth rates of species exceed death rates) of sensitive plant and animal species. If ranchettes serve as "sinks" (places where death rates exceed birth rates) for species of conservation value, populations on these areas are kept afloat by the addition of surplus individuals dispersing from nearby protected areas and ranchlands. ${ }^{16}$

The upshot of the biological changes associated with the conversion of ranchlands to ranchettes will be an altered natural heritage. ${ }^{17}$ In the years to come, as the West gradually transforms itself from rural ranches with low human densities to increasingly sprawl-riddled landscapes with more people, more dogs and cats, more cars and fences, more night lights perforating the once-black night sky, the rich natural diversity that once characterized the rural West will be altered forever. We will have more generalist species-species that thrive in association with humansand fewer specialist species-those whose evolutionary 

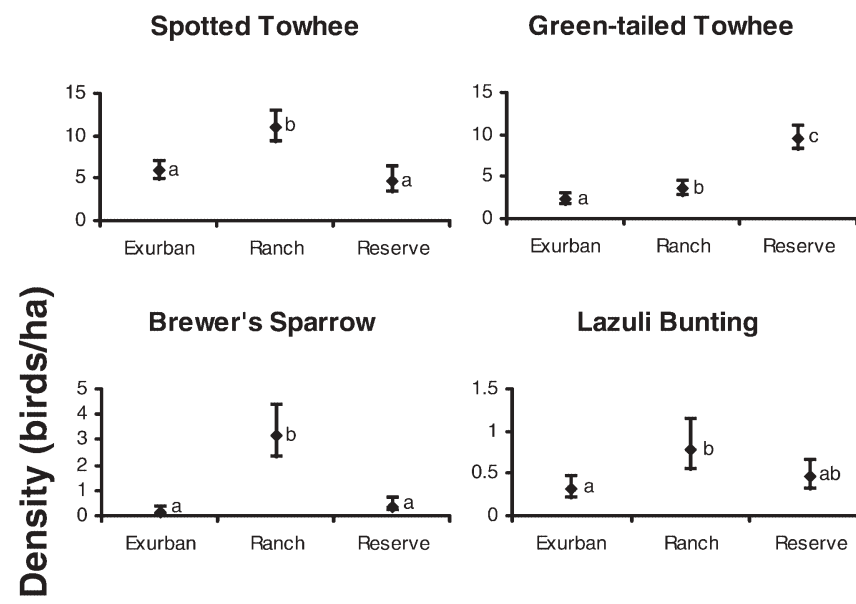

Vesper Sparrow
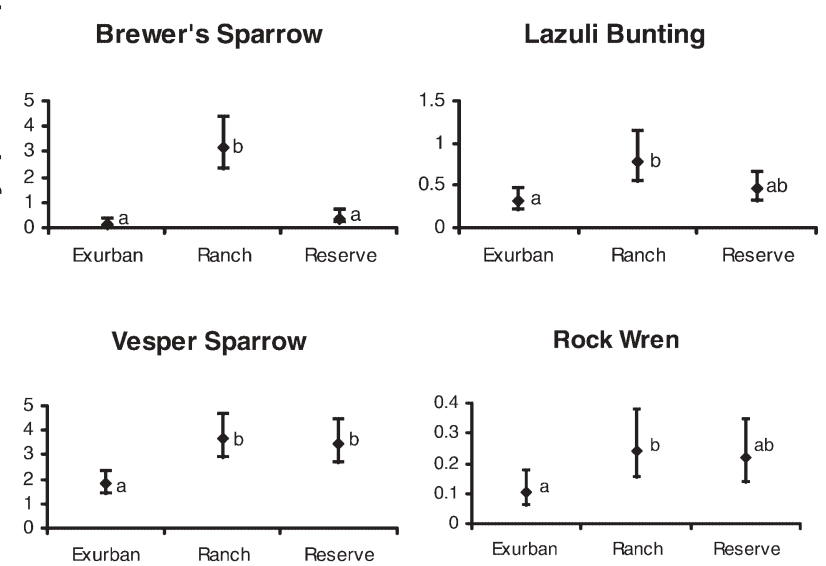

Rock Wren

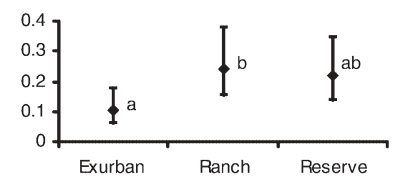

\section{Land use}

Figure 2. Densities plus $90 \%$ log-based confidence intervals of bird species that reached their greatest densities of land used for ranching or reserves. Different letters next to density estimates indicate a statistically significant difference at the 0.10 level.

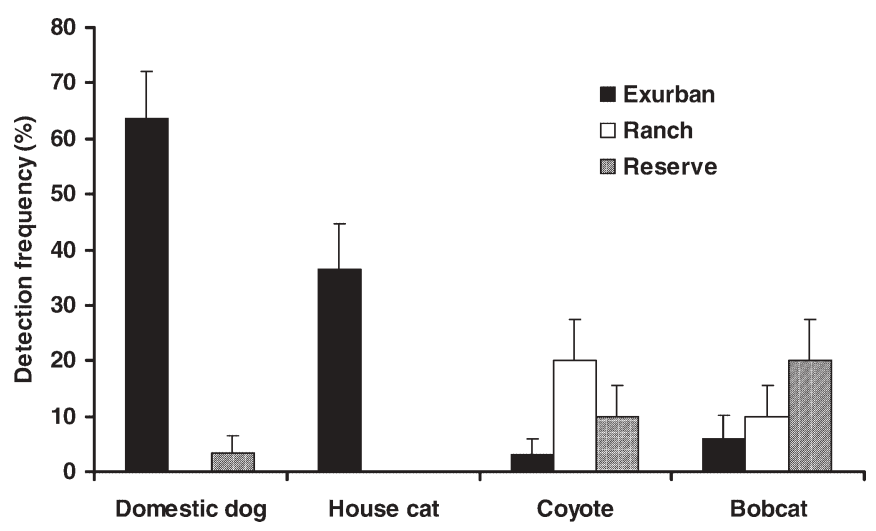

Figure 3. Frequencies ( \pm SE) of carnivore detections at scent stations surveyed on exurban developments, ranches, and reserves.

histories failed to prepare them for elevated human densities and our advanced technology. Rather than lark buntings and bobcats, we will have starlings and striped skunks. Rather than rattlesnakes and warblers, we will have garter snakes and robins. Is that the West we want? It will be the West we get if we do not slow down and get to know the human and natural histories of our region better, and then act to conserve them.

Livestock grazing on public lands is believed by some to threaten biodiversity..$^{18}$ But is it? One of the most thorough analyses on the ecological effects of grazing on public lands compared 26 long-term grazing exclosures with similar

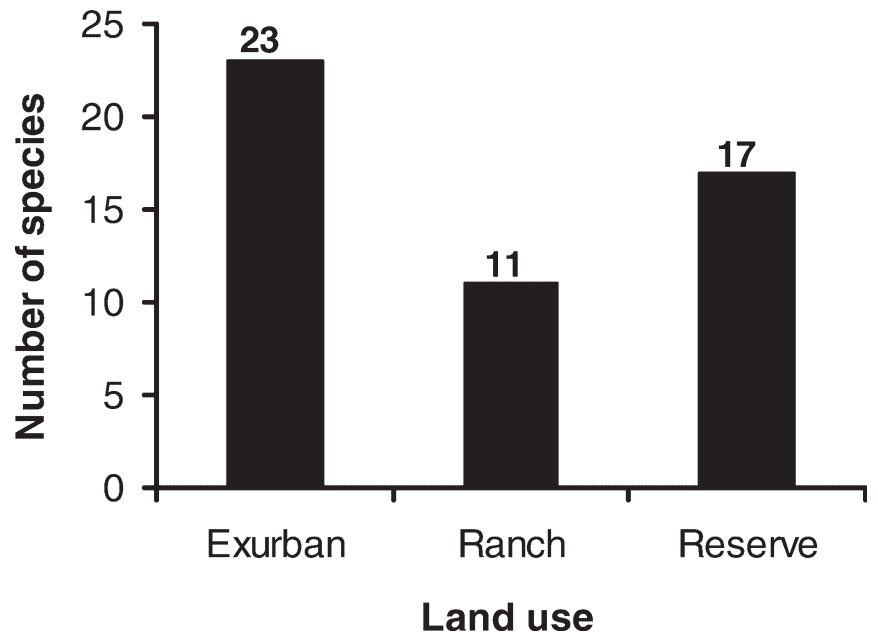

Figure 4. Cumulative number of nonnative plant species by land use. The same number of microplots $(n=276)$ were sampled on exurban developments, ranches, and reserves.

ungrazed areas on national forests in Colorado, Wyoming, Montana, and South Dakota. ${ }^{19}$ The exclosures averaged over 30 years without livestock (once more proving the benefit of having national parks, refuges, and other protected areas across the Western mosaic of landscapes).

The scientists found no differences between the grazed and ungrazed areas in a number of factors: plant species diversity; cover by grasses, forbs, and shrubs; soil texture; and the percentage of nitrogen and carbon in the soil. The authors concluded that:

1) grazing probably has little effect on native species
richness at landscape scales; 2) grazing probably has
little effect on the accelerated spread of most exotic plant
species at landscape scales; 3) grazing affects local plant
species and life-form composition and cover, but spatial
variation is considerable; 4) soil characteristics, climate,
and disturbances may have a greater effect on plant species
diversity than do current levels of grazing; and 5) few
plant species show consistent, directional responses to
grazing or cessation of grazing.

A word of caution regarding all of these findings. The West is not one place, but many places that grade into each other. They have different biological histories, and different ecological structures and functions, upon which cultural histories and landscape have been and are being superimposed. These regional and local differences in the ecology of the West have implications for grazing by domestic ungulates. Slope matters, as does elevation and aspect, and local rainfall. On a longer view, so does the post-Pleistocene environment in the presence of large, social ungulates: bison, elk, pronghorn. At a first approximation, then, some places should be more compatible with grazing by large, social, domestic ungulates than others. 
Grass and shrubs co-evolved with herbivores, species that grazed and browsed their new growth. The West has always been defined by large populations of herbivores, although the actual identity has changed over time. Whether it was mastodons and sloths, or bison and pronghorn, or grasshoppers and rodents, grass and shrubs need the stimulating disturbance brought about by large, blunt-ended incisors clipping their aboveground biomass, not to mention the dung and urine incorporated by hoof action facilitating more efficient nutrient cycling. Today the mastodons are gone and there are fewer bison and pronghorn than what had once occurred. And there are cattle, though not as many as we saw in the last century. But, we have learned that grazing by livestock, when appropriately done, contributes to the necessary disturbance that rangelands require. Perhaps we have come to the point where we measure land health premised on disturbance rather than just rest and realize there is no "balance of nature," but instead a "flux of nature." Getting the disturbance patterns right is the challenge. ${ }^{20}$

Nor are ranchers all one type. Ranching, done right, can coexist with healthy land or even restore land back to health. Done wrong, it can damage and destroy.

\section{Economics}

During a time when America's red ink is swelling large enough to swamp the world's largest economy, it is encouraging to realize that ranching tends to be fiscally responsible. On private lands ranching is far preferable to the "highest and best" alternative, exurban development. Study after study has reported the same finding: property taxes from rural residential developments come nowhere near paying the costs of county governments and school districts, whereas farming and ranching allow counties and schools to remain in the black. In Montana, for example, for each dollar of property taxes from ranchettes, counties and school districts, on average, have to ante up $\$ 1.45$ to meet these costs. ${ }^{21}$ On farms and ranches, however, they show a surplus, having to produce only $\$ 0.25$ of goods and services for every dollar of property taxes.

What about subsidized grazing on our nation's public lands? Ranchers are accused of feeding at the public trough. ${ }^{22}$ Wait a minute, what land use is not subsidized on our public lands? Indeed, outdoor recreation, our "highest and best use" is the most heavily supported public-land use with our tax dollars. This is appropriate, considering that all of us, ranchers included, recreate on public lands.

Importantly, however, the American public benefits from allowing ranchers to graze on America's public lands. It is estimated that the 21,000 ranch families that use approximately 30,000 grazing permits on BLM and USFS lands, own about 107 million acres of private land. ${ }^{23}$ Let me ask a question and you provide your own answer to this publicprivate policy issue. In your estimation, is it a fair bargain if over 100 million acres of ecologically-rich Western private lands are kept open and productive (the private half of the bargain), knowing that approximately $85 \%$ of federal lands are being grazed at some time of the year (the public half)? I am not sure how much the public values ranching, but, perhaps if they knew that by keeping private ranchlands out of development they are helping keep the West open and out of exurban development.

Another societal benefit from this public-private partnership between ranchers and our federal land agencies is the buffering effect of the private lands. Since our region is characterized by its blend of private and public lands, the spatial context of private ranchlands might be an indicator of their regional conservation value. In the Southern Rocky Mountain Ecoregion we evaluated this by comparing the relative proportion of the landscape comprised of private ranchlands between all private land in the study area with that component of the private land within $1 \mathrm{~km}$ of publicland grazing allotments. ${ }^{8}$ The privately owned grazing lands represent $21 \%$ of all private lands in this ecoregion. But if we just look at the private lands within $1 \mathrm{~km}$ of the public land grazing allotments, the proportion of private grazing lands increases to $43 \%$. This observation supports the notion that private ranchlands provide a land-use buffer around our public lands.

\section{Culture}

The West is a region of diverse ecosystems, cultures, and economies. Ranching as a land use, and ranchers as a culture have been with us for over 400 years, dating back to the early Spanish colonists who struggled northward over El Paso del Norte and found a home for their livestock near present-day Espanola, New Mexico. If what I have presented in this essay is true, that ranchers and ranching are disproportionately important to the ecology, economy, and culture of a West that works, then why are ranchers and ranching vilified? Consider this quote by a learned academic at a Western university:

The primary environmental objection to expanded residential activity is that subdivisions and urbanization damage the landscape in a variety of ways. But that is rarely an alternative use to which the land would be put. The appropriate comparison is between the environmental impact of ranching activity and that of residential use. We must put our agrarian sympathies aside: ranching does not step lightly on the land. ${ }^{24}$

Or this by Kieran Suckling of the Center for Biological Diversity:

Yes, we are destroying a way of life that goes back 100 years. But it's a way of life that is one of the most destructive in our county... Ranching is one of the most nibilistic life styles that the planet has ever seen. It should end. Good riddance. ${ }^{25}$ 
What does one say to such final pronouncements of cultural continuation? If ranching is to flourish, persist, or disappear in the West, it should be a conscious decision, based on informed discussions, not due to apathy or neglect. Or hate.

Perhaps these inflammatory statements are reflections of nothing more than different values. Might some Westerners want the public and private lands free of manure, cows, sheep, and fences because they want them for their own uses, such as mountain biking and river rafting? Do some want ranchers and their livestock off the Western ranges because they believe what others have told them-that cows and sheep sandblast land and that cattle barons are arrogant and intolerant of any but their own kind? Perhaps Americans are content to import their food from distant lands rather than have a more intimate association with the origin of their food.

My own sense is that differing values and distorted mythology can obscure facts, and that at the end of the day, emotion may trump judgment. Would it make any difference if we found that ranchers are stewards of the land; that cows are being used as a tool in the recovery of arid ecosystems; or that open space, biodiversity, and county coffers are enriched more from ranching than from the rapidly eclipsing alternative, ranchettes? Perhaps.

There are those who say the only difference between ranchers and realtors is a rancher is someone who hasn't sold his ranch yet. Do ranchers care for the land, or are they developers in sheep's clothing? Certainly there are quite a few that see their ranch as their last cash crop, their private $401 \mathrm{~K}$ account. On the other hand, mounting evidence suggests that ranchers care for the West's geography every bit as much as those of us in the cities and suburbs. In Colorado the state cattlemen's association has formed a land trust. To date, 150 conservation easements, totaling over 250,000 acres, have been entrusted to it from ranch families. Indeed, in Colorado, the cattlemen's land trust is second only to The Nature Conservancy in acres protected under conservation easements. Considering the economies associated with Western ranching, it is evident that today's ranchers are in it for its lifestyle attributes, far more so than as a way to reap great profits.

Western ranching has spanned the time scale from the First Americans to the astronauts, avoiding the moving-on mandate of the get-rich-quick industries of mining and logging. Charles Wilkinson, among the most distinguished of our region's scholars, had this to say about the region's ranchers and farmers:

Yet these industries are the foundation for local economies and provide food for the nation and the world. They preserve open space. As a culture, the people of the ranches and farms have settled in so deeply and for so long that for all practical purposes they are indigenous societies. ${ }^{26}$
In the heated arguments between ranchers and environmentalists, I will admit to coming down on the rancher's side. In our New West that is increasingly dominated by urban, suburban, and recently exurban Westerners, it occurs to me that perhaps we could settle the New West better than we conquered the Old West if we listened to the cultures that had been here before us (and that endure still). Might we have made a better place of this region if we had slowed down enough to listen to the First Americans? Did they have something to teach us about the region's wildlife, rivers and streams, grass and forests? In the words of Wendell Berry, "As important a reason as any to support ranching, farming, irrigating, and logging is that our society will need them as teachers, mentors, and critics in the years to come." ${ }^{27}$

So today, in our haste to remake ourselves once more into the Next West, might we avoid some mistakes if we showed respect to the ranching culture? A definitive answer to that question eludes me but my gut says yes, going slow and getting to know one's human and natural histories is essential to living well on a place.

\section{Conclusion}

Do ranchers, the noun, and ranching, the verb, qualify as keystone species based on their ecological, economic, and cultural importance? Ranch families working viable ranches that sustain ecosystem services and contribute to the social fabric and local economies are critical to a West that works. Ranchers, in addition to their other vital services, are an essential component to an intact rather than a subdivided West. Whether the land that is now in ranching remains in ranching or shifts to other uses, we are up against the same need: to keep this land unfragmented.

America is gradually waking up to one consequence of our globalizing economy; the loss of locally produced food on private lands that provide critical ecosystem services and open space. As ranching diminishes in the West and agricultural jobs move offshore, so too does the opportunity for our urban publics to reconnect with the rural tasks of husbanding food on well-stewarded land. ${ }^{1}$

Interestingly, these fragile relationships even relate to homeland security. When viewed in the light of rural and urban America, our government's concern over "Homeland Security" misses the most important point. A secure homeland is not simply based on military might. Home, land, and security blend together when urban people realize that ecologically sustainable food production is possible and that rural cultures matter, and when urban people are prepared to compensate farmers and ranchers for a healthy food product as well as for protecting open space, wildlife habitat, and watersheds. Gary Nabhan captured this when he wrote:

The simplest fact about Western ranches is the one most folks tend to forget: raising range-fed livestock is one of the few economic activities that produces food — and potentially 
ecosystem health and financial wealth-by keeping

landscapes relatively wild, diverse, and resilient. ${ }^{28}$

Imagine a time when Westerners eat locally produced food from private and public open spaces, offered and received with grace and a fair market value by urban people who no longer take for granted the societal services of local farmers and ranchers. Equally important to this winning equation are rural people who acknowledge the importance of urban areas and offer a friendly handshake to their urban neighbors. Perhaps to envision this, we need to remind ourselves that humans, whether rural or urban, can be keystone species or the ultimate weedy species, depending on their relationships to the land.

\section{Acknowledgments}

I thank Jim Thorpe, rancher, English major, and active participant in a West-that-works for his encouragement. Members and supporters of the Quivira Coalition (quiviracoalition.org) and the Malpai Borderlands Group (www. malpaiborderlandsgroup.org) have my deepest gratitude for making the "radical center" a safe harbor for those who emphasize communitarian rather than contrarian tendencies.

\section{References}

1. Knight, R. L. 2007. Bridging the great divide: reconnecting rural and urban communities in the New West. In L. Pritchett, R. L. Knight, and J. Lee [EDs.]. Home land: ranching and a West that works. Boulder, CO: Johnson Books. p. 13-25.

2. Riebsame, W. E. [ed.]. 1997. Atlas of the New West: Portrait of a changing region. New York, NY: W. W. Norton \& Co. $192 \mathrm{p}$.

3. Baron, J. S. [ED.]. 2002. Rocky Mountain futures: An ecological perspective. Washington, DC: Island Press. 325 p.

4. Garnsey, M. E. 1950. America's new frontier: The Mountain West. New York, NY: Alfred A. Knopf. 314 p.

5. Morgan, N. 1961. Westward tilt: The American West today. New York, NY: Random House. 411 p.

6. Knight, R. L., W. C. Gilgert, and E. Marston [eds.]. 2002. Ranching west of the 100th meridian: Culture, ecology, and economics. Washington, DC: Island Press. 259 p.

7. Sсотt, J. M., R. J. F. Аввiтt, and C. R. Groves. 2000. What are we protecting? The United States conservation portfolio. Conservation Biology in Practice 2:18-19.

8. Talbert, C. B., R. L. Knight, and J. F. Mitchell. 2007. Private ranchlands and public-land grazing in the Southern Rocky Mountains. Rangelands 29:5-8.

9. Losos, E., J. Hayes, A. Phillips, D. Wilcove, And C. Alkire. 1995. Taxpayer-subsidized resource extraction harms species. BioScience 45:446-455.

10. Czech, B., P. R. Krausman, and P. K. Devers. 2000. Economic associations among causes of species endangerment in the United States. BioScience 50:593-601.

11. Knight, R. L., And K. J. Gutzwiller [eds.]. 1995. Wildlife and recreationists: Coexistence through management and research. Washington, DC: Island Press. 372 p.
12. Mitchell, J. F., R. L. Knight, and R. J. Camp. 2002. Landscape attributes of subdivided ranches. Rangelands 24: 3-9.

13. Maestas, J. D., R. L. Knight, and W. C. Gilgert. 2003. Biodiversity across a rural land-use gradient. Conservation Biology 15:1143-1150.

14. Maestas, J. D., R. L. Knight, and W. C. Gilgert. 2002. Cows, condos, or neither: what's best for rangeland ecosystems? Rangelands 24:36-42.

15. Leopold, A. 1933. Game management. New York, NY: Charles Scribner's Sons. 481 p.

16. Hansen, A. J., R. Rasker, B. Maxwell, J. J. Rotella, J. D. Johnson, A. Wright Parmenter, U. Langner, W. B. Cohen, R. L. Lawrence, and M. R. V. Kraska. 2002. Ecological causes and consequences of demographic change in the New West. BioScience 52:151-162.

17. Hansen, A. J., R. L. Knight, J. Marzluff, S. Powell, K. Brown, P. H. Gude, and K. Jones. 2005. Effect of exurban development on biodiversity: patterns, mechanisms, and research needs. Ecological Applications 15:151-168.

18. Donahue, D. 1999. The Western Range revisited: Removing livestock from public lands to conserve nation biodiversity. Norman, OK: University of Oklahoma Press. 352 p.

19. Stohlgren, T 1999. How grazing and soil quality affect native and exotic plant diversity in Rocky Mountain grasslands. Ecological Applications 9:45-64.

20. Sayre, N. F. 2001. The new ranch handbook: A guide to restoring Western rangelands. Santa Fe, NM: The Quivira Coalition. 102 p.

21. Haggerty, M. 1996. Fiscal impact of different land uses on county government and school districts in Gallatin County, Montana. Bozeman, MT: Local Government Center, Montana State University. $42 \mathrm{p}$.

22. Wuerthner, G., and M. Matteson. 2002. Welfare ranching: The subsidized destruction of the American West. San Francisco, CA: Foundations for Deep Ecology. 368 p.

23. Gentner, B. J., and J. A. Tanaka. 2002. Classifying federal public land grazing permittees. Journal of Range Management 55:2-11.

24. Power, T. M. 1996. Lost landscapes and failed economies: The search for a value of place. Washington, DC: Island Press. 304 p.

25. Suckling, K. 1998. The Washington Post, February 1, p 55.

26. Wilkinson, C. 1989. The American West: A narrative bibliography and a study in regionalism. Niwot, CO: University Press of Colorado. $144 \mathrm{p}$.

27. Annual meeting of the Quivira Coalition, 2007, Albuquerque, NM.

28. Nabban, G. P. 2006. In praise, and in appraisal of, the working landscapes of the West. Quivira Coalition Journal 29:11-13.

Author is a professor of wildlife conservation in the Department of Forest, Rangeland, and Watershed Sterwardship, Colorado State University, Fort Collins, CO 80523, knight@cnr.colostate. edu. 


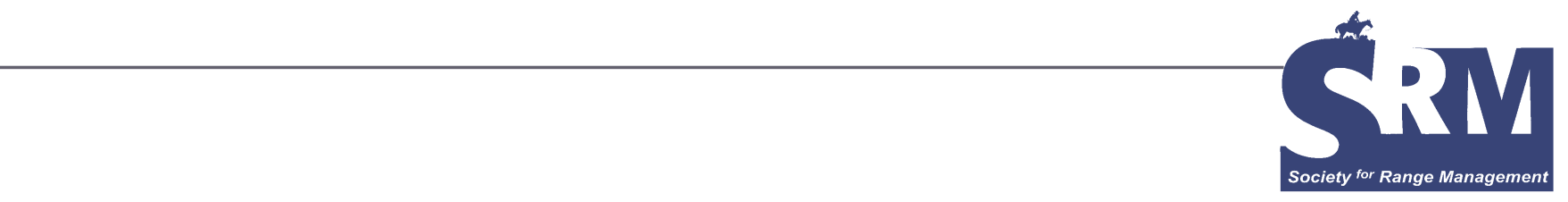

\section{Sculpting Brush Mechanically: Current State of the Art}

\section{By Harold T. Wiedemann}

Editor's Notes: Information in this article was previously published in Brush Management: Past, Present, and Future, Texas AE'M University Press, College Station, Texas, p. 33-46. Additional information about these and other types of equipment used on rangeland is described in the Revegetation Equipment Catalog available at http://reveg-catalog.tamu.edu.



rush-dominated rangelands occur over vast areas of Texas that were previously dominated by grasses. Coping with excessive tree and shrub cover has been a costly and often futile activity of ranchers for several decades. Historically, brush was viewed only as a nuisance to livestock production, and brush eradication was the prevailing management paradigm of many ranchers throughout the 1950s. Large-scale broadcast mechanical or chemical methods were applied over entire pastures or ranches. Maintenance of brush control and proper grazing management were not utilized; hence, many programs failed.

In the 1960s, it became apparent that brush eradication was neither physically possible nor economically feasible, so brush control became the prevailing philosophy. Management goals continued to be total eradication of targeted woody plants. Around 1975, the phrase "brush management" became more popular and reflected the idea that some woody plants had value. Wildlife in Texas was becoming more important as an economic entity during this time. In addition, environmentalists were starting to

Mention of a trade name is for identification only and does not imply an endorsement. call for a reduction in herbicide use. During the 1980s, stakeholders began to realize the value of addressing resource management practices simultaneously. This led to the development of integrated brush management. ${ }^{1}$

Range scientists, resource management agencies, and landowners are now recognizing that woody plants have both tangible and intrinsic values. This recognition, smallersized land holdings, and various other reasons, have brought about the current paradigm of brush sculpting. Brush sculpting is a concept in which brush-infested rangeland is sculpted for multiple uses, including wildlife and endangered species habitat, watershed management, recreation, and landscape enhancement, as well as traditional livestock grazing. ${ }^{2}$ These factors have influenced current mechanical brush control methods and devices in many ways. Each will be discussed.

\section{Selective Thinning}

Individual tree treatment is accomplished by grubbing or clipping and is an ideal method for sculpting brush-infested land. Sculpting can involve practices such as leaving islands of brush with connecting corridors to provide a safe habitat for wildlife and a protected pathway for their movement between sites, while cleared areas provide plants for grazing. Grubbing consists of belowground severing while clipping consists of aboveground severing. Grubbing equipment will be discussed first.

Mechanical grubbing is the severing of tree roots below ground by a sharp, U-shaped blade mounted on a tractor (Fig. 1). Tractors can be crawlers, wheel loaders (Fig. 2), or farm-type (Fig. 3) depending on the size of trees to be 


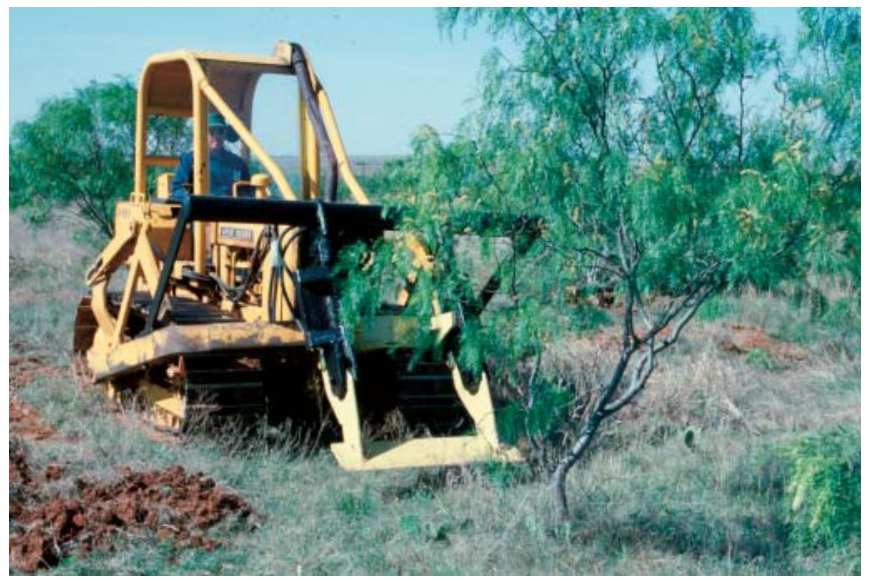

Figure 1. Low-energy grubber. ${ }^{6}$

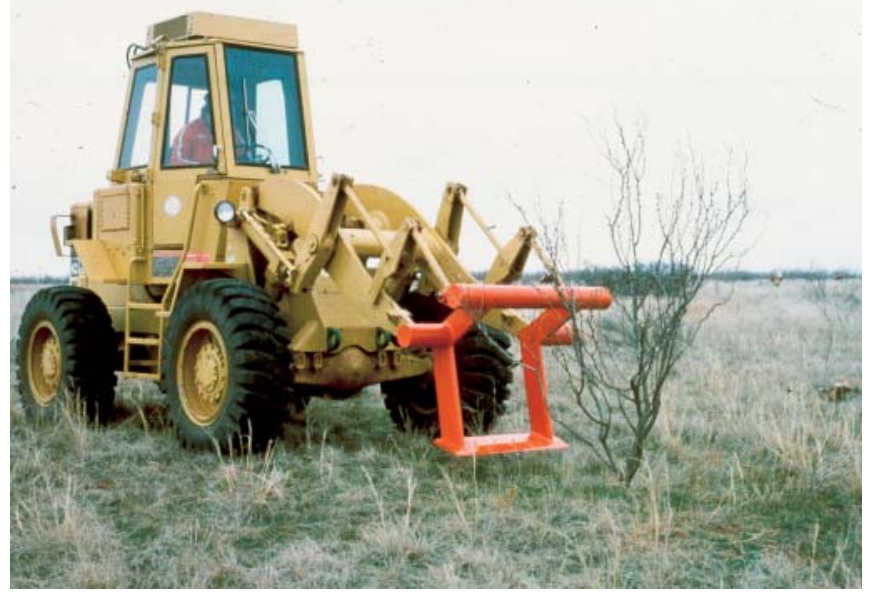

Figure 2. Wheel-loader grubber. ${ }^{4}$

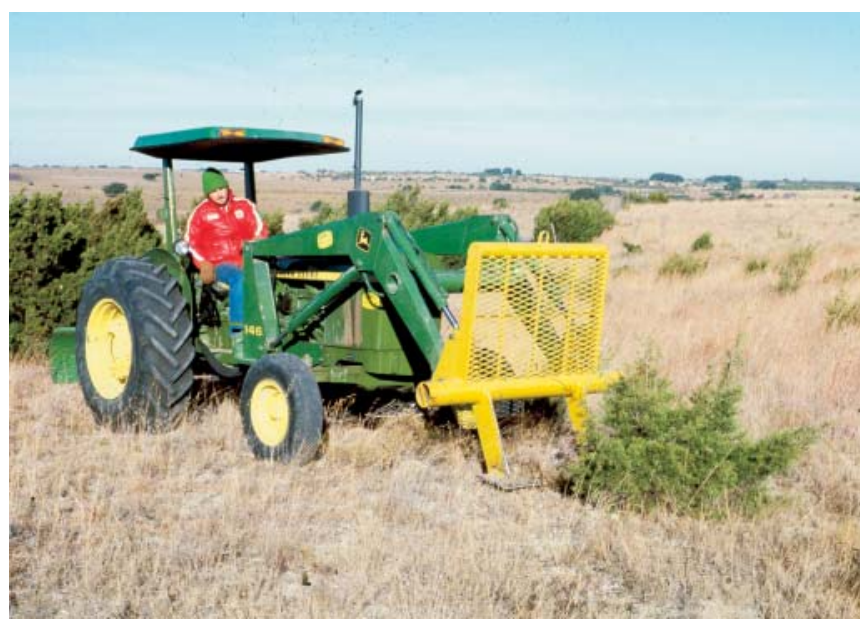

Figure 3. Farm-tractor grubber. ${ }^{4}$

grubbed and the type of terrain. Table 1 describes the best grubbing technique to achieve good plant root kills for various brush species in Texas. (A list of scientific names is provided in the appendix.)

\section{Table 1. Mechanical techniques to prevent the regrowth of 9 different brush species*}

\begin{tabular}{|c|c|}
\hline Species & Technique \\
\hline Mesquite & $\begin{array}{l}\text { Sever taproot below basal crown } \\
\text { (below bud zone), } 6-14 \text { inches deep, } \\
\text { depending on size of tree }\end{array}$ \\
\hline $\begin{array}{l}\text { Redberry } \\
\text { juniper }\end{array}$ & $\begin{array}{l}\text { Sever taproot below basal crown, } \\
6-12 \text { inches deep, depending on size } \\
\text { of tree }\end{array}$ \\
\hline $\begin{array}{l}\text { Ashe } \\
\text { (Blueberry) } \\
\text { juniper }\end{array}$ & $\begin{array}{l}\text { Sever trunk above or below ground } \\
\text { level, does not sprout from roots or } \\
\text { basal crown }\end{array}$ \\
\hline Algerita & $\begin{array}{l}\text { Remove basal crown and buried stems } \\
\text { under entire canopy area, } 4-6 \text { inches } \\
\text { depth }\end{array}$ \\
\hline Huisache & $\begin{array}{l}\text { Sever taproot below basal crown, } \\
6-12 \text { inches deep, depending on size } \\
\text { of tree }\end{array}$ \\
\hline $\begin{array}{l}\text { Twisted } \\
\text { acacia }\end{array}$ & $\begin{array}{l}\text { Remove as many as possible; sprouts } \\
\text { from roots }\end{array}$ \\
\hline Blackbrush & $\begin{array}{l}\text { Sever taproot below second lateral, } \\
6-12 \text { inches deep, depending on size } \\
\text { of tree }\end{array}$ \\
\hline Whitebrush & $\begin{array}{l}\text { Remove basal crown at depth of } 4-6 \\
\text { inches }\end{array}$ \\
\hline Catclaw & $\begin{array}{l}\text { Sever taproot below first lateral and } \\
\text { remove all buried stems with } \\
\text { adventitious roots }\end{array}$ \\
\hline
\end{tabular}

\section{Low-Energy Grubbing}

Low-energy grubbing uses a small tractor on small trees. This can be effective and cost efficient if tree densities are not too high. ${ }^{3}$ These tractors usually have hydraulically assisted blades that enhance performance by tearing roots loose as the blade is rotated. Table 2 presents the performance of a 65-horsepower crawler tractor with a hydraulicassisted blade (Fig. 1) grubbing 7 different brush species. Performance curves are shown in Figure 4. Grubbing rates vary due to tree size, density, distribution, soil moisture, and type of terrain. Grubbing is best suited to tree infestations of 25-250 trees $\cdot$ acre $^{-1}$.

Research involving the use of hydraulic force to assist in uprooting trees was started in the early 1970 s. $^{3}$ Supplementing tree-uprooting forces with hydraulics allowed smaller, less costly tractors to be utilized. The result was the low-energy grubber. Tractor sales and grubber construction averaged over $\$ 1$ million $\cdot \mathrm{yr}^{-1}$ for 5 years in the late 1970s. The concept of hydraulic assistance has spawned a niche industry in Texas that markets novel grubbers for small tractors. 
Table 2. Efficacy of the low-energy grubber (Fig. 1) operating in 7 different brush species*

\begin{tabular}{|c|c|c|c|}
\hline Species & $\begin{array}{c}\% \text { plant } \\
\text { kill }\end{array}$ & Trees $\cdot$ acre $^{-1}$ & Dollars $\cdot$ acre $^{-1 * *}$ \\
\hline Mesquite & 80 & $20-100$ & $3.00-12.00$ \\
\hline Juniper & 98 & $30-175$ & $4.50-27.00$ \\
\hline Huisache & 75 & $75-225$ & $9.50-30.00$ \\
\hline Algerita & 93 & $15-80$ & $5.50-16.50$ \\
\hline $\begin{array}{l}\text { Twisted } \\
\text { acacia }\end{array}$ & 0 & $30-250$ & $3.50-16.00$ \\
\hline Blackbrush & 86 & $20-130$ & $6.50-19.00$ \\
\hline Catclaw & 85 & $50-150$ & $8.50-20.50$ \\
\hline
\end{tabular}

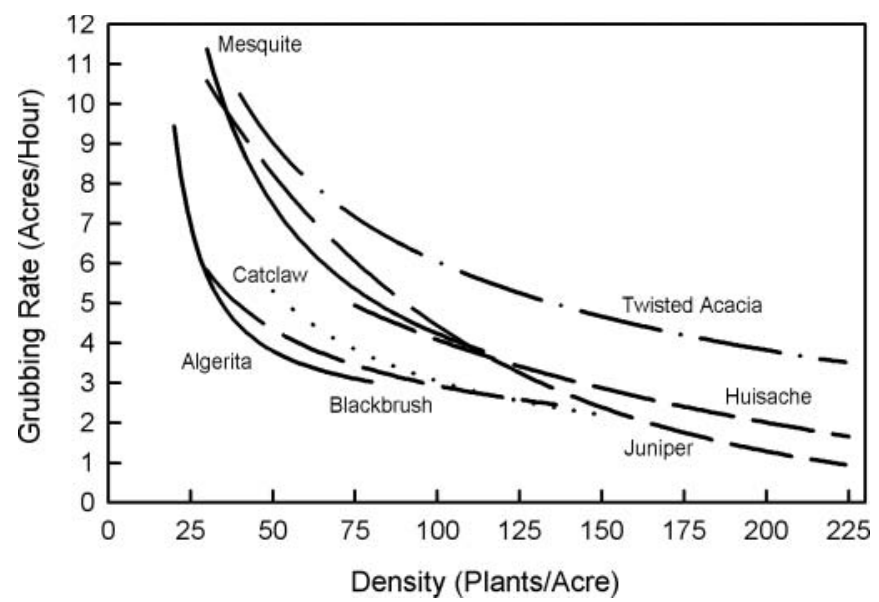

Figure 4. Performance curves for a 65-horsepower crawler tractor grubbing 7 brush species. A field-efficiency factor of $70 \%-85 \%$ should be anticipated.

\section{Loaders}

With the advent of foam filling of off-road tires, the use of rubber-tired equipment on thorn-infested rangeland became practical. ${ }^{4}$ Wheeled loaders are especially useful for grubbing (Fig. 2) because they provide excellent vision for the operator, they can travel on roads between sites, and the bucket can be useful for material-handling jobs. Crawler tractors have to be hauled between sites. Performance of a wheeled loader in mesquite (Prosopis glandulosa var. glandulosa) regrowth 10 years following rootplowing is shown in Figure 5. In a grubbing comparison between a loader (Fig. 2) and crawler tractor of equal size ( 80 horsepower), the loader had 38\% less soil disturbance and $43 \%$ less fuel consumption than the crawler. Productivity of the loader was the same as the crawler at a density of

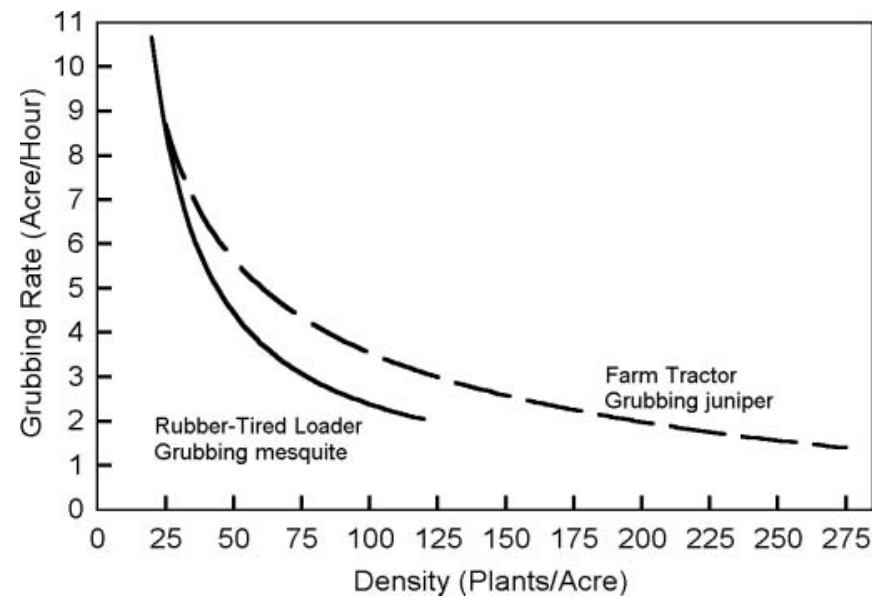

Figure 5. Performance curves for a wheeled loader grubbing mesquite 2-6 feet tall and for a farm tractor grubbing junipers $2-4$ feet tall.

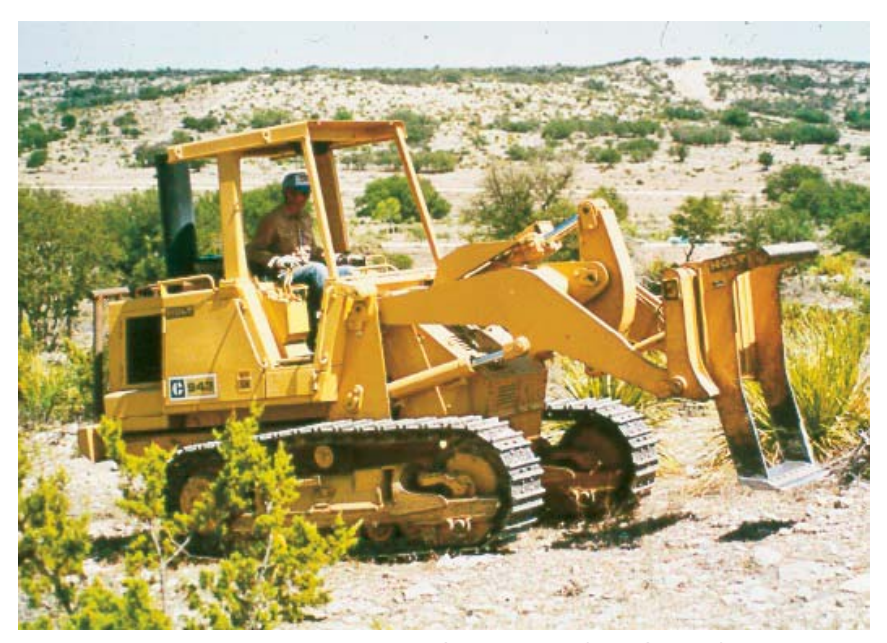

Figure 6. Track-loader grubber. Courtesy HOLT-CAT, San Antonio, Texas.

19 trees $\cdot$ acre $^{-1}$ but $42 \%$ less than the crawler at a density of 140 trees $\cdot$ acre $^{-1}$.

Farm tractors with front-end loaders are handy for grubbing juvenile trees (Fig. 3), and performance on small junipers (Juniperus spp.) is shown in Figure 5. Track-type loaders are also practical for grubbing because the forward location of the cab provides the operator with a good view of the grubbing blade and the small cleats on the track grouser allow minimum soil disturbance (Fig. 6).

\section{Three-Point-Hitch Grubbers}

A popular method for grubbing limited acreage of small trees uses a three-point-hitch grubber on the rear of a farm tractor. Some grubber styles require the tractor to drive over the tree first while others back the tractor to the tree and use the three-point hitch to lift the tree from the soil (Fig. 7). Grubbing trees by backing into them had an average rate of 155 mesquites $\cdot h^{-1},{ }^{5}$ while grubbing with frontmounted units on a crawler averaged 288 mesquites $\cdot \mathrm{h}^{-1}$ and 432 small junipers $\cdot h^{-1} \cdot 3,6$ 




Figure 7. Three-point-hitch grubber. Courtesy Harold Wiedemann.

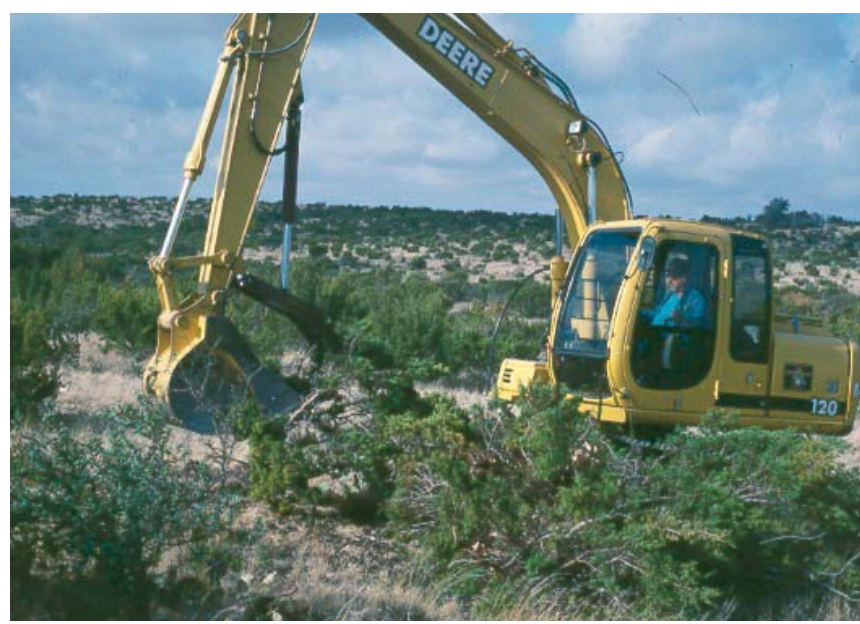

Figure 8. Excavator grubber. Courtesy Darrell Ueckert, San Angelo, Texas.

\section{Excavators}

The most recent addition to the list of grubbers is the excavator. Excavators are track-type, high-capacity backhoes that are front-mounted (Fig. 8). With the boom extended, they can work a 50 -foot swath while moving in a straight line. The bucket, equipped with rock-digging teeth and a two-prong clamshell clamp, is very effective for removing junipers from rocky soil and stacking them. A U-shaped grubbing blade can be used in place of the bucket. Observations by scientists estimate a grubbing rate of 200-500 trees $\cdot h^{-1}$. Excavators have air-conditioned cabs, "joystick" controls, and small cleats on the track grousers that enhance the their smooth operation.

\section{Skid-Steer Loaders}

Brush species, such as Ashe juniper (Juniperus ashei), which do not sprout from the roots, can be clipped above ground rather than uprooted below ground. Skid-steer loaders accomplish this using hydraulic shears (Fig. 9). Because of availability and low cost, they have become popular in sculpting landscapes. When shearing sprouting species (mesquite and redberry junipers [Juniperus pinchotii]), some contractors spray the stump with herbicide to reduce regrowth. ${ }^{7}$

\section{Selective Clearing}

Selective clearing implies that selected areas are cleared of all woody species, leaving a mosaic pattern or strips of cleared areas within the brushy landscape. The cleared areas should be seeded with native or introduced grasses and shrubs that meet multiple-use goals. Treatments can involve removing all aboveground growth, severing all roots at a given depth, or removing root systems from the soil. Clearing usually involves a combination of methods. The current machines used and their application are discussed in this section.

\section{Chains}

Ship-anchor chain pulled between two crawler tractors is widely used for tree felling because it can open an area quickly and is low in cost. Chains vary in length from 200 to 400 feet, weigh $40-75$ pounds $\cdot$ foot $^{-1}$, and are pulled in a U-shape. Chaining is used in moderately dense to dense stands of trees (trunk diameters $>3$ inches) and is most effective for uprooting when soil moisture is high. It is not effective on shrubs or small trees with limber stems. Effectiveness is short-lived because of regrowth, and chaining should be used in combination with other treatments for maximum effectiveness. In north Texas, mesquite is chained 2-3 years following aerial spraying, while in south



Figure 9. Skid-steer loader with shears. Courtesy Darrell Ueckert, San Angelo, Texas. 
Texas dense stands of mixed brush are chained and stacked prior to subsequent treatments. ${ }^{8}$

\section{Modified Chains}

Modification of an anchor chain can be made by adding a device to enhance the performance of the chain for brush manipulation and/or seedbed preparation. Examples follow.

Elevated chains. In individual tree tests, an elevated striking height reduced felling force by $67 \%$ compared to ground level striking on Ashe juniper in southern Oklahoma and by $84 \%$ on redberry juniper in north Texas. ${ }^{9,10}$ Elevated chaining is accomplished by attaching a rotating ball in the center of the chain pulled by two crawler tractors (Fig. 10). This one-way chaining method, if followed by prescribed burning, can achieve $98 \%$ eradication of Ashe juniper. The chain-burn strategy tested on redberry juniper, a sprouting species, did not improve eradication rates over chaining alone mainly because herbaceous fuel was uneven, and when burned it did not supply sufficient heat to burn the exposed stumps. ${ }^{11}$ A 4 -foot-diameter ball worked best in junipers that were 9-18 feet tall, and a 6-foot ball was more effective in trees that were $18-45$ feet tall. ${ }^{10}$

Disk-chain-diker. A unique tool developed mainly for seedbed preparation on debris-littered land, but also used for limited brush control, is the disk-chain-diker (Fig. 11). Although it was designed to follow rootplowing, it can also be used on undisturbed sites when shrubs are $<8$ feet tall. The disk-chain-diker tills, smoothes, and forms small basins in the soil all in one pass and is energy efficient. ${ }^{12} \mathrm{~A}$ disk chain is an anchor chain with disk blades welded to alternate chain links. Disking action occurs when the chain, with swivels attached to each end, rotates as it is pulled diagonally. A flexing roller holds the disk-chain gangs in place. The chain diker, which is attached to the rear of the roller, uses specially shaped blades welded to opposing sides of each link of a large anchor chain. As it is pulled over tilled land, the chain rotates and the blades leave a broadcast

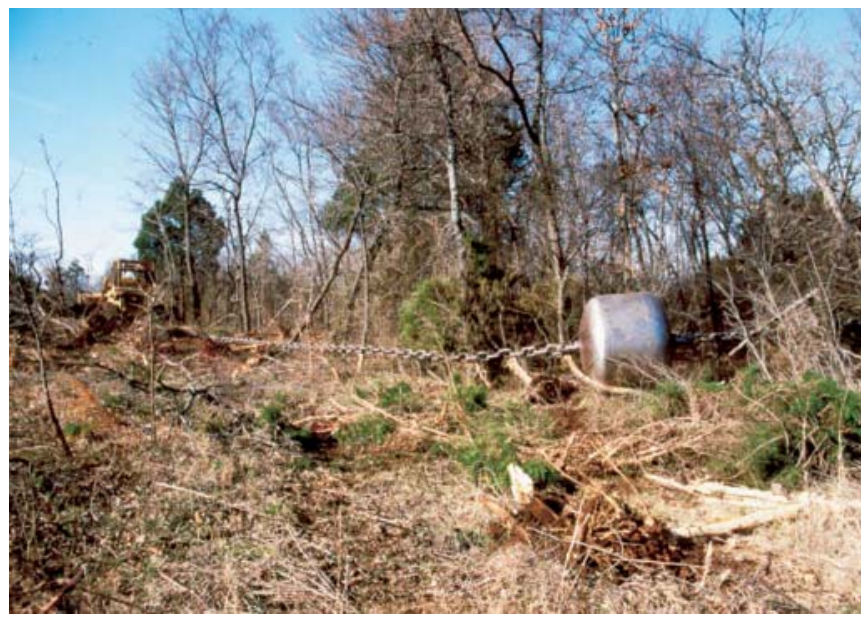

Figure 10. Elevated chain. Courtesy Harold Wiedemann.

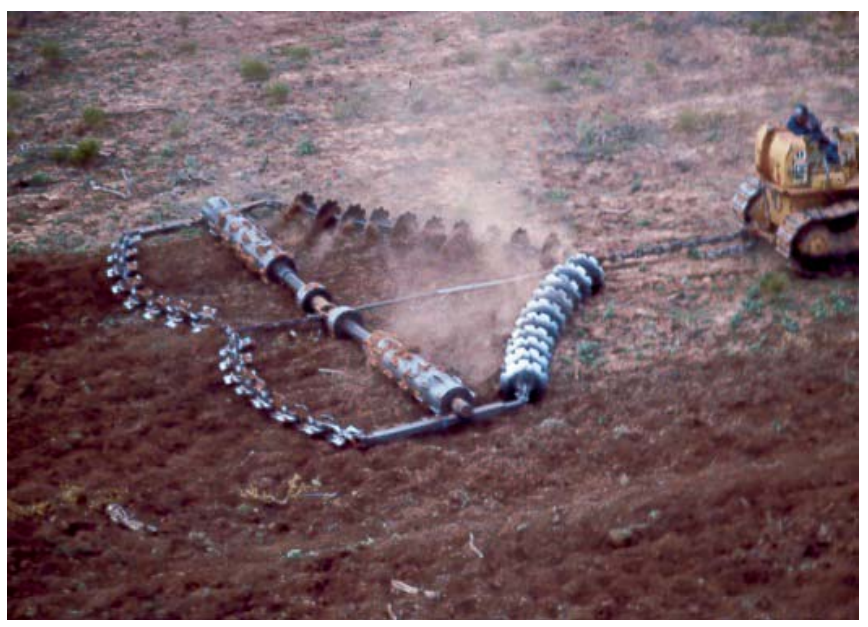

Figure 11. Disk-chain-diker. ${ }^{13}$

pattern of diamond-shaped basins 4 inches deep. Pulling requirements depend on the size of each component; a standard-sized unit requires a force of 515 pounds $\cdot$ blade $^{-1}$ and 20 blades are usually used. A 20-blade unit is 35 feet wide and requires a 165-200-horsepower crawler tractor for pulling. A detailed explanation of the unit is provided by Wiedemann. ${ }^{13}$

In seeding studies over a 3-year period, grass densities were increased 92\% when the disk-chain diker was used, compared to seedbeds prepared by using smooth chain in clay-loam soil. There was no significant difference in grass densities between seedbeds prepared by disk chaining or offset disking, but both were significantly higher than chaining alone. ${ }^{14}$ Basins prepared by the chain diker increased grass stands from $33 \%$ to 2.6 times the density of grass stands on non-diked areas when growing-season rainfall was $<20$ inches. ${ }^{15}$ Diking provided no advantage when growing-season rainfall was $>20$ inches. Since much of western Texas receives $<20$ inches of rainfall, it would be advantageous in many areas to include chain diking as part of seedbed preparation for rangeland seeding. Chain diking reduced runoff by $40 \%$ compared with non-diked treatments over a 3 -year period on a slope of $0.3 \%{ }^{16}$

\section{Rootplows}

A rootplow is a heavy-duty, V-shaped, 10-16-foot-wide horizontal blade pulled by a large crawler tractor at a depth of 12-14 inches (Fig. 12). This operation severs roots, preventing regrowth of nearly all brush species except those with shallow root systems such as whitebrush (Aloysia gratissima) and prickleypear cacti (Opuntia spp.). Chaining or raking following plowing helps to smooth the soil surface and remove sprouting species or stumps. Rootplows have been in use since the 1940s to clear dense stands of mesquite and other hard-to-kill brush species in preparation for seeding grasses or crops. ${ }^{8}$ The commercial rootplowing rate averages approximately 2 acres $\cdot \mathrm{h}^{-1}$. Sculpting densely 


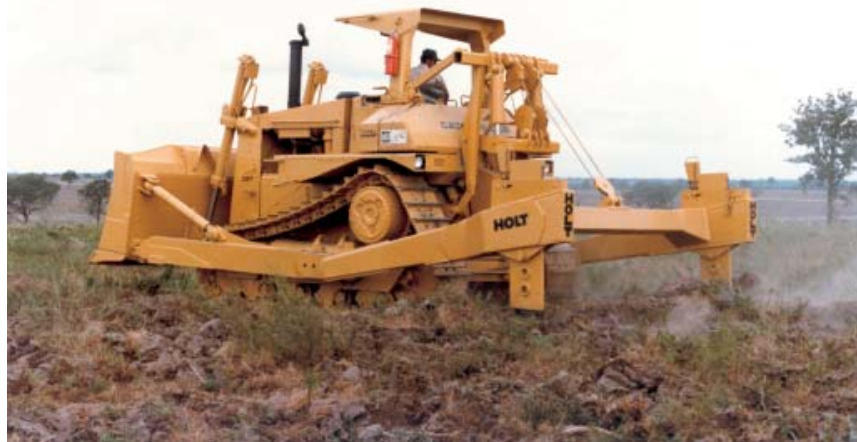

Figure 12. Rootplow. Courtesy HOLT-CAT, San Antonio, Texas.

brush-infested areas by selective plowing followed by seeding with plants favorable for wildlife habitat, grazing animals, and watershed management could enhance the multiple-use value of depleted rangeland on fertile soils. The most recent change in rootplows has been the development of regrowth plows.

\section{Regrowth Rootplows}

Holt Company of Texas (changed to HOLT CAT in 2002) has started manufacturing a line of regrowth plows (Fig. 13) and rakes for areas where brush regrowth occurs on land previously cleared with conventional rootplows. They are especially useful in coastal bermudagrass (Cynodon dactylon) pastures in parts of south Texas. Performance is best when tree-trunk diameters are $\leq 4$ inches. The plows resemble conventional rootplows but have been downsized to fit Caterpillar D-6 crawlers, rubber-tracked Challengers, or large farm tractors. ${ }^{17}$ These 10 -foot-wide units use quick hitches and are much more energy efficient and cost effective than conventional rootplows.

The regrowth root rake has been designed to operate in concert with the regrowth plow. These 14-foot-wide units remove roots from the soil and pile them along with any

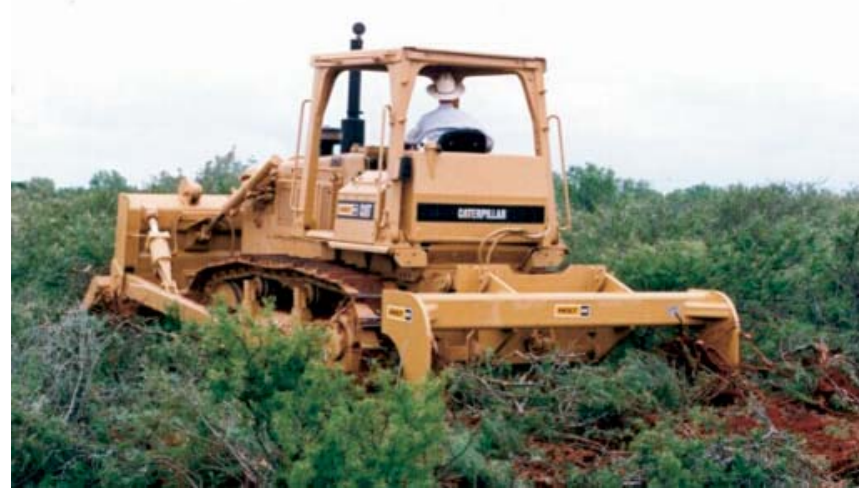

Figure 13. Regrowth plow. Courtesy HOLT-CAT, San Antonio, Texas. aboveground brush debris. ${ }^{17}$ They use the same quick hitch as the regrowth plows.

\section{Renovators/Aerators}

Roller chopping of brush has been accomplished using a large, rotating drum with a series of longitudinally mounted blades. A recent advancement in roller choppers is the use of small blades welded to the heavy drums in a staggered, cylindrical pattern; these units are called renovators or aerators (Fig. 14). ${ }^{18}$ The advantages of the renovators are that the small blades chop debris and form basins in the soil to capture and hold rainfall. In addition, the staggered, cylindrical blade pattern prevents the vibration caused by the longitudinal blade placement on standard-roller choppers. Renovators normally use 2 drums mounted on a frame similar to an offset disk and are pulled with a crawler tractor or specially equipped, rubber-tired tractor. The drum diameters vary from 18 to 42 inches and can be filled with water for added weight. Renovators are used in moderate to dense shrub-infested rangeland or pastures to remove the top growth of shrubs and to improve rainfall retention. Removal of the top growth produces a flush of regrowth. This is desirable for browsing animals when used on palatable brush species such as Bigelow shin oak (Quercus durandii var. breviloba) or guajillo (Acacia berlandieri). When seeding grass in combination with chopping, the basins enhance seedbed preparation. The rate of roller chopping on Bigelow shin oak averaged 5.3 acres $\cdot \mathrm{h}^{-1}$ using a 15 -foot-wide drum filled with water. ${ }^{19}$

\section{Disks}

Disks used on rangeland are the heavy-duty offset style. Blade diameters range from 24 to 36 inches and units are 8 to 12 feet in width. Disks with 36 -inch blades are used for brush control on undisturbed soil, while units with blade diameters $<30$ inches are used for seedbed preparation following rootplowing. Whitebrush was controlled by disking in the fall (13\% mortality) and then re-disking

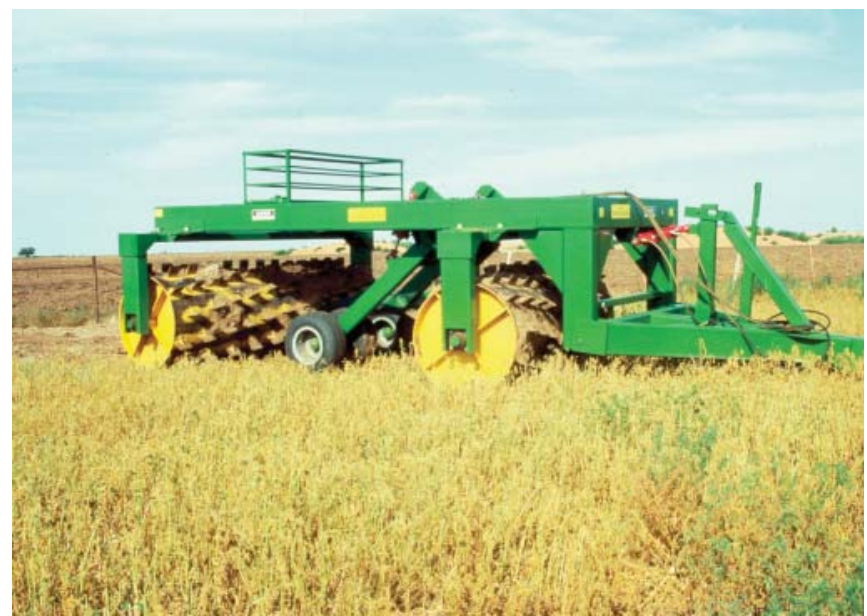

Figure 14. Renovator/aerator. Courtesy Harold Wiedemann. 


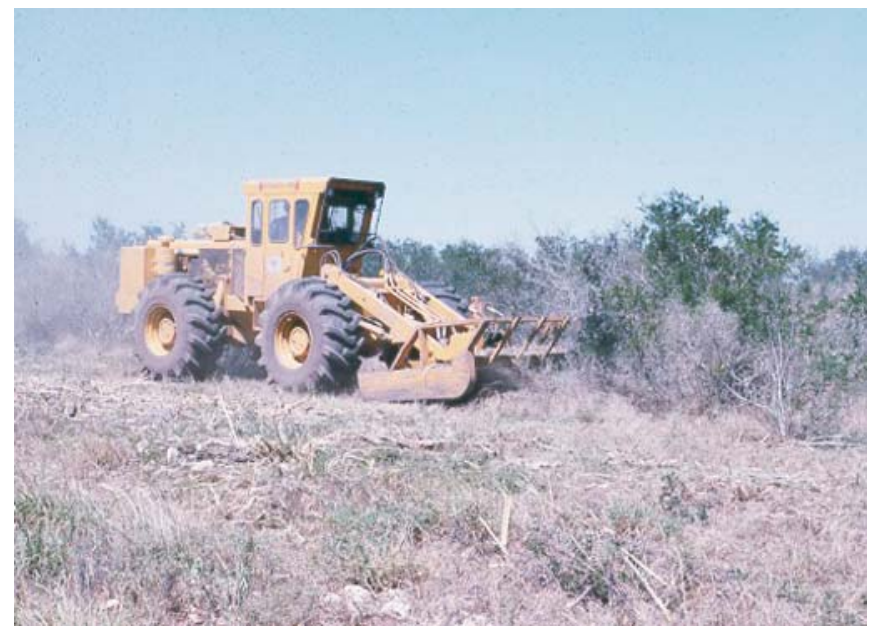

Figure 15. Self-propelled shredder. Courtesy Harold Wiedemann.

in the spring after the root crowns had sprouted (91\% mortality). ${ }^{20}$ Oats (Avena spp.) were seeded following fall disking and buffelgrass (Cenchrus ciliaris) was seeded following spring disking for livestock grazing. Seedbeds prepared by disking (24-inch blades) consistently produced better grass stands than did roller chopping or chaining on rootplowed sites at 9 locations in the Edwards Plateau and Rolling Plains. ${ }^{21}$ If excessive timber prevents the use of a disk, then a disk-chain-diker can be used.

\section{Shredders}

Brush shredders are patterned after pasture and crop shredders but are designed to withstand more strain. Their width is normally 7 feet, but selected units are 15 feet wide. Brush shredding is prone to mechanical failures and usually requires extensive modification of the farm tractor that pulls the unit. Modifications include foam filling of the tires or other approaches to prevent flats and mounting front and bellypan guards as well as a rear guard to protect the back of the operator from flying debris. Shredding brush leaves the plant height level, and this is aesthetically pleasing. Regrowth, however, is extensive following shredding of all sprouting shrubs. Mechanical downtime was $64 \%$ when shredding Bigelow shin oak with a standard 7-foot shredder in the Edwards Plateau. ${ }^{19}$ Shredders are more applicable for pasture weed control than brush control, but they can be used on brush over limited acreage.

Self-propelled shredders are constructed for brush mastication, and a Hydro-Ax unit was very effective in removing top-growth of Bigelow shin oak at a rate of 2.35 acres $\cdot h^{-1}$ (Fig. 15). However, they are expensive and not readily available.

\section{Summary}

Sculpting brush-dominated rangeland for multiple use has resulted in new opportunities for mechanical brush control methods. Managing brush infestations for better wildlife habitat, watershed management, and recreation enterprises often benefits from mechanical manipulation. This fact, coupled with new advancements in machines and methods in which they are used, has helped to establish mechanical brush control as a viable option in brush management. Costs are increasing in all phases of brush management, and currently, one may experience contractors adding fuel surcharges to their equipment costs.

\section{References}

1. Hamilton, W. T. 1985. Initiating IBMS. In: C. J. Scifres, W. T. Hamilton, J. R. Conner, J. M. Inglis, G. A. Rasmussen, R. P. Smith, J. W. Stuth, and T. G. Welch [eds.]. Integrated brush management systems for south Texas: development and implementation. Texas Agricultural Experiment Station Bulletin 1493:9-14.

2. Wiedemann, H. T., D. Rollins, D. N. Ueckert, and A. McGinty. 1999. Sculpting brush-dominated rangeland for multiple use. In: D. Eldridge and D. Freudenberger [eds.]. Proceedings of the VI International Rangeland Congress; 19-23 July 1999; Townsville, Queensland, Australia. p. 233234.

3. Wiedemann, H. T., B. T. Cross, and C. E. Fisher. 1977. Low-energy grubber for controlling brush. Transactions of the ASAE 20(2):210-214.

4. Wiedemann, H. T., and B. T. Cross. 1982. Performance of front-mounted grubber on rubber tired equipment. PR-3982:50-53. In: Texas Agricultural Experiment Station CPR-3968-4014.

5. McFarland, M. L., and D. N. Ueckert. 1982. Mesquite control: use of a three-point hitch mounted, hydraulically assisted grubber. PR-3981:48-50. In: Texas Agricultural Experiment Station. CPR-3968-4014.

6. Wiedemann, H. T., and B. T. Cross. 1981. Low-energy grubbing for control of junipers. Journal of Range Management 34(3):235-237.

7. McGinty, A., And D. N. Ueckert. 1997. Brush busters: how to beat mesquite. Texas Agricultural Extension Service \& Texas Agricultural Experiment Station. Leaflet L-5144.

8. Fisher, C. E., H. T. Wiedemann, C. H. Meadors, AND J. H. BRock. 1973. Mechanical control of mesquite. Texas Agricultural Experiment Station Research Monograph $1: 46-52$.

9. Wiedemann, H. T., And B. T. Cross. 1996a. Draft requirements to fell junipers. Journal of Range Management 49(2): 174-178.

10. Wiedemann, H. T., and B. T. Cross. 1996b. Draft requirements for tree felling by chaining. St. Joseph, MI: American Society of Agricultural Engineers. Paper No. 965003.12 p.

11. Ansley, R. J., H. T. Wiedemann, M. J. Castellano, and J. E. Slosser. 2006. Herbaceous restoration of juniper dominated grasslands with chaining and fire. Rangeland Ecology and Management 59:171-178.

12. Wiedemann, H. T., and B. T. Cross. 1994. Chain diker draft and power requirement. Transactions of the ASAE 37(2): 389-393.

13. Wiedemann, H. T. 1990. Disk-chain-diker implement selection and construction. Vernon, TX: Chillicothe-Vernon Agricultural Research and Extension Center. Center Technical Report No. 90-1. 19 p. 
14. Wiedemann, H. T., and B. T. Cross. 2000. Disk chain effects on seeded grass establishment. Journal of Range Management 53(1):62-67.

15. Wiedemann, H. T., and B. T. Cross. 2001. Chain diker effects on seeded grass establishment following disk chaining. Journal of Range Management 54(2):138-143.

16. Wiedemann, H. T., and L. E. Clark. 1996. Chain diking effects on runoff and winter wheat yield. Agronomy Journal 88:541-544.

17. Holt Company of Texas. 1997. Product literature. San Antonio, TX.

18. Lawson Cattle and Equipment, Inc. 1994. Pasture aerator product literature. Kissimmee, FL.

19. Wiedemann, H. T., C. H. Meadors, and C. E. Fisher. 1980. Bigelow shin oak control. Texas Agricultural Experiment Station. CPR-3665:28-29.

20. Wiedemann, H. T., and B. T. Cross. 1980. Evaluation of equipment for control of whitebrush. Texas Agricultural Experiment Station. CPR-3665:101-102.

21. Wiedemann, H. T., J. H. Brock, C. E. Fisher, and B. T. Cross. 1979. Seed metering and placement devices for rangeland seeder. Transactions of the ASAE 22(5):972-977.

22. Wiedemann, H. T. 1997. Factors to consider when sculpting brush: mechanical treatment options. In: D. Rollins, D. N. Ueckert, and C. G. Brown [eds.]. Proceedings of Brush Sculptors Symposium; 21-22 August, Uvalde, TX; and 17-18 September, Abilene, TX. San Angelo, TX: Texas Agricultural Extension Service. p. 88-95.

Author is Professor Emeritus, Texas AEMM University, 4000 Stony Creek Lane, College Station, TX 77845, h.wiedemann@ verizon.net.
Appendix. Common and scientific names of plants

\begin{tabular}{|c|c|}
\hline Common name & Scientific name \\
\hline Mesquite & $\begin{array}{l}\text { Prosopis glandulosa var. } \\
\text { glandulosa }\end{array}$ \\
\hline Junipers & Juniperus spp. \\
\hline Redberry juniper & Juniperus pinchotii \\
\hline Ashe juniper & Juniperus ashei \\
\hline Algerita & Berberis trifoliolata \\
\hline Huisache & Acacia smallii \\
\hline Twisted acacia & Acacia tortuosa \\
\hline Blackbrush & Acacia rigidula \\
\hline Whitebrush & Aloysia gratissima \\
\hline Catclaw & Acacia greggii \\
\hline Prickleypear cacti & Opuntia spp. \\
\hline Bigelow shin oak & Quercus durandii var. breviloba \\
\hline Guajillo & Acacia berlandieri \\
\hline Coastal bermudagrass & Cynodon dactylon \\
\hline Wheat & Triticum aestivum \\
\hline Oats & Avena spp. \\
\hline Buffelgrass & Cenchrus ciliaris \\
\hline
\end{tabular}




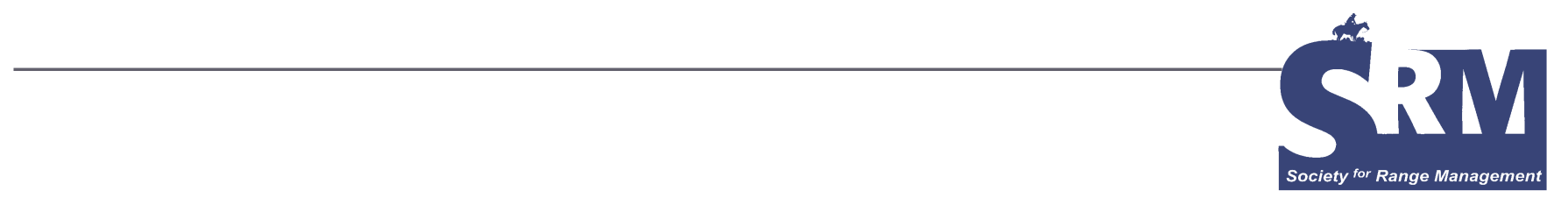

\section{Planned Herbivory in the Management of Wildfire Fuels}

\section{Grazing is most effective at treating smaller diameter live fuels that can greatly impact the rate of spread of a fire along with the flame height.}

\section{By Glenn Nader, Zalmen Henkin, Ed Smith, Roger Ingram, and Nelmy Narvaez}

W

ildfires are increasing in number, intensity, and size. Five of the most significant wildfire seasons in the United States since 1960 , as measured by total acres burned, have occurred since $2000 .{ }^{1}$ The vegetation or fuel profile, a major factor determining fire behavior, is studied in two aspects: vertical and horizontal arrangement, and amount. The vertical arrangement of fuel determines the degree of its mixture with air and, thus, flame height and duration of elevated heat. The continuity of horizontal fuel arrangement determines potential for fire spread across the landscape. These attributes, along with topography and weather conditions (wind and fuel moisture), are what determine the kind of wildfire that is going to occur. Many management and ecological conditions have allowed for the increased fuels. The increasing number of residences being built in forest and rangeland ecosystems provides more ignition sources and restricts the ability to manage fire. Introduction of exotic plants such as cheatgrass also has changed the fire behavior in many sagebrush plant communities. ${ }^{2}$

Fuel treatments are generally placed in two different categories. Fuel breaks are linear fuel modifications that are often situated along a road or ridge. They can range in width from 30 feet to 400 feet and are designed as a tool for fire fighters to stop fires. Landscape area treatments are designed to reduce flame height and change fire behavior over a large area. Long-term landscape treatment efforts are focused on changing the plant community to decrease the flame height when fire occurs. Both approaches require maintenance in order to remain valuable fire management tools. The objective for fuel reduction is to change fire behavior by impacting the following: fuel bed depth, fuel loading, percent cover, and ladder fuels that result in a fire flame less than four feet high. At that level all fire fighting management tools can be used, while maintaining fire fighter safety.

\section{Mechanized Treatments}

Mechanized treatments are used by land managers to alter or remove vegetation, including mowing, mastication, and biomass harvesting. Mastication involves the use of a large mechanized device for chopping, and is used in brush and trees to break up the fuel pattern and decrease combustibility by placing fuels on the ground. It changes fire behavior by rearranging the fuel profile through distributing some of the fuel on the ground. This action also causes a reduction of ladder fuels, which decreases potential for vertical extension of fire into tree canopies; crown fires are very difficult for fire fighters to control. Mastication can be used as a pretreatment followed by prescribed fire or grazing treatments. Some of the disadvantages of mastication are the cost of $\$ 350$ to $\$ 800$ per acre, ground disturbance, short life of the treatment in some areas, terrain and surface roughness limitations, and soil compaction. Mastication can 
result in death in some brush species, but many species resprout from the roots and require retreatment. Mechanized treatments also include the thinning of overstory vegetation through biomass harvesting. The harvested biomass is brought to a chipping unit and the resulting material is transported off the site for use in energy power plants. The sale of the biomass chips reduces the cost of this treatment. Thinning can provide desired conditions for both ladder fuels and crown spacing in one treatment. Soil moisture condition is the only limitation on the time of year that the treatment can be conducted. Disadvantages include transportation costs of hauling biomass and removal of nutrients from the ecosystem. In some cases, trees that are removed can be sold as commercial saw logs to offset fuel treatment costs. Mowing is generally used in grass communities to drop the fuel on the ground, where it has less contact with air and thus has lower combustibility. Mowing needs to be done during the end of the green season or it can cause fires from the blades striking rocks when dry grass is present. The costs of mowing range from $\$ 25$ to $\$ 40$ per acre.

\section{Herbicides}

Herbicides can be sprayed to kill specific plants, but this does not alter the fuel pattern immediately. Herbicide treatment of targeted species has a cost of $\$ 25$ to $\$ 250$ per acre. The disadvantages include concerns about its impact on the environment and short-term increases in fuel flammability.

\section{Prescribed Fire}

Prescribed fire can be used to change the fuel load and pattern. Prescribed burning can generally be achieved for less than $\$ 150$ per acre. It is most effective for reducing surface fuels 0-3 inches in stem diameter. Because of air quality concerns and the need for the correct fire weather conditions (wind, air, and plant humidity), there is usually a narrow time period in the season during which burning can be done. A mechanical or hand removal treatment might also be required prior to the reintroduction of fire into the ecosystem to achieve desired fire behavior. The disadvantages of this treatment are reduced aesthetics, tree mortality, impaired air quality, liability concerns, pretreatment costs where applicable, the requirement of qualified people who understand prescribed fire, and treatment variation (it might burn hotter or cooler than planned). Also, it might not be appropriate for some plant communities, such as low-elevation sagebrush, which can be replaced postfire by cheatgrass.

\section{Hand Cutting}

Hand cutting and stacking of fuels for burning is very labor-intensive and thus expensive. Costs range from $\$ 800$ to $\$ 2,300$ per acre, depending on amount of vegetation. It is the best alternative on steep slopes where mechanized equipment cannot operate.

\section{Grazing}

Grazing is best used when addressing the smaller diameter vegetation that makes up the 1- and 10-hour fuels. Onehour fuels are those fuels whose moisture content reaches equilibrium with the surrounding atmosphere within 1 hour and whose stems are less than one-fourth inch in stem diameter. Ten-hour fuels have stems that range from onefourth inch to 1 inch in stem diameter. Grazing can impact the amount and arrangement of these fuels by ingestion or trampling. It is a complex, dynamic tool with many plant and animal variables, and it requires sufficient knowledge of the critical control points to reach treatment objectives. Those control points involve the species of livestock grazed (cattle, sheep, goats, or a combination); the animals' previous grazing experience (which can affect their preferences for certain plants); time of year as it relates to plant physiology (animal consumption is directed by the seasonal nutrient content); animal concentration or stocking density during grazing; grazing duration; plant secondary compounds; and animal physiological state. Treatments either can be short-term to reduce flammable vegetation or longterm to change vegetation composition by depleting root carbohydrates in perennials and reducing the soil seed bank for annual plants. The objectives are to change the fire behavior through modification of the fuel bed, fuel loading, percent cover, and ladder fuels.

Depending on the plant community, the vegetation of concern or fuel will differ. The grazing approach to fuel treatment differs with the plant life cycle (annual or perennial). With annuals, the treatment is to remove plants while they are still green each year prior to fire season. Grazing before seed set can change seedbed dynamics, and with long-term implementation, grazing can change the species composition. For perennials, repeated grazing that depletes root carbohydrates and causes morality of targeted species is required to change plant composition. Root carbohydrate reserves are at their lowest level just after the period when plants initiate active shoot elongation. If plants are severely grazed early in the growing season, carbohydrate reserves are depleted, and plant vigor is reduced. ${ }^{3}$ Removal of bark or repeated defoliation are two other ways to destroy the plant. In brush species, the concept of changing the fuel profile the first year and managing it thereafter with grazing over large areas appears to be most sustainable.

Integration of different treatments could provide the best strategy. Livestock cannot effectively control mature brush plants that either grow higher than the animals can effectively graze or have large diameter limbs. Mastication, underburning, and hand-cutting can be used to manipulate the large-diameter, 100-hour brush fuels, and grazing can be used as a follow up treatment for controlling resprouting species or shifting the species composition to herbaceous plant fuel material. Tsiouvaras suggests that grazing followed by prescribed fire can be used safely to kill the aboveground parts of shrubs and further open the stand. ${ }^{4}$ Magadlela 
reported that adding cutting and herbicide use increased sheep effectiveness by reducing the brush below $20 \%$ in one year, but increased the costs. ${ }^{5}$

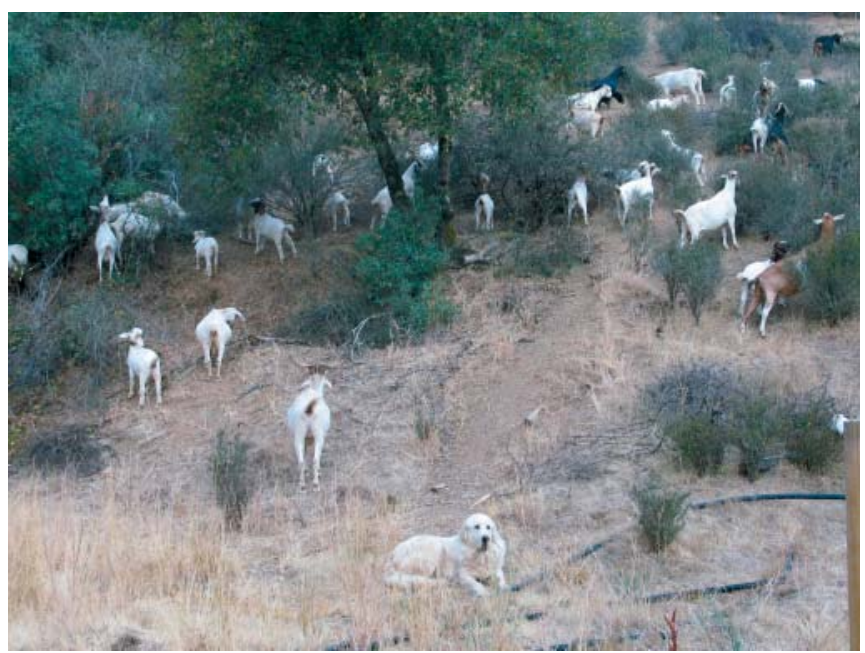

Goats grazing brush.

Prescribed grazing has the potential to be an ecologically and economically sustainable management tool for reduction of fuel loads. However, much of the information on grazing for fuel reduction is anecdotal. Limited scientific research information is available. Existing data indicate there are two ways by which grazing impacts the fuel load: removal of vegetation, and hoof incorporation of fine fuels. Smith et al. found that 350 sheep (ewes) grazing intensely on sagebrush/cheatgrass in a 2.5 -mile fuel break (divided into 20 pastures) in May in Nevada reduced fine fuels from 2,622 to 765 pounds per acre. ${ }^{6}$ Vegetative ground cover decreased $28 \%$ to $30 \%$, ground litter increased $20 \%$ to $23 \%$, and bare ground increased $4 \% .{ }^{6}$ Tsiouvaras studied grazing on a fuel break in a California Monterey pine and eucalyptus forest in the fall at a stocking rate of 113 Spanish goats per acre for 3 days; brush understory was reduced by $46 \%$ and $82 \%$ at 20 inches and 59 inches in height, respectively. Forage biomass utilization in the brush understory was $84 \%$. California blackberry showed the largest decrease in cover (73.5\%) followed by toyon, coyote brush, honeysuckle, herbaceous plants, and madrone. Poison oak and eucalyptus exhibited very little change. Goat grazing not only broke up the sequence of live fuels (horizontally and vertically up to 59 inches), but also reduced the amount of 1-hour dead fuels by $58.3 \%$, whereas the 100 -hour fuels remained constant. The litter depth was also reduced as much as $27.4 \%$ (from 2.9 inches before to 2 inches after grazing). Animal trampling resulted in crushing of fine fuels and mixing them into the mineral soil, thus reducing the chance of ignition. Green et al. grazed 400 goats on chaparral in July. ${ }^{7}$ The goats utilized $95 \%$ of the leaves and small twigs to 0.063 inches diameter from all the mountain mahogany plants. ${ }^{7}$ Use of scrub oak was $80 \%$, whereas use of chamise, eastwood manzanita, and California buckwheat was low, and Ceanothus was only taken under duress. ${ }^{7}$ Under "holding pen" conditions, use of less palatable species approached the use of palatable plants. ${ }^{7}$ Lindler reported that goats stocked at 7 per acre for 3 weeks in the summer in a ponderosa pine forest were estimated to remove $15 \%$ to $25 \%$ of the vegetation, depending on the plant species present and the length of stay in the pasture. ${ }^{8}$ The cost of the grazing treatment was $\$ 60$ to $\$ 70$ per acre. In comparison, herbicide costs on adjacent sites were $\$ 60$ to $\$ 125$ per acre, and $75 \%$ to $90 \%$ of the vegetation understory in the pine forest was removed. Intensive grazing by cattle to control shrub growth has been demonstrated as being useful for maintenance of fuel breaks. ${ }^{9-13}$ Perevolotsky et al. found that mechanical shrub removal and cattle grazing at the peak of green season in Israel 4 years in a row proved to be the most effective firebreak treatment. ${ }^{14}$ Heavy grazing for a short duration removed more than $80 \%$ of the herbaceous biomass, but reduced regeneration rate of shrubs for only 2 years. They stated that using goats or other browsing animals can increase the amount of shrub material removed by direct grazing, but can decrease actual physical damage to shrubs (cattle will trample and break more brush and graze less due to their size, whereas the opposite is true for goats). Henkin et al. found that under heavy grazing (71-83 cow grazing

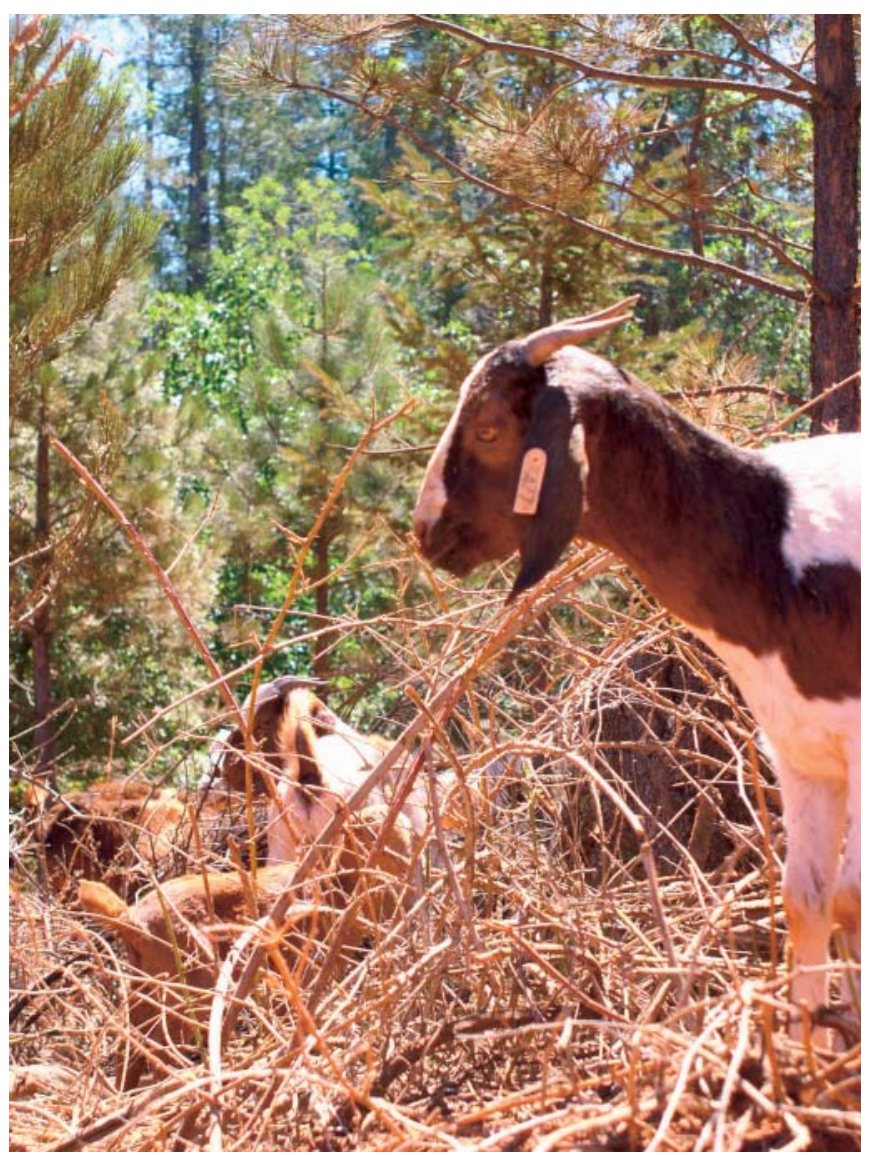

Goats grazing blackberry and other brush understory in a pine forest. 


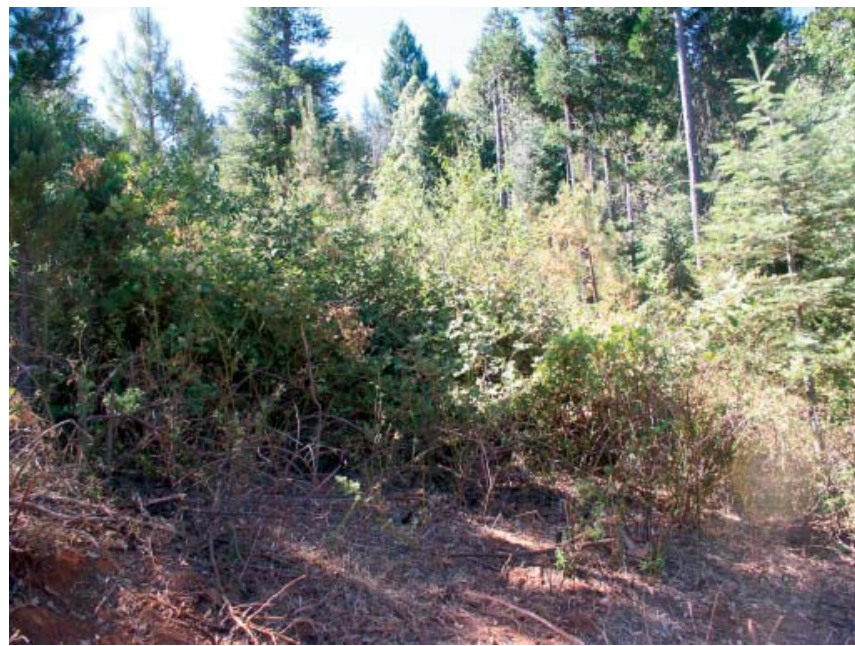

Edge of goat grazed area in Ponderosa forest.

days per acre), the basal regrowth of the oaks was closely cropped and the vegetation was maintained as predominantly open woodland. In the paddock that was grazed more moderately (49-60 cow grazing days per acre), the vegetation tended to return to dense thicket. ${ }^{12}$

Each species of animal has a unique grazing utilization pattern that is a function of mouth size and design, past grazing experience, and optimization of nutritional needs. ${ }^{15}$ The mouth size controls how closely animals are able to select and then graze a given surface. Animals also differ in their forage preferences and diet composition, thus when developing a fuel reduction grazing program, it is important to select the kind of livestock that will consume the desired species to alter the fire behavior. Provenza and Malechek showed a 50\% reduction of tannin in goat-masticated samples compared to unmasticated samples. ${ }^{16}$ This illustrates that goats can affect one of the secondary compounds that are present in some brush species, and thus can eat more of that species. When preferred forage is absent or unpalatable, grazing animals are capable of changing their food habitat.

\section{Table 1. Percent of time spent by animals feeding on diverse plant types in Texas ${ }^{17}$}

\begin{tabular}{|l|c|c|c|}
\hline \multirow{2}{*}{ Forage type } & \multicolumn{3}{|c|}{ Animal species } \\
\hline Grass & Cattle & Sheep & Goats \\
\hline Forbs & 78 & 53 & 50 \\
\hline Browse & 21 & 24 & 29 \\
\hline
\end{tabular}

Magadlela et al. found that goats grazing in Appalachian brush defoliated brush early and then grazed herbaceous material later in the seasons. ${ }^{5}$ Sheep preferred to graze herbaceous material first, but increased grazing pressure forced sheep to defoliate brush earlier in the season..$^{5}$ Goats reduced brush cover from $45 \%$ to $15 \%$ in one year. Sheep took 3 years to produce the same results. Brush clearing improved when goats followed sheep; total brush was reduced from $41 \%$ to $8 \%$ in one year. By the end of 5 years of goat grazing, the brush was reduced to $2 \%$ cover. Luginbuhl et al. found that multiflora rose was nearly eliminated from the Appalachian Mountains after 4 years of grazing by goats alone $(100 \%)$ or goats + cattle $(92 \%) .{ }^{18}$ Simultaneously, total vegetative cover increased with goats alone $(65 \%$ to $86 \%)$ and with goats + cattle $(65 \%$ to $80 \%)$, compared with the control plot where vegetation cover decreased from $70 \%$ to $22 \%$. Lombardi et al. studied the use of horses, cattle, and sheep in Northwest Italy for 5 years and found that grazing reduced woody species cover and stopped the expansion of shrub population. ${ }^{19}$ The impact varied with the type of animal. Cattle and horses had a higher impact on the plants through the damage caused by trampling. It was found that the effectiveness of control depended on palatability and tolerance of woody species to repeated disturbance. Juniper and rhododendron were reported not to have been grazed. Hadar et al. reported that the inconsistent response of some plants to grazing could be the interaction between grazing pressure and moisture conditions. ${ }^{13}$ They found that heavy cattle grazing (340-394 cow grazing days per acre) during 7 to 14 days at the end of the growing season decreased species richness because of consumption of seeds from the annual plants.

The time of the year that grazing occurs can influence the types of plants consumed, because it impacts the plant physiological status, which controls the nutritional value to the animal. Additionally, the time of year affects the plant's postgrazing mortality. Taylor reported studies using heavy grazing by sheep in Idaho showed that season of use impacted the utilization. ${ }^{17}$ Late-fall grazing reduced three-tip sagebrush, whereas grazing during spring increased sagebrush and decreased grasses.

Grazing impact can change with the density of animals and duration of grazing. The shorter the duration, the more even the plain of nutrition is. Over longer periods in a pasture, animals select the most nutritious forage first and consume less nutritious forage later. Stocking density has a great impact on the grazing consumption and trampling of fuels. Fences, herding, topography, slope, aspect, distance from water, placement of salt, and forage density all impact the distribution of animals and their use of the forage. By concentrating the animals into a smaller area for short periods of time, the preference for plants decreases and animals compete for the available forage. Increasing stocking density also increases hoof action and incorporation of the fine fuels into the ground. Spurlock et al. stated that high stocking rates with little supplementation forces goats to graze even less palatable species and plant parts, and as a result, much brush can be eradicated in 2-3 years. ${ }^{20}$ Lindler et al. suggests that a stocking rate of 15 goats per acre in a California pine forest is required to effectively treat understory brush. ${ }^{8}$ 


\begin{tabular}{l|c|c|c|}
$\begin{array}{l}\text { Table 2. Sheep diet consumption in Texas varied } \\
\text { with stocking rate }\end{array}$ \\
\hline & \multicolumn{4}{|c|}{ Forage type } \\
\hline Stocking rate & Browse & Grass & Forbs \\
\hline Light & 16 & 55 & 28 \\
\hline Heavy & 55 & 39 & 5 \\
\hline
\end{tabular}

\begin{tabular}{|c|c|c|c|}
\hline $\begin{array}{l}\text { Grazing } \\
\text { intensity }\end{array}$ & $\begin{array}{c}\text { Bare } \\
\text { soil }\end{array}$ & $\begin{array}{c}\text { Vegetation } \\
\text { cover }(\%)\end{array}$ & Litter \\
\hline Light & +6 & -22 & +25 \\
\hline Moderate & +4 & -28 & +20 \\
\hline Heavy & +4 & -30 & +23 \\
\hline
\end{tabular}

Hadar et al. reported that light grazing increased plant diversity on treated sites. ${ }^{13}$ Thus, when proposing a stocking rate for treatment consumption, the environmental impact needs to be considered.

Plants, over time, have developed mechanisms to limit or prohibit grazing. Launchbaugh et al. summarized this plant and animal interaction as follows: plants possess a wide variety of compounds and growth forms that are termed "anti-quality" factors because they reduce forage's digestible nutrients and energy or yield a toxic effect that deters grazing. ${ }^{22}$ Secondary compounds (eg, tannins, alkaloids, oxalates, terpenes) can control the plant-animal interactions that drive intake and selection. Animals might expel toxic plant material quickly after ingestion, secrete substances in the mouth or gut to render the compounds inert, or rely on the rumen microbes or the body to detoxify them. The species of livestock selected is important because some species can detoxify compounds or have a smaller mouth that allows them to eat around thorns; this allows them to still obtain nutritional or pharmaceutical products that aid in digestion and detoxification. Breeders can select for animal genetic lines that can adapt to these compounds. Tannins are the most important plant defensive compounds present in browse, shrubs, and legume forages. Concentrations in woody species vary with environment, season, plant developmental phase, plant physiological age, and plant part. Levels in excess of $50 \mathrm{~g} \cdot \mathrm{kg}^{-1} \mathrm{DM}$ can lead to low palatability, reduced digestibility, depressed voluntary feed intake, inhibition of digestive enzymes, and increased toxicity to rumen micro-organisms. ${ }^{23-27}$ In some cases, when the plant compound is known, it is possible to intercede. For example, polyethylene glycol (PEG), a polymer that binds tannins irreversibly, can be used to reduce the negative effects of tannins on food intake, digestibility, and preferences. ${ }^{28}$ For oxalates, calcium supplementation has shown to ameliorate the diet suppression. Launchbaugh et al. suggests that supplementation of protein, phosphorous, sulfur, and energy can also make a difference in intake of plant material containing secondary compounds. ${ }^{22}$ They even postulate that clay can be used to detoxify compounds. ${ }^{22}$

Grazing animals can effectively distinguish between plants that differ in digestible energy or nutrients. The animal's consumption is driven by its physiological state. Nonlactating animals have much lower nutrient requirements than lactating females or growing weaned animals and can consume a wider array of plants to meet nutritional needs. Animals can be forced to eat below their nutritional needs and they will balance their needs by using existing body fat and protein. The animal can tolerate short-term energy or protein deficits, but sustained periods at this status can be reason for concern. For this reason, lactating and young growing animals are not generally recommended for fire fuel control. In a system that is focused on maintaining the fuel profile, one can use growing animals in an annual brush grazing system that focuses on the annual new growth.

Because of the complexity of plant and animal interactions, a project evaluation should be developed that considers measurable and attainable objectives before grazing is used. It should include a review of treatment objectives, outcomes, and environmental impacts. This will dictate the kind of animal needed, grazing intensity, timing of the grazing event, and duration of the grazing period. Variation in animal-plant interaction is driven by forage type, grazing season, yearly season variation, animal interaction with the grazing system (animal density and competition), previous grazing experience, mixture of grazing animals, and pregrazing treatment (integrated approach). The treatment and resulting outcomes cannot conveniently be predicted and might require adaptive onsite management. Treatment standards include stubble height for grass, percent vegetation cover by brush, plant mortality, removal of 1- and 10-hour fuel, and fuel bed depth.

Any grazing plan designed for fuel reduction needs to consider the grazing impacts on parameters other than just simply reduction. The effects of the grazing management should be studied for their impact on water quality, compaction, riparian vegetation, disease interaction with wildlife (bluetongue, pasturella), and weed transmission. The positive aspects of grazing over other treatments also should be weighed, including recycling of nutrients into the products of food and fiber.

Grazing is best used when addressing vegetation with stems of smaller diameters that make up the 1- and 10-hour fuels. These two fuel classes are important because they can greatly impact the rate of spread of a fire, as well as flame height. Many fire managers have viewed grazing in the same context as other single-event mechanical fuel treatments. 
These grazing treatments have been expensive to implement because they have a physiological cost to the animal, and require higher costs (such as portable fencing) to reach fuel objectives in one year. Perhaps a sustainable use of grazing would be annual grazing of large areas following mechanical treatment. This provides improved nutrition by presenting smaller regrowth that is higher in nutrition; this allows animal performance to improve while maintaining a specific fuel profile in the grazing area.

There are many issues that need to be considered when examining grazing for fuel reduction. Grazing has a more varied outcome than the mechanical fuel reduction treatments. Until the grazing treatment is perfected into a fully understood tool, the dominant management strategy will be to force utilization by limiting nutrition and/or preference. There is a lack of scientific data available to help managers understand and control the many variables that influence the outcome of fuel removal, and thus reaching defined objectives will be more difficult. The objectives of the treatment must be well-defined and well-described. It is important to understand animal preference as well as proper timing in order to meet the objectives. Some have considered fuel reduction by grazing simply as a method to increase animals on public lands; thus a well-thought-out plan is important. Many do not trust agencies to administer a private sector contractor to conduct the treatment correctly; thus a contract needs to be well-defined within the parameters of the operator's control. In the past, fire managers were willing only to look at the short-term impacts and not the long-term health and fire safety of the site or the effects of a long-term grazing program. Consumptive use, such as grazing, might not be compatible with recreation land use in some areas. A survey by Smith et al. indicated that $90 \%$ of residents near a fuel break stated use of sheep was an acceptable method for fuel reduction. ${ }^{6}$ Only $10 \%$ felt that they were inconvenienced by the treatment. Some responses indicated misconceptions held by residents regarding grazing and grazing management methods; one such example was fear of possible electrocution of animals and humans by

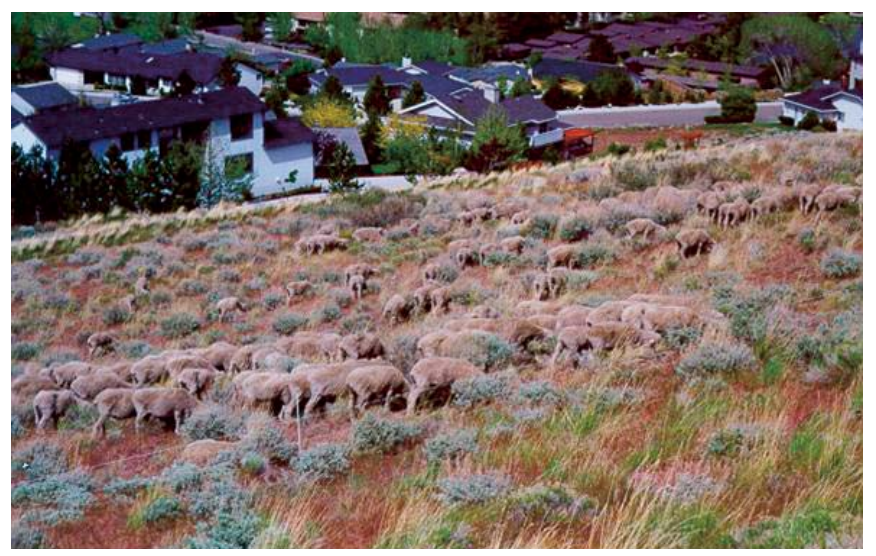

Sheep grazing a fuel break in Nevada. electric fences. These misconceptions by the public must be addressed when land managers make proposals for grazing.

\section{Conclusions}

Modification of wildfire fuels is an important issue in many regions of the world. At present, limited research knowledge exists to help guide managers in using grazing animals for fuel management. That knowledge is necessary to direct the timing and intensity of grazing to reach fuel management objectives similar to other methods. Also seasonal variation of nutrition content and secondary compounds of shrubs need to be further defined. Most of the grazing fuel modification study work has been conducted with goats, primarily because of their preference for targeted plant species. Grazing animals can modify wildfire fuels through consumption and trampling. Animals are most effective at treating smaller-sized live fuels and 1- and 10-hour fuels. These fuels influence an important part of fire behavior by providing the flammable material that creates a ladder of fuel in order for a fire to extend up from the ground into the brush and tree canopy. There is a lack of research knowledge upon which to draw in order to refine the grazing treatment to meet fuel management objectives. Many treatments in the past had only a single grazing year focus. This strategy can be effective in a grass ecosystem if timed right, but systems with abundant shrubs often require multiple years to create and maintain a fuel profile that is more desirable.

More research needs to be done to allow effective use of grazing as a fuel reduction tool. Further research also needs to be done on secondary compounds in brush plants, their seasonal variation, and methods to overcome them to achieve target utilization levels. Knowledge of the nutrient status of the plants throughout the year also will assist in indicating the time of optimum utilization of grazing in fire fuel reduction.

\section{References}

1. National Interagency Fire Center. 2006. Wildland Fire Statistics. Available at: http://www.nifc.gov/stats/index.html. Accessed January 2006.

2. Davidson, J. 1996. Livestock grazing in wildland fuel management programs. Rangelands 18:242-245.

3. Doescher, P. S., S. D. Tesch, and M. Alejandro-Castro. 1987. Livestock grazing: a silvicultural tool for plantation establishment. Journal of Forestry 85(10):29-37.

4. Tsiouvaras, C. N., N. A. Havlik, and J. W. Bartolome. 1989. Effects of goats on understory vegetation and fire hazard reduction in a coastal forest in California. Forest Science 35:1125-1131.

5. Magadlela, A. M., M. E. Dabaan, W. B. Bryan, and E. C. Prigge. 1995. Brush clearing on hill land pasture with sheep and goats. Journal of Agronomy and Crop Science 174:1-8.

6. Sмith, E., J. Davidson, H. Glimp. 2000. Controlled sheep grazing to create fuelbreaks along the urban-wildland 
interface. Proceedings of the 53rd Annual Meeting of the Society of Range Management; Boise, ID. 6 p.

7. Green, L. R., C. L. Hughes, and W. L. Graves. 1987. Goats control of brush regrowth on Southern California fuel-breaks. In First International Rangeland Congress; 14-18 August 1987; Denver, CO. p. 451-455.

8. Lindler, D., J. Warshawer, and D. Campos. 1999. Using goats to control understory vegetation. Forest Vegetation Management Conference 20:33-46.

9. Allen, B. H., And J.W. Bartolome. 1989. Cattle grazing effects on understory cover and tree growth in mixed conifer clearcuts. Northwest Science 63:214-220.

10. Gutman, M., Z. Henkin, Z. Holzer, I. Noy-Meir, and N. G. Seligman. 1991. Beef cattle grazing to create firebreaks in a Mediterranean oak maquis in Israel. In Proceedings of the IV International Rangeland Congress, Montpellier, France. p. 204-209.

11. Masson, P., and C. Guisset. 1993. Herbaceous and shrubby vegetation evolution in grazed cork oak forest firebreaks sown with subterranean clover and perennial grasses. In Proceedings of the 7th Meeting FAO European Sub-network on Mediterranean Pastures and Fodder Crops, Crete. p. 201-205.

12. Henkin, Z., M. Gutman, H. Aharon, A. Perevolotsky, E. D. Ungar, and N. G. Seligman. 2005. Suitability of Mediterranean oak woodland for beef herd husbandry. Agriculture, Ecosystems and Environment 109:255-261.

13. Hadar, L., I. Noy-Meir, and A. Perevolostsky, 1999. The effect of shrub clearing and intensive grazing on the composition of a Mediterranean plant community at the functional group and species level. Journal of Vegetation Science 10:673-682.

14. Perevolotsky, A., R. Schwartz-Tzachor, and R. YonAtan. 2002. Management of fuel breaks in the Israeli Mediterranean ecosystem. Journal of Mediterranean Ecology 3(2-3):13-22.

15. Bелsоm, S. L. 1980. Dietary overlap between cattle, domestic sheep, and pronghorns. In R. E. Soesbee and F. S. Guthery [eds.]. Noxious Brush and Weed Control Research highlights. Volume 11. Lubbock, TX: Texas Tech University. p. 40-41.

16. Provenza, F. D., And J. C. Malechek. 1984. Diet selection by domestic goats in relation to blackbush twig chemistry. Journal of Applied Ecology 21:831-841.

17. TAylor, C. A. 1994. Sheep grazing as a brush and fine fuel management tool. Sheep Research Journal 10:92-96.

18. Luginbuhl, J. M., T. E. Harvey, J. T. Green, M. H. Poore, ANd J. P. Mueller. 1999. Use of goats as a biological agents for the renovation of pastures in the Appalachian region of the United States. Agroforestry Systems 44:241-252.

19. Lombardi, G., A. Reyneri, and A. Cavallero. 1999. Grazing animals controlling woody-species encroachment in subalpine grasslands. In Proceedings of the International
Occasional Symposium of the European Grassland Federation; 27-29 May 1999; Thessaloniki, Greece. p. 85-90.

20. Spurlock, G. M., R. Plaister, W. L. Graves, T. E. Adams, And R. Bushnell. 1980. Goats for california brushland. Oakland, CA: Cooperative Agriculture Extension, University of California, Leaflet 21044. 30 p.

21. Kothmann, M. M. 1968. The botanical composition and nutrient content of the diet of sheep grazing on poor condition pasture compared to good condition pasture [dissertation]. College Station, TX: Texas A\&M University. 68 p.

22. Launchbaugh, K. L., F. D. Provenza, and J. A. Pfister. 2001. Herbivore response to anti-quality factors in forages. Journal of Range Management 54:431-440.

23. Robbins, H., A. E. Hagerman, O. Hajeljord, D. L. Baker, C. C. Schwartz, and W. W. Moutz. 1987. Role of tannins in defending plants against ruminants: reduction in protein availability. Ecology 68:98-107.

24. Happe, P. J., K. J. Jenkins, E. E. Starkey, and S. H. Sharrow. 1990. Nutritional quality and tannin astringency of browse in clear-cuts and old-growth forest. Journal of Wildlife Management 54:547-556.

25. Kumar, R., and S. Vaithyanathan. 1990. Occurrence nutritional significance and effect on animal productivity of tannins in tree leaves. Animal Feed Science Technology 30:21-38.

26. Lowry, J. B., C. S. McSweeney, and B. Palmer. 1996. Changing perceptions of the effect of plant phenolics on nutrient supply in the ruminant. Australian Journal of Agriculture Research 47:829-842.

27. Bryant, J. P., F. D. Provenza, J. Pastor, P. B. Reichardt, T. P. Clausen, and J. T. Du Toit. 1991. Interactions between woody plants and browsing mammals mediated by secondary metabolites. Annual Review of Ecology and Systematics 22:431-446.

28. Villalba, J. J., F. D. Provenza, and R. E. Banner. 2002. Influence of macronutrients and polyethylene glycol on intake of a quebracho tannin diet by sheep and goats. Journal of Animal Science 80:3154-3164.

Authors are: Livestock $\Xi^{2}$ Natural Resources Advisor, University of California Cooperative Extension, 142-A Garden Hwy, Yuba City, CA 95991, ganader@ucdavis.edu (Nader); Research Leader Range Management, Agricultural Research Organization, The Volcani Center, PO Box 6, Bet Dagan, Israel (Henkin); Natural Resource Specialist, University of Nevada Cooperative Extension, PO Box 338, Minden, NV 89423 (Smith); Livestock E Natural Resources Advisor, University of California Cooperative Extension, 11477 E Ave, Auburn, CA 95603 (Ingram); and PhD Candidate in Ecology, Ecology Graduate Group, Animal Science Department, University of California, Davis (Navaraez). 


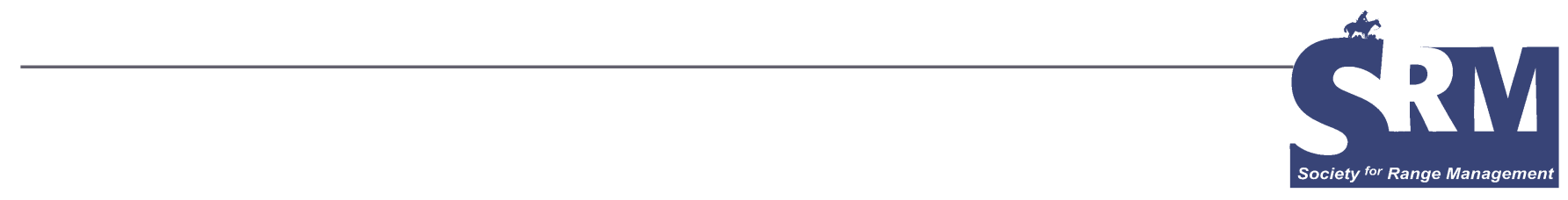

\section{Seventy Years of Pasture Rejuvenation Research}

\section{By Duane McCartney}

Editor's Note: This article is a reprint from a handout brochure of the Western Forage and Beef Group, Volume 10, Issue 3, 2006.

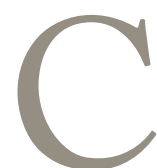

attle grazing on community pastures is part of the history of Western Canada. The idea of developing community pastures was conceived in 1922 with the establishment of the Matador pasture, $48 \mathrm{~km}$ north of the city of Swift Current, Saskatchewan. Later in the 1960s and 1970s, an international research center was established at the Matador pasture as part of a world-wide attempt to collect data on representative ecosystems and to develop computer models of them. Many of the world's present-day ecologists worked in the program as student help during data collection and analysis. The results were published in approximately 25 volumes, each the size of a big city phone book. A summary of the overall results can be found on www.foragebeef.ca.

During the "Dirty Thirties" researchers at Agriculture and Agri-Food Canada at Swift Current and Prairie Farm Rehabilitation Administration (PFRA) began to reestablish drought-stricken pastures in the southern prairies with new varieties of Russian wild rye and crested wheat grass. The involvement of PFRA in pasture and range development started in 1935 along with soil reclamation, tree planting, and water development projects. By the end of 1937,16 provincial community pastures involving 175,900 acres had been established in Saskatchewan. In addition, thirty more potential pasture areas had been surveyed for development encompassing about 400,000 acres, and 5 reserve areas were proposed to be taken out of annual cropping, reseeded to grass, and used for supplemental forage for wintering livestock. Eight pastures totaling
595,840 acres were established by the Alberta government during this time.

Many additional community pastures were developed in Saskatchewan in the 1950s and 1960s. The land came from vacant crown land, grazing leases, and from the purchase of private land. The land was marginal for cultivation and farmers on nonviable farm units were assisted to relocate or they left farming. During this time pasture development moved into the aspen parkland and forest fringe areas. Many of these areas required the clearing of tree growth and the seeding to tame forage species. The last community pasture in Saskatchewan was established in 1971, and currently the main objective for community pastures is to sustain forage production at an optimum level.

In order to clear, break, cultivate, and reseed these bushland pastures, very unique equipment was developed. Researchers at Agriculture and Agri-Food Canada Beaverlodge, Melfort, Swift Current, as well as the Provincial Lands Branch agrologists were involved. Pastures were often seeded to a "shotgun" mixture of 17 different grasses and legumes, including creeping red fescue, blue grass, and smooth brome grass with the hope that something could be established over the entire ecosystem of the newly developed pasture.

A large multidisciplinary research project was established by the Melfort Research Station in 1975 to develop methods to rejuvenate overgrazed and depleted roughland bush pastures in the aspen parkland. The Pathlow Project, as it was known, was a joint effort of Agriculture and AgriFood Canada, Saskatchewan Agriculture Lands Branch, and the Saskatchewan Horned Cattle Trust Fund. The purpose was to look at different grazing management 

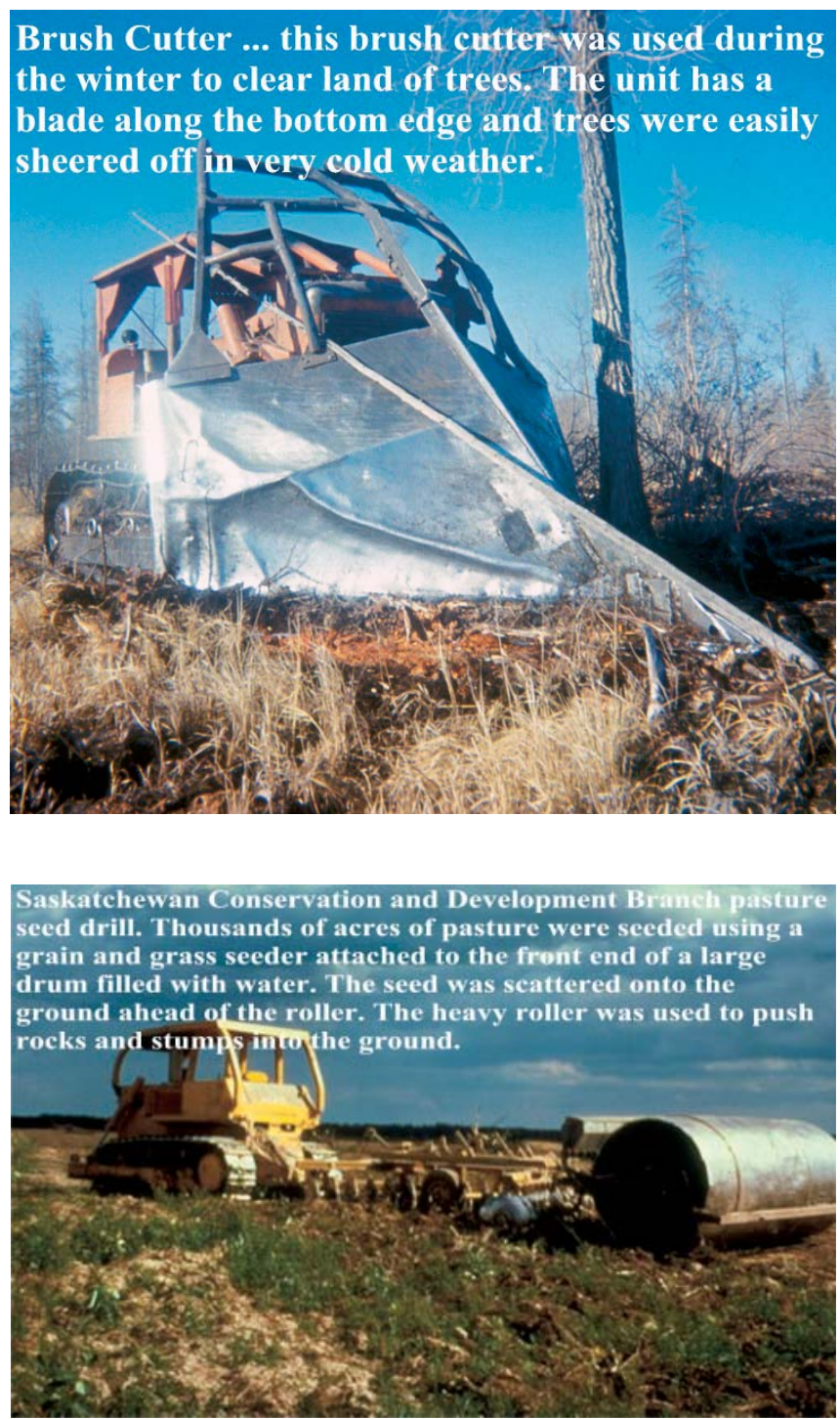

systems, soil fertility, forage species adaptation, diversity, and extension of the grazing season.

Initially, Russian wild rye grass and crested wheat grass were seeded for early grazing. The Russian wild rye grass was difficult to establish and basically only grew on the drier hills. It could not compete with volunteer blue grass and smooth brome grass on the drier areas. Crested wheat grass established very well. It was heavily grazed for 2 to 3 weeks early in the grazing season so that it did not go to seed. These grazing areas were allowed to rest for the remainder of the growing season and were later grazed in the fall. This provided about 2 weeks of extra grazing in the spring and another 2 weeks in the fall, compared to the remainder of the perennial pastures.

A unique grazing trial was later established to assess how individual grass and legume species could survive under different levels of grazing pressure. The "Mob grazing trial" consisted of a large number of cattle grazing the plot area: 1) 5 times a year to simulate continuous grazing; 2) a light grazing twice a year in mid-June and mid-September; and 3) a third moderate treatment of the grazing 3 times a year. The cattle were left on the treatment areas for 1 to 2 days until all vegetation had been grazed down. Thirteen cool-season grass species and 9 alfalfa species were evaluated for several years for persistence. Parkway crested wheat grass, Carlton smooth brome grass, and meadow brome grass were the most persistent. Intermediate wheat grass and northern wheat grass disappeared the quickest and were replaced by bluegrass. The falcate type of alfalfa with yellow flowers had the greatest persistence of all the alfalfas tested. As a result of this initial trial a new variety of alfalfa called "Yellowhead" will officially be released for use in the coming year. However, this will depend on seed supply.

Yellowhead alfalfa 20 years after seeding. This plot of Yellowhead alfalfa was seeded in 1986 at the Pathlow Pasture Research site in Saskatchewan. It has been subjected to different periods of grazing and rest over the years.

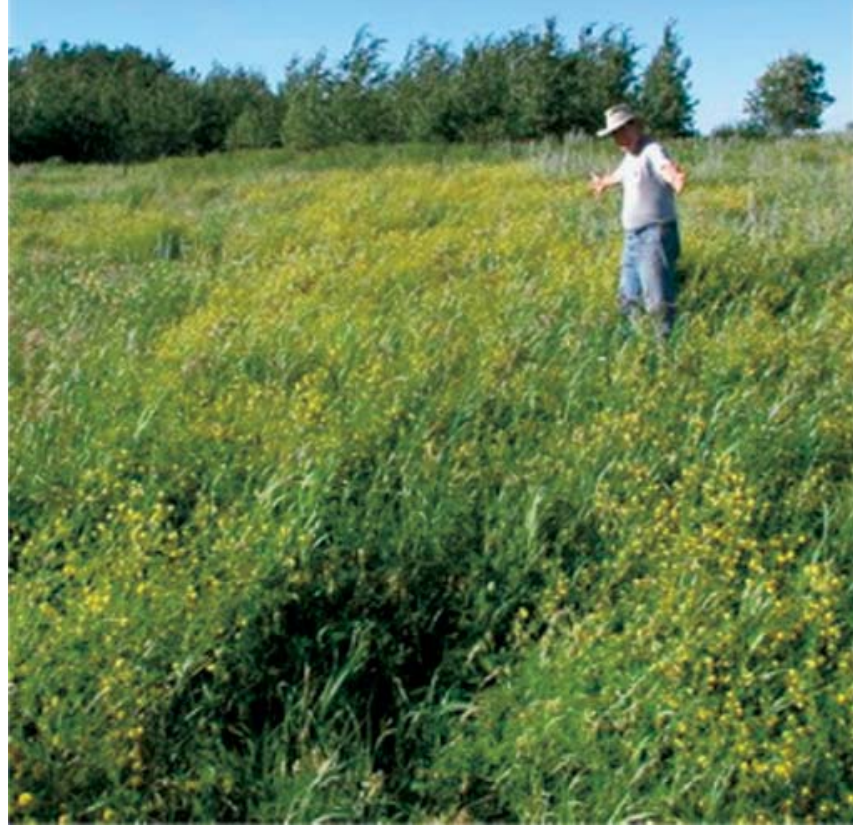

Over the years, additional fertility, species selection, seeding methods, and pasture monitoring systems were developed through the Pathlow Research Project. Summaries of these projects can be found on www.foragebeef.ca.

Several areas of the research site were seeded to tame forages. However, over time these sites were taken over by invading blue grass and smooth brome grass. Because these pastures had been seeded to the original "shotgun mixture," including blue grass and smooth brome grass in the mid 1960s, the soil contained a large seed bank of dormant blue grass and smooth brome grass seed. If the objective of pasture reseeding on your farm is to establish a different 
species on the landscape, then it would be advisable to seed an annual cereal on this land for a few years in order to reduce the impact of the dormant seed bank. Kentucky blue grass (Poa pratensis) is a major component of pastures in the aspen parkland. It was likely the first cultivated grass to arrive in the new world from Europe and might have arrived in Canada in the early 1800s as referred to in "The dark side of Kentucky blue grass," Cattlemen Magazine (Oct. 2005).

Thirty years after the start of the Pathlow Pasture Project one can still learn from the ever-changing ecological system. Some of the overgrazed and depleted areas were allowed to rest for different periods of time.

I revisited the site this summer and found heavy stands of smooth brome grass where only minimal stands of blue grass and antennaria or everlasting (weed) previously grew. The vegetation on these fields was so sparse in the 1970s and 1980s that it only provided $2.2 \mathrm{AUM} \cdot \mathrm{ha}^{-1}$ of grazing. The crested wheat grass stands, when previously fertilized with $80 \mathrm{~kg}$ of $\mathrm{N}$ and $45 \mathrm{~kg}$ of $\mathrm{P}_{2} \mathrm{O}_{5}$, provided early and late fall grazing for about 10 years. These stands have now reverted back to the original smooth brome grass and blue grass swards. Over the years, the meadow brome grass has been dominated by smooth brome grass. Interestingly enough, in the former mob grazed area, the Yellowhead and Anik alfalfa have persisted for 20 years. During the past few years this area was not grazed.

Pasture stands have successfully been revitalized by allowing the forage species to rest until September for several years, followed by a heavy graze in the late fall. In these areas, a highly productive pasture stand was rejuvenated over the years at a very low cost.

From this long term pasture rejuvenation project, we have shown that depleted pastures in the aspen parkland can be rejuvenated through rest periods with no additional inputs.

For a complete summary of pasture rejuvenation research in Western Canada go to www.foragebeef.ca.

Author is Forage Beef Systems Research Scientist, Western Forage Beef Group, Agriculture and Agri-Food Canada, Lacombe, Alberta, Canada, email: mccartneyd@agr.gc.ca. 


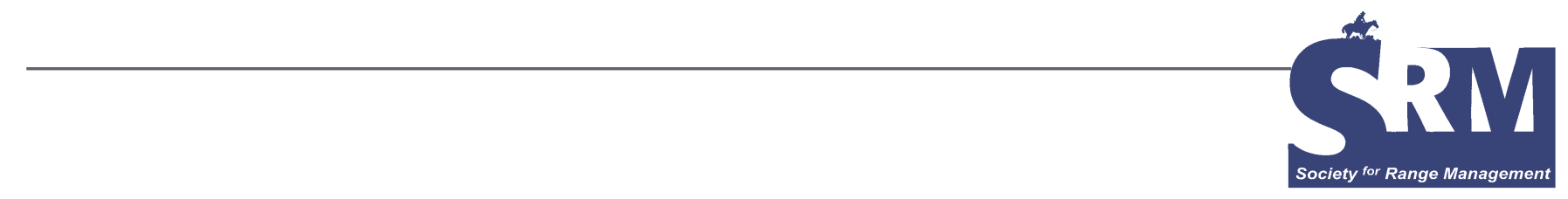

\section{Western Ranching, Trade Policies, and Peak Oil}

\section{Skyrocketing trade deficits coupled with depletion of oil and natural gas reserves could make rangeland livestock production essential to food security in the United States.}

\section{By Jerry L. Holechek and Jerry Hawkes}

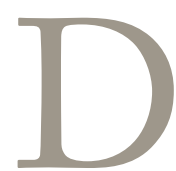

uring the past 12 years ranchers in the western United States have confronted great change and hard times. In New Mexico, where we live, annual surveys by range economists at New Mexico State University show that, as a group, ranchers have been steadily losing money since 1994 (Table 1). Even though there has been a gradual upward trend in cattle prices since 1996, extended drought and rising costs have kept most ranches financially in the red. Other segments of agriculture in the United States have also confronted a profit squeeze due to inadequate prices and rising costs. This is in contrast to the American and world economy, which have experienced an extended boom since 1991, interrupted by only a brief and mild slowdown in 2001 and 2002. It would seem that improved world economic conditions, coupled with rising world human populations (about $\left.1.2 \% \cdot y^{-1}\right)$ and nationally $\left(1 \% \cdot y^{-1}\right)$ would benefit America's farmers and ranchers. However, this has not been the case. Lack of profitability has undoubtedly been a critical factor in the unprecedented conversion of western ranches into other uses. ${ }^{1}$

We have read several articles and books by economic and natural resource experts that have caused us to conclude that world trade policies and rising energy costs have been important factors explaining the plight of ranchers since the early 1990s. Much has changed since we last addressed macro-economic factors affecting ranchers. ${ }^{2}$ Therefore, in this article we will again examine how global conditions relating to trade and energy are affecting western ranchers. In addition we will provide insight into future challenges and opportunities confronting western ranchers.

\section{A Modern World Trade Policies History}

In order to develop this discussion we have drawn heavily on 4 recent books by respected economists that comprehensively explain current world trade policies. ${ }^{3-6}$ These economists make it clear that basic knowledge of monetary policy by the United States government is essential in understanding globalization and modern world trade. We will summarize these discussions on this subject.

During most of its history, the United States government closely tied the supply dollars to reserves of gold. ${ }^{4}$ Immediately following World War II in 1946, the major trading countries of the world reached an accord (the Bretton Woods Agreement) that United States dollars would serve as the basic monetary unit of exchange for international trade. Any country holding dollars could readily acquire or exchange them for gold with the US government at the rate of 32 dollars per ounce of gold. The Bretton Woods Agreement basically gave the United States control of the free world's money supply. From the late 1940s into the early 1960s, the United States accumulated large gold reserves as it was the world's largest manufacturing economy and exporter of products. By the second half of the 1960s, the rebuilding of the Japanese and European economies, the proliferation 


\begin{tabular}{|l|c|}
\hline $\begin{array}{l}\text { Table 1. Net returns } \\
\text { ranches, 1986-2004* }\end{array}$ & New for New Mexico \\
\hline Year & 50.30 \\
\hline 1986 & 104.30 \\
\hline 1987 & 95.55 \\
\hline 1989 & 78.97 \\
\hline 1991 & 77.40 \\
\hline 1992 & 76.61 \\
\hline 1993 & 61.93 \\
\hline 1994 & 9.32 \\
\hline 1995 & -41.62 \\
\hline 1996 & -14.00 \\
\hline 1997 & 22.55 \\
\hline 1998 & 31.94 \\
\hline 1999 & 25.85 \\
\hline 2000 & -3.99 \\
\hline 2001 & -6.21 \\
\hline 2002 & Net \\
\hline 2003 & \\
\hline 2004 & \\
\hline
\end{tabular}

*Source: Data from New Mexico State University Agricultural Experiment Station reports prepared by Dr. Jerry Hawkes, range economist, New Mexico State University.

of social programs in the United States, and the high costs of the Vietnam war caused rapid buildup in the number of dollars in foreign lands. Foreign governments began exchanging their dollars for gold at the US Federal Reserve. Initially there was little concern, but by 1970, the flow of gold from Fort Knox had become a torrent. In August of 1971, President Nixon suspended the convertibility of dollars into gold. After failed attempts to revise the Bretton Woods system, the major trading powers agreed to allow their currencies to float freely against one another. However, the dollar remained as the world's primary monetary unit. Because currencies were no longer tied to the finite supply of gold, but rather to US dollars, various governments, including the United States, could and did increase their currencies at will. This allowed US government budget deficits to drastically increase and trade deficits with other nations to become chronic and reach enormous levels.

Without the monetary discipline (gold-backed dollars) of the Bretton Woods Agreement, the United States has gone from the world's largest creditor to the world's largest debtor. ${ }^{3,4,6}$ Total foreign debt owed by the United States has skyrocketed from 350 billion dollars in 1980 to nearly 6 trillion dollars in 2007. Annual trade deficits are rapidly increasing and will be over 800 billion dollars in 2006 (Table 2).

The United States, which is the world's largest economy, has become the world's engine of economic growth because it now imports over $80 \%$ more products on a dollar-valued basis than it exports to the rest of the world (Table 2). Basically, the health of the world economy depends on the United States constantly increasing its level of indebtedness. However, recently retired Federal Reserve Chairman, Alan Greenspan, has publicly stated he believes the large trade deficits of the United States are unsustainable. Several other economists have reached this same conclusion. ${ }^{3,4,6}$

Essentially the change from a gold to a dollar standard in 1973 lead to the age of globalization by allowing the United States to buy massive amounts of products from the rest of the world through provision of nothing more than paper dollars. This has benefited US consumers by providing them with cheap goods, services, and food from developing countries that have comparatively low-cost labor and minimal environmental regulation. Interest rates have been kept low because the abundance of cheap goods has put downward pressure on consumer prices, and hence interest rates. Another important factor causing low interest rates during the past 15 years is that foreign countries with large trade surpluses with the United States have heavily invested their dollars back into US assets, particularly treasury bonds. Foreigners now hold $40 \%$ of US government debt. ${ }^{3,46}$ Basically, expanding trade deficits have meant that foreigners hold more and more claims on US assets and production. Ultimately this could lead to a declining standard of living and impoverishment of US citizens. . $^{3,4,6}$

In order to have balanced trade, the value of the dollar will have to fall by $30 \%$ to $80 \%$ against various other foreign currencies, and various tariffs and other trade restrictions will be needed to slow the inflow of foreign goods, services, and agricultural products. This change of policy is unattractive to American politicians and most of the public because on a short term basis it would cause a rapid rise in interest rates and prices of most goods, foods, and services. ${ }^{3-6}$

Generally the primary trading partners with the United States (China, Japan, Canada, Mexico, Brazil) have favored a strong dollar relative to their own currencies. This allows them to have large trade surpluses essential for rapid economic growth in their countries. Whenever the dollar 
Table 2. United States exports, imports, and merchandise trade balances in billions of dollars (19912005)*

\begin{tabular}{|c|c|c|c|}
\hline \multirow[b]{2}{*}{ Year } & \multicolumn{3}{|c|}{ Billions of Dollars } \\
\hline & Exports & Imports & Trade Balance \\
\hline 1991 & 414 & 491 & -77 \\
\hline 1992 & 440 & 536 & -96 \\
\hline 1993 & 457 & 589 & -132 \\
\hline 1994 & 503 & 669 & -166 \\
\hline 1995 & 575 & 749 & -174 \\
\hline 1996 & 612 & 803 & -191 \\
\hline 1997 & 678 & 876 & -198 \\
\hline 1998 & 670 & 917 & -247 \\
\hline 1999 & 684 & 1,030 & -346 \\
\hline 2000 & 772 & 1,224 & -452 \\
\hline 2001 & 719 & 1,146 & -427 \\
\hline 2002 & 682 & 1,165 & -483 \\
\hline 2003 & 713 & 1,260 & -547 \\
\hline 2004 & 808 & 1,473 & -665 \\
\hline 2005 & 895 & 1,667 & -783 \\
\hline
\end{tabular}

*Source: US Department of Commerce, Bureau of Economic Analysis, US International Transaction Data.

has started to fall against particular foreign currencies, the central banks in these individual countries have purchased dollars to depreciate their own currencies and then invested the dollars into US assets and treasury bonds. ${ }^{4,5}$

During the course of the past 10 years, large portions of US manufacturing have moved to China, the US service sector has been moving to India, and the agricultural sector has been moving to Brazil and other Latin American countries. $^{5}$ In China, manufacturing jobs pay $\$ 5$ to $\$ 10$ per day compared to $\$ 160$ to $\$ 200$ per day in the United States. 5 Similar differences in wages apply to service sector jobs in India and agricultural sector jobs in Brazil. ${ }^{5}$ Under conditions of free but unbalanced trade, it is quite difficult for small and medium-sized American businesses to compete with those locating in developing countries. Generally the United States now has a trade advantage only for complex technologies involving the most current innovations. Large international companies formerly based in the United States are prospering because they have moved to other countries to take advantage of cheap labor and taxes and less environmental regulation. ${ }^{4-7}$

The other important part of the US trade deficits is that while Americans over-spend, their primary trading partners, particularly the Chinese, Japanese, and other Asian countries, over-save. ${ }^{5,6}$ American household debt is now at an all-time high of $120 \%$ of household income, and the annual savings rate is $-1 \%$ of income. ${ }^{3,6}$ In contrast, the Asians save $30 \%-40 \%$ of their income. Extreme 
over-consumption by the United States coupled with extreme under-consumption by its Asian trading partners are major factors in the enormous trade deficit of the United States.

\section{Financial Situation of Western Ranchers}

The financial outlook for western ranchers has changed somewhat since our analysis 12 years ago. ${ }^{2}$ At that time, low energy costs, declining per capita consumption of beef, several years of favorable precipitation, and increasing competition from Argentina and Australia were factors causing real cattle prices to be at historically low levels. Nevertheless, as a group, ranchers in New Mexico and other western states made a profit in nearly all years during the 1980s and early 1990s. Since 1994, extended drought has been an important factor depressing ranch profitability in New Mexico and several other states. Since 1996, cattle prices have been in an uptrend due to an increasing human population with rising affluence, increased per capita consumption of beef, depressed cattle numbers due to drought, and depressed beef production in Europe due to mad cow disease (bovine spongiform encephalopathy). In the period from 1992 to 2006, domestic beef consumption in the United States grew by $14 \%$ while beef exports from the United States increased by $85 \% .{ }^{8}$ However, after the December 2003 discovery of mad cow disease in a Washington state dairy cow, various countries banned some or all US beef and cattle products. In 2003, the United States had 18\% of the world beef market and was the third largest beef exporter behind Australia and Brazil. In 2004, the United States' share of the world's beef market plummeted to 3\%, whereas Brazil held $27 \%$ and Australia held 20\%.

Japan (37\%), followed by Korea (24\%), Mexico (20\%), and Canada (10\%) have been the largest importers of US beef. Japan substituted beef from other sources (primarily Australia and New Zealand) for beef it was importing from the United States prior to $2004 .{ }^{8}$ However, in mid-December 2005, Japan lifted its ban on beef imports from the United States. Through 2004 and 2005, US beef prices held up well despite the US beef ban in Japan and other countries. This is explained by lower US cow inventories due to drought in the Great Plains, steady US beef demand, and a 2003 ban on importation of beef and cattle from Canada into the United States

In 2007, it is expected that US beef exports will increase to $6 \%$ or more of the world market, compared to $3 \%$ in 2004. The United States is slowly regaining market share it lost from the "mad cow disease" scare in 2003 because Canada, Mexico, and Japan are again accepting US beef. Restrictions on cattle and beef imports from Canada in 2003 due to "mad cow disease" indicate that US cattle prices are more positively impacted by decreases in imports than reductions in exports. The United States is the largest importer of beef in the world. In recent years, imports have accounted for about $13 \%$ of total beef consumption in the
United States. ${ }^{8}$ Until the ban on Canadian beef in May, 2003, Canada was the primary source of beef imports into the United States. Historically, Canada has exported around $60 \%$ of its beef production with $80 \%-90 \%$ going to the US.

Range livestock production in the western United States does not operate apart from the world economy and globalization. There is increasing controversy over the free trade policies of the US government since the late 1980s. This is because of the escalating US trade deficit previously discussed and relocation of the US manufacturing base to China, service sector to India, and agricultural sector to Brazil. Various trading partners of the United States engage in policies of currency manipulation, subsidization, and less stringent environmental regulation that put US producers at a disadvantage. ${ }^{5,7}$ This applies to western cattle ranchers as well as many other types of businesses.

\section{Range Livestock Production and Peak Oil}

A new factor that could greatly affect United States agriculture, including range cattle operations, is "peak oil." There is credible but controversial evidence that world oil production might be nearing or at a peak and will start to decline within 3 to 15 years. ${ }^{9,10}$ At the same time, world demand for oil is rising about $1.6 \%$ per year. Once world oil production begins to decline, global agriculture could drastically change. ${ }^{9,11}$ This is because the big boosts in food production over the past 40 years from the "green revolution" depend heavily on fertilizer, herbicides, pesticides, and irrigation linked to fossil fuel (oil and natural gas) use. The cheap feed grains used in productions of chickens, pigs, and cattle could become a thing of the past. Under the future scenario predicted by Kunstler of severe world fossil fuel shortages, the United States could be forced to produce most of its own food using low-intensity agricultural practices of the nineteenth century. Range livestock production would again play a critical role in providing the nation with meat. Although the predictions of Kunstler seem both dire and extreme, some, but not all energy experts believe that world oil/natural gas shortages with 3 to 25 years are a possibility., ${ }^{9,12}$ The pessimists further point out that all of the alternative energy sources including biomass, coal, wind, nuclear power, and fuel cells presently have limitations as replacements for oil and natural gas. Our own analyses indicate that great uncertainty exists regarding world supplies of fossil fuels and the potential of alternative energy sources to replace them. Sustaining food production on US farmlands and rangelands is a rational hedge against the dark scenario prophesized by Kunstler.

Keep in mind, range livestock production involves 30\% to $80 \%$ lower energy inputs than present production systems depending on degree of fattening and amount of meat transport. High shipping costs in conjunction with dollar devaluation could make importation of meat from other countries infeasible. Meat and agricultural produce produced 
locally and regionally could become much cheaper than imported food.

Here we will comment about the quality of grassfattened beef. In the United States, grass-fattened beef is considered inferior to grain-finished beef in terms of tenderness and taste. This is largely due to lack of proper aging of grass-fattened beef. It takes $2-4$ weeks of aging to properly prepare grass-fattened beef for the table. We have eaten much properly aged grass-fattened beef that we considered superior in taste, tenderness, and healthiness to the corn-fed beef sold in the large US chain food stores and restaurants. Improved profit margins for ranchers and the decline of the large retail chain stores (Wal-Mart) due to the end of abundant cheap oil could make it profitable for ranchers to raise, properly age, and sell their beef in local markets. Some ranchers in New Mexico are already doing this.

\section{Finall Thoughts}

Generally, the public, the news media, and politicians project a continuation of the trend towards globalization now in progress. Improved communication, adoption of market economies, cheap energy, free trade, and massive trade deficits by the United States have all been factors favoring rapid globalization since 1990. Globalization has greatly altered the US economy from being primarily exportoriented to import-oriented. It has provided the US consumer with cheap manufactured goods and food shipped long distances at the expense of local industries and agriculture. Escalating trade deficits, consumer debt, and public debt in the United States have caused some economists to strongly question whether globalization as it is now practiced can continue. Key features of globalization are the need for cheap energy and never ending debt expansion by the United States. Because the United States is the world's largest economy and controls the world's money supply through the dollar, it has had the capability to consume more than it produced for the past 33 years. If world leaders should decide to end the dollar's role as the world's primary monetary unit, the United States could lose much of its cheap import capability and would again have to rely heavily on domestic production. A new emerging factor that could alter globalization is the possibility "peak oil." This controversial concern centers around a limit to the amount of oil that can be extracted due to declining world supply, coupled with increasing world demand. Rapid economic growth in China, India, Brazil, Russia, and other countries as well as increased demand in the United States is straining world oil supplies. Some energy experts express doubt that cheap, alternative energy sources can be easily developed and substituted for oil. ${ }^{9-12}$ If this proves true, then the trend toward globalization might be reversed. The United States might again be forced to rely on domestically produced goods and food. However, the production of these goods and food could be far more costly than in the age of cheap oil. Lower-input agricultural systems similar to those at the end of the nineteenth century might be the only alternative if there are no breakthroughs that provide cheap energy after peak oil. Under this scenario, rangeland livestock production would play a critical role in providing the nation with meat. Therefore, we consider it highly important to national security to conserve the nation's rangelands and sustain livestock production (ranching) on both public and private rangelands.

\section{References}

1. Holecheк, J. L. 2006. Changing western landscape, debt, and oil: a perspective. Rangelands 28:1-6.

2. Holechek, J. L., J. Hawkes, and T. D. Darden. 1994. Macroeconomics and cattle ranching. Rangelands 16:118-123.

3. Swanson, G. J. 2004. America the broke. New York, NY: Doubleday Books. 206 p.

4. Duncan, R. 2005. The dollar crisis: Causes, consequences, cures. Hoboken, NJ: John Wiley \& Sons. 324 p.

5. Prestowitz, C. 2005. Three billion new capitalists. New York, NY: Basic Books. 321 p.

6. Bonner, B., And A. Wiggin. 2006. Empire of debt: The rise of an epic financial crisis. Hoboken, NJ: John Wiley \& Sons. $370 \mathrm{p}$.

7. Kynge, J. 2006. China shakes the world. New York, NY: Houghton Mifflin Company. 270 p.

8. Hanrahan, C. B., and G. S. Becker. 2006. Mad cow disease and U.S. beef trade. Congressional Research Service. Washington, DC: The Library of Congress. 5 p.

9. Heinberg, R. 2005. The party's over. 2nd ed. Gabriola Island, Canada: New Society Publishers. 306 p.

10. Simmons, M. 2005. Twilight in the desert: The coming Saudi oil shock and the world economy. Hoboken, NJ: John Wiley \& Sons. 422 p.

11. Kunstler, J. K. 2005. The long emergency. New York, NY: Grave Press. 324 p.

12. Tertzakian, P. 2006. A thousand barrels a second. New York, NY: McGraw-Hill. 272 p.

Authors are Professor of Range Science, Department of Animal and Range Sciences, holechek@nmsu.edu (Holechek); and Assistant Professor, Department of Agricultural Economics and Business, New Mexico State University, Las Cruces, NM 88003 (Hawkes). This paper was supported by the New Mexico Agricultural Experiment Station and was part of project 1-5-27410. 


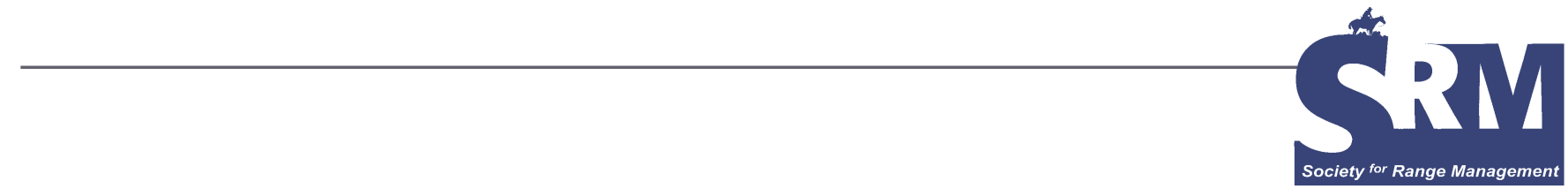

\section{National Security and} Rangelands

\section{Depletion of fossil fuels and global warming could drastically reduce world food production. Conserving and improving rangelands is important, because they likely will play an increased role in meeting world food needs.}

\section{By Jerry L. Holechek}

I $\mathrm{n}$ recent years, the term "national security" has been increasingly used by US politicians to justify major military and economic spending programs by the federal government. These national security spending programs initially centered on protecting US citizens from terrorist attacks following the September 11, 2001 destruction of the New York World Trade Center buildings. However, the term "national security" is becoming more inclusive, taking into account energy, climate, transportation, the economy, and food production and distribution. Both energy (peak oil) and climate (global warming) concerns are receiving more attention by the politicians and news media but they remain greatly overshadowed by the "War on Terror."

Critics of the "War on Terror" tend to focus on the high natural resource consumption (particularly oil and natural gas) levels of the United States compared to other countries. ${ }^{1-3}$ Many see the major problem as the heavy US dependence on oil imports from certain foreign countries that are not dependable friends or politically stable.

Although various books and articles have been written that make the case for less reliance on imported resources, there has been little focus, discussion, or debate on this matter by the politicians and news media. In reality, the accelerated trend towards globalization since 1990 has greatly increased US dependence on imported resources and goods. ${ }^{4,5}$ It is amazing to me that the relevance of rangelands in meeting the national security needs of the United States is seldom mentioned by the politicians or news media, even though rangelands comprise half the total land area of the United States.

The American Farmland Trust ${ }^{6}$ summarizes justification to conserve and protect agricultural lands, including rangelands. In general, they make the case that saving agricultural lands from development is advantageous, both economically and environmentally, but they do not imply or directly state this is essential for national security. Primary economic reasons given to save agricultural lands include importance of agricultural products in international trade and employment of nearly 23 million people in the nation's food production system. Environmental reasons for saving agricultural lands include their importance for wildlife habitat, clean air, water, flood control, ground water recharge, and carbon sequestration. Other socially related justifications are preservation of cultural heritage, scenic views, open space, and community uniqueness. Although these reasons are all compelling, they thus far have not led to any federal initiatives to slow the rate of development of agricultural lands. From 1992-2003, the rate of development of agricultural lands has actually increased by $50 \%$ compared to the previous decade. ${ }^{6}$ Since 1994 , lots of 10 to 22 acres have accounted for $55 \%$ of the growth in housing areas.

Although the trend in agricultural land loss might seem alarming, there is a counterview that the United States still has a vast abundance of agricultural land, and conversion 
is small relative to the total base. ${ }^{7}$ About $5.5 \%$ of the land in the United States is considered to be developed. Development of agricultural lands often results in accelerated economic growth in local communities with more and higher paying jobs than with agriculture alone. Restrictions on development of agricultural lands at the federal, state, and/or county level interfere with free market forces and compromise private property rights. In states such as Oregon and California, with intensive land use restrictions, home availability and prices are bid up due to the lack of land for subdivisions.

After reading a number of articles and books on problems relating to urban sprawl, food production, fossil fuel depletion, and global warming, I have become convinced there are more compelling reasons to conserve agricultural lands from development beyond those I have previously summarized. These reasons are related to transportation, food, and climate security. Of these, I believe food security could be the most important. From here I will make the case that both conserving and improving rangelands will be critical in security needs, emphasizing food production.

\section{American Agriculture-A Success Story?}

The United States' abundance of cheap food is considered to be one of the country's greatest achievements. ${ }^{8,9}$ While people in most parts of the world spend about $40 \%$ of their disposable income on food, in the United States we spend only $10 \%$. Americans eat better and at the same time spend a lower percentage of their income on food than any other country. Today, less than $1 \%$ of the work force in the United States engages in farming and ranching. Some examples of changes in agricultural production from the 1950s to the present include the following: annual egg production has jumped from 183 to 243 eggs per laying chicken, milk output has increased from 5,400 to 12,100 pounds per cow, wheat output has increased from 17 to 35 bushels per acre, and corn output has jumped from 39 to 102 bushels per acre. ${ }^{8}$ During this same period, farm output per hour of labor has increased a phenomenal 700\%. Since World War II, agricultural exports from the United States have played a critical role in meeting the food needs of several developing countries. Agricultural products have been primary exports from the United States during several periods since World War II. In spite of its successes, the capability of US agriculture to meet future food needs, both at home and abroad, is being questioned. ${ }^{10-13} \mathrm{~A}$ number of problems confront American agriculture, including soil erosion, restricted water supplies, water pollution, atmospheric pollution, global warming, urban sprawl, rapidly rising fossil fuel costs, and plant biological yield limits. ${ }^{10,11,13}$ Although the United States has long been the world's leading exporter of agricultural products, it has also recently become the leading importer. In 2006, the United States became a net importer of agricultural products for the first time, after nearly 50 years of being a net exporter of agricultural products.
Since 1960, the "green revolution" has been the primary factor explaining the tremendous increase in world food production. ${ }^{10,13,14}$ Its key features are genetic selection of highly adapted plant species that are responsive to large inputs of inorganic fertilizer, pesticides, and irrigation water. ${ }^{10,14}$ Three- to five-fold increases in yields over traditional varieties were possible with appropriate water, fertilizer, and pesticide inputs. Faster growth of certain green revolution plants has permitted multiple cropping on the same amount of land.

The primary problems now emerging with the green revolution are depletion of the world's supply of fossil fuels and ground water for irrigation. ${ }^{10-12}$

\section{Human Population, Food, and Energy}

Since 1950, to the present, the world human population has increased $250 \%$, from 2.6 to 6.5 billion people. This increase has been made possible by a $300 \%$ grain yield increase from the green revolution. ${ }^{10}$ The world human population is projected to grow from 6.6 to 9 billion people by 2042 according to the US Census Bureau. However, some experts are now questioning whether the world can support the present human population, let alone another 2 to 3 billion people. ${ }^{2,11,15}$ Their primary concern centers around the heavy dependency of modern agriculture on fossil fuels. A secondary concern is the impact of climate change on food production. Between 1945 and 1994, energy inputs to agriculture have shown a 4-fold increase, but crop yields have shown only a 3 -fold increase. ${ }^{16}$ Since 1994, energy input has continued to increase without a corresponding increase to crop yield. ${ }^{10}$ American agriculture's energy use is partitioned as follows: $31 \%$ for fertilizer manufacture, $19 \%$ for operating field machinery, $16 \%$ for transportation, $13 \%$ for irrigation, $5 \%$ for pesticide production, and $16 \%$ other. ${ }^{10}$ Energy costs for packaging, refrigeration, transportation to retail outlets, and household cooking are not included in these figures. An increasing percentage of the food consumed by Americans comes from other countries. ${ }^{10}$ Based on USDA data, an estimated $39 \%$ of fruits, $12 \%$ of vegetables, and $78 \%$ of fish are imported. Currently, the average food item consumed in the United States travels about 1,500 miles, compared to 1,250 miles 20 years ago. ${ }^{17}$ For every calorie used in actual food production, up to 5 more are used for processing, storage, and transport. Every aspect of food production, processing, distribution, and consumption depends on oil and natural gas supplies. Without question, food security in America relies heavily on the steady availability of cheap oil and natural gas. Because the United States is so heavily dependent on oil and natural gas imports, there is growing concern this could be our Achilles heel. ${ }^{18-20}$

\section{Growing Concern Over Peak Oil}

"Peak oil" is a term commonly used in reference to global oil production reaching a maximum and then declining due 
to depletion of finite reserves under stable or increasing demand. ${ }^{10,18,20}$ Considerable controversy has surrounded exactly when this might occur, although it is well-accepted that it will occur because oil is a finite, nonrenewable natural resource. ${ }^{18,20}$ In February 2007, the US General Accounting Office (GAO) concluded that peak oil will likely occur between now and 2040, depending on a variety of factors. The most important of these factors are great uncertainties about world oil reserves, technological capability to extract oil from the ground, capability to substitute other fossil fuel sources (coal, oil shale, oil sands) for oil, and development of alternative nonfossil fuel energy sources (wind, hydrogen, ethanol, nuclear, biomass). Other concerns relating to the US oil adequacy for the United States are potential disruptions in primary oil producing regions from terrorists, political turmoil, hurricanes, and uncertainty about future world oil demand. ${ }^{20}$

Even though the United States is currently the third largest oil-producing nation, US oil production peaked in 1970 and has been declining ever since. ${ }^{20}$ Therefore, US reliance on imported oil has steadily increased since 1970. In 2005, the United States imported about $66 \%$ of its oil and petroleum products (20). Although new energy sources are becoming available, oil demand in the United States is continuing to grow at nearly $1.5 \%$ per year. At the same time, oil demand in other parts of the world, particularly China and India, is expanding. The 2007 GAO report discusses problems with various energy alternatives, such as ethanol, hydrogen fuel cells, and hybrid vehicles. It concludes these energy alternatives have potential to reduce US reliance on imported oil but several years of development will be needed before their impact is significant. If peak oil should occur within the next 5 to 10 years, the consequences would be severe globally, but most dire for the United States because it is the world's largest oil consumer and most dependent on oil for transportation. ${ }^{20}$ Whereas the 2007 GAO report emphasizes US transportation vulnerability to peak oil, other reports show greater concern over food security. ${ }^{2,10}$

\section{Global Warming and Peak Oil}

Together peak oil and global warming are two of the biggest challenges confronting humanity as we move into the 21st century. The fourth assessment report (April 2007) of the Intergovernmental Panel on Climate Change (IPCC) leaves little doubt that global warming is occurring and is caused primarily from carbon dioxide emissions from human fossil fuel usage. The IPCC directly states the primary solution to global warming is to curb fossil fuel use and develop alternative energy sources. Basically the same set of energy solutions associated with peak oil apply to reducing global warming. However, the problems that global warming poses for world food security are different than those from oil depletion. It is probable global warming will adversely impact agriculture by making regional temperature and precipitation regimes annually more variable, with some areas becoming drier and others wetter. Intense droughts followed by intense flooding will likely occur much more frequently. Crop yield losses from insects and diseases will probably intensify. On a short-term basis (next 10 to 20 years), increases in atmospheric carbon dioxide levels from global warming might increase US crop yields. However, on a longer-term basis, increased aridity, coupled with erratic precipitation amounts and intensity, will likely reduce food production, particularly grain yields in the Great Plains.

Although I consider global warming a serious long-term food production threat in the United States, I believe peak oil to be the bigger short-term problem. I base this view on the 2007 GAO report that peak oil is impending and strongly urge the US federal government to develop a well-defined strategy to deal with its consequences. However, the news media and politicians have been placing more emphasis on global warming. Nevertheless, both peak oil and global warming will likely force major changes in both transportation and agriculture in the United States and world. Globalization vs localization is at the center of the debate over changes that will occur.

\section{Globalization versus Localization}

Globalization refers to the economic, social, and cultural integration of the world's various countries. ${ }^{2-4}$ Basically, globalization centers around unrestricted free trade among countries. International trade, free movement of capital and labor, and integration of financial markets are key features of globalization. Globalization depends heavily on removal of trade barriers (tariffs and quotas), international cooperation, and an abundant supply of cheap energy. Since World War II, the United States has been the world's largest promoter of globalization. In large part, this is because the United States is the world's largest economy. US multinational corporations, such as Wal-Mart and McDonald's, have greatly benefited by increased opportunities to sell their products in other countries. They also benefit from reduced labor costs, taxes, and environmental regulations that occur when they are able to relocate part or all of their business in countries such as China or India. Conversely, globalization has given American consumers a great deal of access to a wide variety of low-priced goods and foods produced in China, Japan, Mexico, Korea, India, and various other countries. Without question, living costs in America would be significantly higher (by some estimates, 20\% to $40 \%$ higher) without the globalization that has occurred over the last 15 years. George H. W. Bush, Bill Clinton, and George W. Bush have all been strong promoters of globalization and have accelerated its progress through various trade agreements.

In direct opposition to globalization, localization is a new term and movement that involves rearranging city and county level economies so they are self sufficient rather than dependent on high levels of imported food and 
energy. ${ }^{2,10}$ Key features of localization are transition to local, renewable energy sources, and food production from urban gardens and local agricultural lands. Basically, the localization movement is a counter response to peak oil, oriented toward natural resource and environmental sustainability. It emphasizes self sufficiency and renewability.

Globalization in moderation-involving some exchange of people, capital, goods, services, culture, and ideas among nations - is considered a positive thing by nearly all economists. ${ }^{8,9}$ The early free-market economist, Adam Smith, made the case that free trade improves human living conditions by lowering prices, increasing availability of goods and services, and raising employment. However, when free trade does not involve balanced trade, it can become socially and economically destructive. ${ }^{3-5}$ Since 1972 , when the US dollar became the world's reserve currency, the United States has increasingly engaged in unbalanced trade with increasing annual trade deficit now over 800 billion dollars. ${ }^{4,5}$ Once peak oil occurs, it will no longer be rational for countries such as China and India to send goods to the United States without receiving real goods, food, natural resources, or services in return. It seems most unlikely that the oil exporting countries will indefinitely accept mere paper dollars (if not fully backed by gold, goods, or food) for their commodity. Ultimately, I believe the United States could have two choices to meet its fossil fuel needs. One option will be to drastically change lifestyles of the people so they must depend much more on what the United States can produce internally, whereas the other will be for the United States to sustain its current lifestyle through projection of military force. I am hopeful that in the end, the United States will solve its energy problem through conservation, innovation, and development of its own resources. Under this choice, rangelands will play a critical role in national security.

\section{Current Status of Range Livestock Production}

Since the early 1980s, the role of range livestock production in meeting US food needs has been progressively diminished. In the mid-1980s, huge grain surpluses, coupled with historically low real (inflation adjusted) oil prices, made it feasible to produce high quantities of cheap meat using grains rather than range, pasture, and crop roughages as primary livestock feeds. ${ }^{21}$ At the same time, world beef production started expanding through conversion of tropical rain forests into pastureland in several South American countries. Globalization, coupled with cheap oil, made it feasible for the United States to import high quantities of low grade beef. Various subsidies, low labor costs, cheap transportation, and lack of environmental regulation gave beef production advantages to other foreign countries. The low meat prices and capability to import high food quantities since the mid-1980s have caused environmental groups and many politicians to view western rangelands as a nonessential, disposable resource that can be converted into nature reserves, wildlife sanctuaries, industrial parks, airports, recreational resorts, ski areas, golf courses, ranchettes, housing projects, etc., without adverse economic consequences. Ranching has come to be viewed much more as a cultural heritage and recreational activity than as an essential industry.

There is ample scientific information showing range livestock production to be the most environmentally benign and energy efficient of all land-based food production systems..$^{22,23}$ Problems of overgrazing have been greatly reduced across upland and riparian landscapes of the western United States based on my own observations. However, active investments (fire, herbicides, mechanical treatment, seeding) to improve western rangelands for food, water, fiber, and energy production have been meager. This neglect has caused a gradual decline in the forage-producing capability on many US rangelands. Across the western United States, brush and noxious plant problems are widespread. Although current data are lacking, in 1992 serious problems occurred on about $60 \%$ of our rangelands with minor problems on another $27 \% .^{24}$

If peak oil is near and major breakthroughs do not soon occur in development of alternative, clean, cheap energy sources, range livestock production could again play a vital role in supplying the United States with meat. Under conditions of peak oil without cheap alternative energy sources, food prices could rise sharply, particularly for meat. It might no longer be feasible to feed large quantities of grains to cattle because of their low conversion efficiency (about 10\%) into meat. Rather, most of the grain production would be directly consumed by humans or used for the ethanol production. Depending on severity of the oil shortage, limited amounts of grain will be fed to pigs and chickens because they more efficiently convert grain to meat than cattle. However, it is probable those meats will become very expensive and exceed grass-fed beef in per pound cost to consumers.

It is possible that both farming and ranching profits could increase as they did in the oil shock of the 1970s. There would likely be another major push to increase meat production from public and private rangelands. The role of large scale federal government assistance and subsidization of range improvements may again be debated by US Congress.

\section{Federal Funding for Range Improvements}

Under the 2002 Farm Bill, the federal government spends no more than 3 billion dollars annually on active improvements on private and public rangelands. This includes 1 billion dollars for the US Department of Agriculture's Environmental Quality Incentives Program (EQIP) for privately owned rangelands, administered by the Natural Resources Conservation Service. Total federal money spent on management of public and private rangelands is near 4 billion dollars. Remember, the federal government's 2007 budget is about 3 trillion dollars ( 1 trillion is 1,000 billion). 
Expenditure for the Iraq War will be near 100 billion dollars in 2007 and by year's end, the total 5-year cost will be 500 billion. From this, it is apparent annual federal funding for management and enhancement of the nation's rangelands is extremely low (about one tenth of one percent of the federal budget). On the other hand, rangelands comprise half of the nation's land area. If the money spent so far on the Iraq War would have been spent on improving the nation's rangelands, it would have amounted to five hundred dollars per acre.

\section{A Viewpoint Regarding the Future}

In my opinion, it would be wise for the United States to increase its investment in conservation, enhancement, and development of its rangeland resources as a rational hedge against the impending problems from peak oil and global warming. As a realist, I understand that under present conditions, capability to project military force is essential for the United States to ensure it obtains the vital natural resource imports (oil and natural gas) on which it is now so dependent. However, it seems both rational and prudent to minimize this dependency as quickly and as reasonably as possible. I recognize this will require a wide variety of strategies involving energy conservation, lifestyle changes, development of alternative energy sources, modifying transportation systems, and modifying food production systems. It seems to me that conservation and improvement of rangelands should be part of this strategy. How rangelands are used will undoubtedly affect future transportation and food security of the United States. For nearly 25 years, both low ranching profitability and lack of federal funding have caused a slow decline in forage productivity on many US rangelands, due to brush and noxious plant invasion. As the stands of brush and trees thicken and grow taller, the cost and difficulty of correcting the problem increases (Fig. 1). Eventually many of these lands become so dominated by

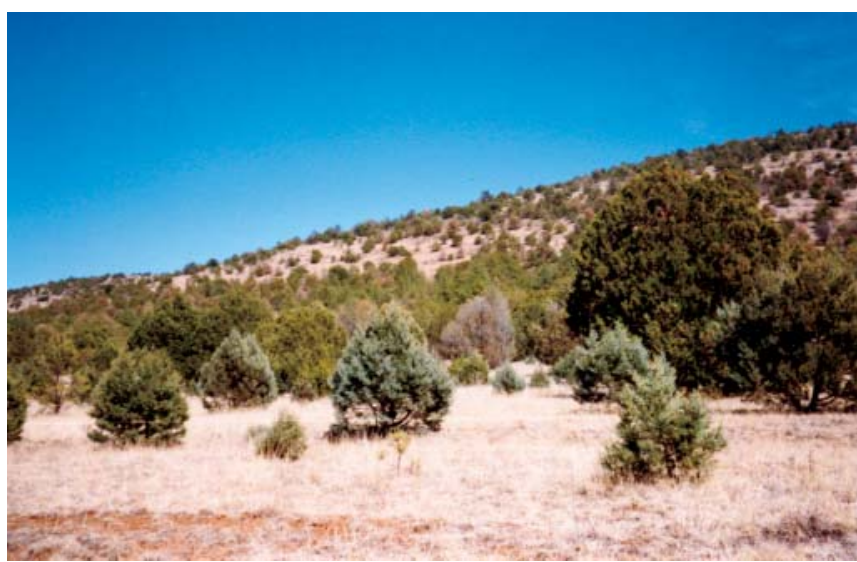

Figure 1. The value of this rangeland in western New Mexico for livestock, water, and wildlife is being gradually reduced by pinyon-juniper invasion. This problem occurs over large areas of New Mexico and other western states.



Figure 2. Grazing, farming, wildlife, and watershed values have been nicely integrated at the landscape level on this agricultural area in western Colorado.

woody vegetation they lose most or all of their value from forage, watershed, and wildlife standpoints.

A well-thought-out and -implemented strategy for improving the nation's rangelands, focusing on brush management, could accomplish several other objectives in addition to improving food security. Increased investment in our rangelands would reduce unwanted wildfire problems, increase employment, enhance watershed health, increase economic growth, enhance climatic stability, and improve wildlife habitat. The type of strategy I have in mind would emphasize self-sufficient local economies, keeping ranchers on the land, improve food security, and increase employment opportunities in ranching areas. It would emphasize integrating agriculture and nature (Fig. 2). A prosperous ranching economy would greatly curb conversion of rangelands into other uses. Food, energy, water, and wildlife would the primary products from this strategy.

On private lands, I suggest a program of low-interest government loans to ranchers for range enhancement (primarily brush control) with payback tied to livestock prices, agreements not to subdivide the ranch, and provision of ecosystem services. We now have sufficient research to apply brush and noxious plant control in ways that improve wildlife habitat while increasing forage for livestock (Figs. 3 and 4). Basically, the present EQIP program administered by the USDA-NRCS could be expanded and modified to meet this need.

On federal rangelands, uncertainty of grazing privileges, environmental regulations, and cost all necessitate that range improvement programs be government funded. It seems to me that the federal government that owns and controls these lands should also be responsible for maintaining and increasing their productivity for various uses (water, forage, wildlife, recreation, timber, etc.). Although I have serious concerns about ever-increasing federal debt levels, it seems that severe underinvestment is occurring on the nation's federal rangelands. 


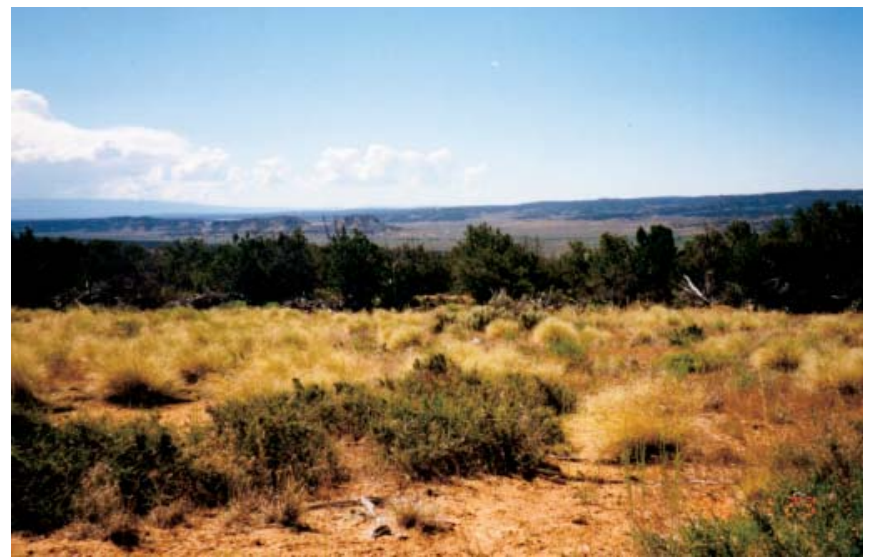

Figure 3. This pinyon-juniper control project in north-central New Mexico greatly improved forage for livestock, mule deer, and elk, as well as improving watershed and esthetic values.

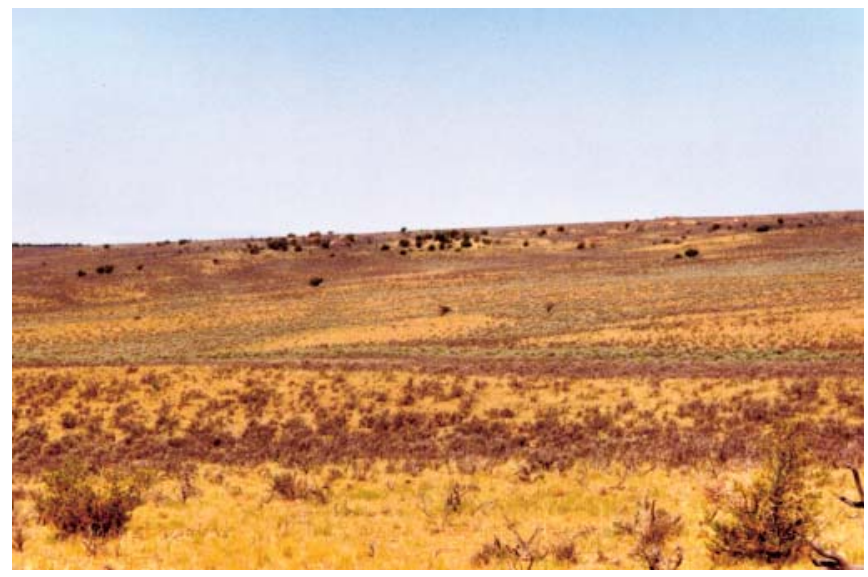

Figure 4. Big sagebrush was controlled leaving patches for wildlife and esthetic purposes on this rangeland in northwestern New Mexico.

I believe that a national land use committee is needed to assess the magnitude and implications of present land use patterns across the United States in terms of transportation, food, climatic, and economic security. The past and present trend for America to sprawl, or build out, rather than build up, does not seem rational and sustainable under conditions of peak oil and global warming.

\section{References}

1. Klare, M. T. 2004. Blood and oil. New York, NY: Henry Holt and Company. 277 p.

2. Kunstler, J. H. 2005. The long emergency. New York, NY: Grove Press. 525 p.

3. Faux, J. 2006. The global class war. Hoboken, NJ: John Wiley \& Sons, Inc. 324 p.

4. Duncan, R. 2005. The dollar crisis: Causes, consequences, cures. Hoboken, NH: John Wiley \& Sons. 292 p.

5. Prestowitz, C. 2005. Three billion new capitalists. New York, NY: Basic Books. 321 p.

6. American Farmland Trust. 2003. Why save farmland? Farmland Information Center fact sheet. Washington, DC: National Office. 3 p.
7. Staley, S. 2000. The "vanishing farmland" myth and the smart growth agenda. Reason Public Policy Institute. Policy Brief No. 12.17 p.

8. Schiller, R. R. 1991. The economy today. 5th ed. New York, NY: McGraw-Hill. 712 p.

9. Knutson, R. D., J. B. Penn, and B. L. Flinchbaugh. 1998. Agricultural and food policy. 4th ed. Upper Saddle River, NJ: Prentice Hall. 521 p.

10. Pfeiffer, D. A. 2006. Eating fossil fuels. Gabisola Island, British Columbia, Canada: New Society Publishers. 125 p.

11. Brown, L. R. 1998. Struggling to raise cropland productivity. In State of the World. World Watch Institute. New York, NY: W. W. Norton \& Co. p. 79-96.

12. Pyle, G. 2005. Raising less corn, more hell. Cambridge, MA: Public Affairs/Perous Books Group. 229 p.

13. Holechex, J. L., R. A. Cole, J. T. Fisher, and R. Valdez. 2003. Natural resources: Ecology, economics, and policy. 2nd ed. Upper Saddle River, NJ: Prentice-Hall. 761 p.

14. Chrispeels, M. J., and D. Sadava. 1977. Food, plants, and people. San Francisco, CA: W. H. Freeman. 238 p.

15. Pimentel, D., R. Harmon, M. Pacenza, J. Pecarsky, and M. Pimentel. 1994. Natural resources and an optimum human population. Population and Environment 15:347-369.

16. Pimentel, D., and M. Giampietro. 1994. Food, land, population and the U.S. economy. Cornell, NY: Carrying Capacity Network. 55 p.

17. Pirog, R., T. Van Pelt, K. Bushayz and B. Cook. 2001. Food, fuel and freeways: A Iowa perspective on how far food travels, fuel usage, and greenhouse gas emissions. Leopold Center for Sustainable Agriculture. Ames, IA: University of Iowa. 5 p.

18. Simmons, M. R. 2005. Twilight in the desert. New York, NY: John Wiley and Sons. 422 p.

19. Tertzakian, P. 2006. A thousand barrels a second. New York, NY: McGraw-Hill. 272 p.

20. United States Government Accounting Office (GAO). 2007. Crude oil: Uncertainity about future oil supply makes it important to develop a strategy for addressing a peak and decline in oil production. GAO Dept. 07-283. Washington, DC: Government Accountability Office. 76 p.

21. Holechek, J. L., J. Hawkes, and T. D. Darden. 1994. Macro economics and cattle ranching. Rangelands 16: 118-123.

22. Соок, C. W. 1976. Cultural energy expended in range meat and fiber production. Journal of Range Management 29:268-271.

23. Соок, C. W. 1979. Meat production potential on rangelands. Journal of Soil and Water Conservation. 34:168-171.

24. United States Department of Agriculture-Natural Resources Conservation Service. 1992. Natural Resources Inventory. Washington, DC: Government Printing Office. $188 \mathrm{p}$.

Author is Professor of Range Science, Department of Animal and Range Sciences, New Mexico State University, Las Cruces, NM 88003, holechek@nmsu.edu. This paper was supported by the New Mexico Agricultural Experiment Station and was part of project 1-5-27410. 


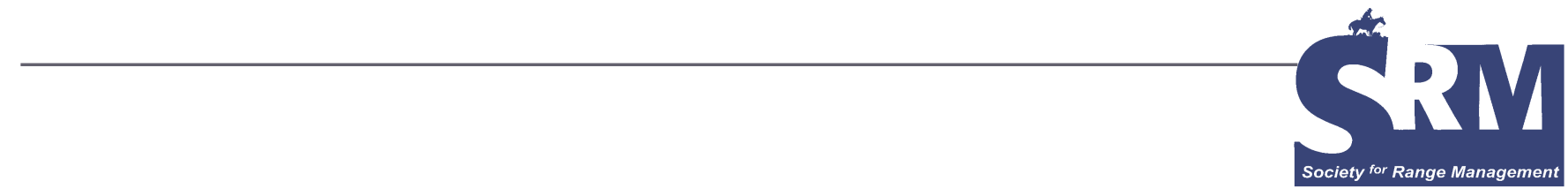

\section{Exploring Kentucky in 2008}

\section{From the rolling hills in the east to the beautiful lakes in the west, Kentucky has something for everyone. Kentucky is a state full of history and wonder, excitement and education. No matter what your interest, Kentucky can quench the thirst of any traveling enthusiast.}

\section{By Jennifer Johnson}



entucky, a state well known for being the horse capital of the world, came a long way throughout history. This land, originally noted as a hunting ground for Shawnee and Cherokee Indians, was not widely explored until the 1750s. After many treaties, the land was purchased from the Native Americans, and settlers began moving over the Appalachian Mountains and into the Cumberland Gap and Ohio River regions from Virginia, North Carolina, and Pennsylvania. One of the most famous explorers of this region, Daniel Boone, has been considered a founder of the state. At that time, settlers began introducing Kentucky to agricultural entities like tobacco, corn, and hemp. Kentucky's growth continued until the American Revolution, but because of ongoing violence in the region, there were fewer than 200 settlers in the area. After the Revolution, Kentucky County wanted to separate from Virginia. On June 1, 1792, Kentucky became the 15 th state added to the United States.

Kentucky may be known for its horses, horse parks, and bluegrass music, but it is also a state full of history. In the bluegrass region of the state, an area covering much of Lexington, Richmond, and Berea, we find a region once settled by Daniel Boone, rich with family tradition, and the birthplace of Bourbon. Kentucky is not only the birthplace of past presidents but also the birthplace of the "father of bluegrass" music, Bill Monroe. And what better to enjoy your bluegrass music than with some true Kentucky barbecue, found in the heart of Owensboro at Moonlite BarB-Q Inn, also the center of the much awaited for B-B-Q festival held each May.

For the explorer, Kentucky is a state perfect for adventure. Kentucky is home to one earth's natural creations, Mammoth Cave. Mammoth Cave National Park is a landmark worth exploring. From the vast caves to the everlasting trails, you could spend a lifetime amazed by the beauty that nature has created. With over 348 miles explored and mapped, Mammoth Cave is considered the longest recorded cave system in the world, with the National Park established to preserve the cave system, scenic river valleys, and parts of the hill country of south-central Kentucky. Mammoth Cave is a natural wonder open to the public year-round for all your exploring needs and is located only 90 miles south of Louisville.

Kentucky is a state rich with year-round attractions; from summer festivals to fall tours, there is always something to do. When visiting during the winter months, Louisville, Kentucky, is centrally located in a visitor's paradise, from downtown museums to expand your mind, to the new Fourth Street Live, known for its fun atmosphere, great food, and endless entertainment. If skiing the slopes is an adventure you crave, Paoli Peaks in Paoli, Indiana, is a mere 1.5-hour drive north from Louisville and has many 


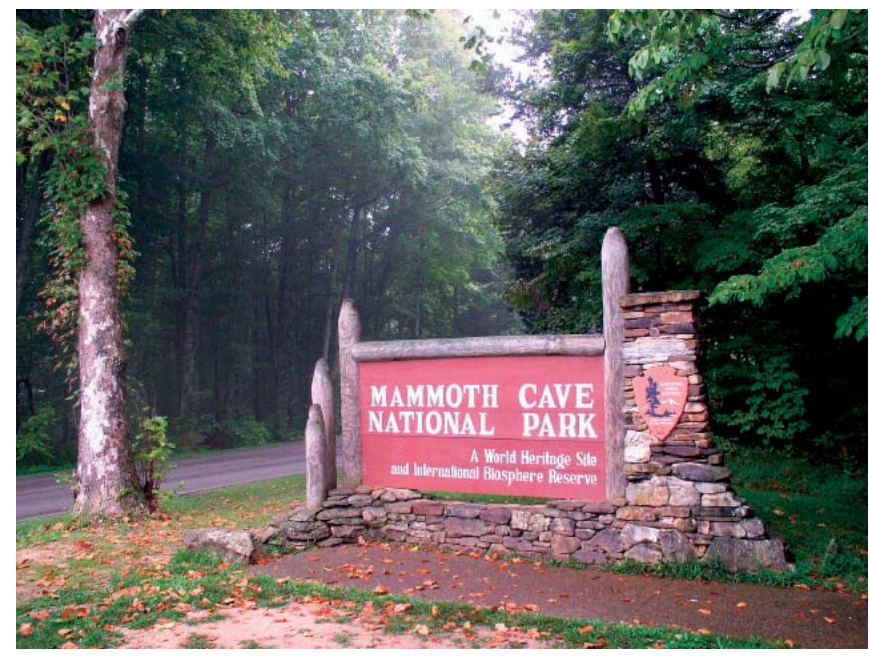

Mammoth Cave entrance.

opportunities for the skiing enthusiast. Whether you prefer daytime or nighttime skiing, this place has an option for everyone. For the prehistoric fanatic, a 10-minute drive can put you in the center of fossil heaven. Falls of the Ohio State Park, located on the river banks of the Ohio River just across from Louisville, is the home of one of the world's largest exposed fossil reefs from the Devonian Age. This wonder provides evidence that, more than 350 million years ago, an ocean once occupied the region that spreads from Louisville to Indianapolis.

Of course, if you visit Kentucky, there is often a desire to see the beautiful horse country that is Lexington. Just a short drive down I-64 and the beautiful countryside greets you with open arms. Lexington, Kentucky, is the home of numerous expansive horse farms throughout the area. A town full of history and wonder, Lexington is also the home of the Kentucky Horse Park, a major attraction for any visit. The Kentucky Horse Park, founded in 1978, is located on ground that has been the home of horses for more than 200 years. The park is dedicated to keeping alive the relationship between human and horse. An educational opportunity, the Kentucky Horse Park provides its visitors with the chance to see draft horses as they begin the day, participate in horse-drawn tours, and explore the Hall of Champions.

Kentucky is a state full of adventure and new beginnings. In Hodgenville, Kentucky, located an hour south of

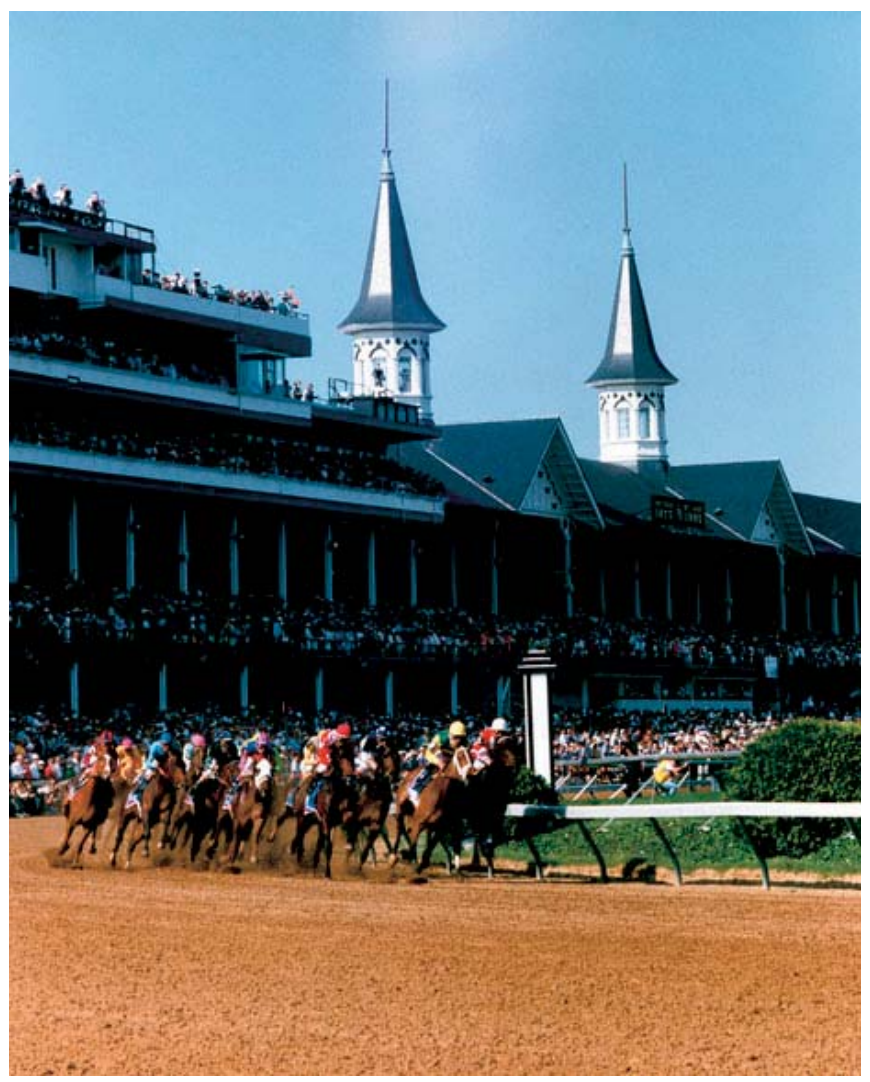

Churchill Downs.

Louisville, we find the birthplace of one of the great presidents, President Abraham Lincoln. Kentucky has served as the birthplace of many famous politicians, celebrities, and athletes, and Kentucky serves as the birthplace of the great American automobile. Bowling Green, Kentucky, is the home of the true sports car, the Chevrolet Corvette. The Corvette hit the automobile scene in 1953 and has been built exclusively in Bowling Green, Kentucky, for more than 55 years. Year-round, visitors drive into Bowling Green to tour the National Corvette Museum and to see just how these wonders were created and how they have evolved throughout the years.

Author is a Graduate Student, University of Kentucky, Lexington, KY 40508, jfj84@msn.com. 


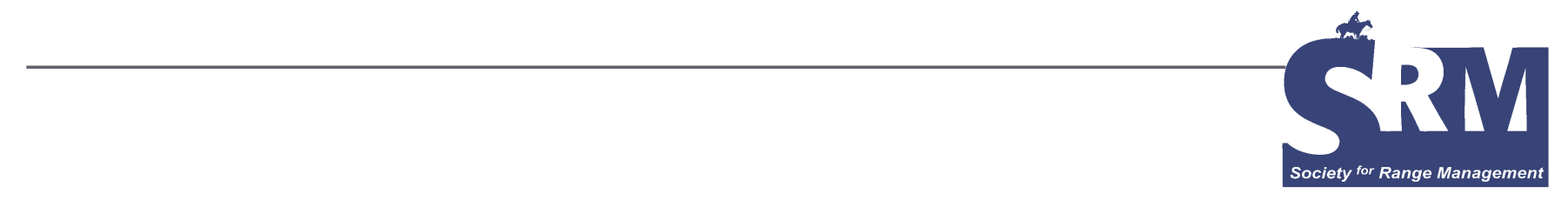

\section{Speaking With People in Our Profession}

\section{An interview with Dr. Mengli Zhao}

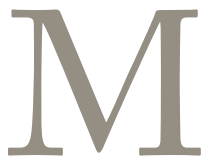

engli Zhao is a professor of rangeland management at the Inner Mongolian Agricultural University in Hohhot, China. Mengli is a member of the International Rangeland Congress Organizing Committee, and one of the hosts for the 2008 Congress to be held in Hohhot. She teaches classes in range management, mentors graduates students in range science, conducts research at experimental sites across Inner Mongolia, and her work as an extension agent for both China and foreign nongovernmental organizations operating in this region is highly respected and valued. Mengli has spent time in North America working with range science colleagues in both Canada and the United States. She found a few moments to answer questions while traveling by Land Cruiser across Inner Mongolia.

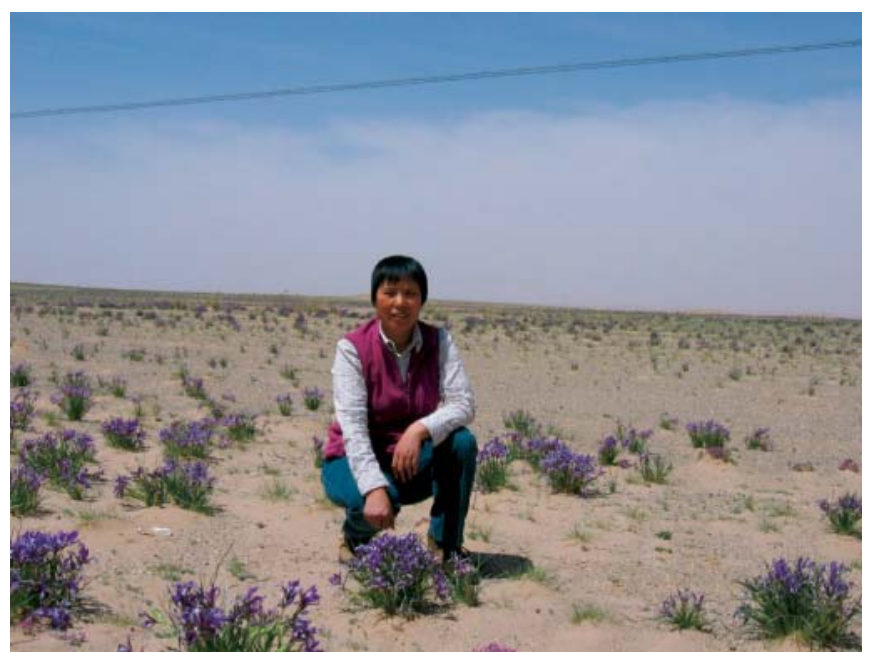

Dr. Mengli Zhou surrounded by flowering irises (Iris lactus) in a desert region of Inner Mongolia.

\section{A Witness to Remarkable Changes \\ Question: You've experienced tremendous economic and political changes in China over the last few decades. What are the most remarkable elements for you of these changes?}

Answer: Economic development is happening incredibly fast in our country. My generation experienced starvation several decades ago, and now we are seeing this countrywide development and abundance. It is hard for us to adapt to the pace of changes associated with this development.

\section{Even more than the political changes?}

Yes, the political reform is even behind the economic development.

\section{How do you think foreigners visiting China for the first time today will react to what they see?}

They won't know that China is as developed as it is. They might think they understand how China has changed and grown in recent years, but they really won't understand the rate of these developments until they see it for themselves. They will also be impressed by the extent of natural grasslands, especially those in Inner Mongolia. They will also find out about Chinese culture and Chinese food. They really don't have a good understanding of these cultural things from their experiences in their own countries.

\section{What are the range management problems facing China today?}

Certainly, overgrazing is the most serious problem, especially seasonal overgrazing in the spring. The grasslands are not ready for livestock use in the early spring. Some problems also are created by certain policies. Many of the herders do not have land ownership, and so they are not able 
to treat the land as their own, which would be better treated The herders have a lot of knowledge, and they know how to manage their uses.

\section{How are you trying to address these problems?}

The government is trying to implement policies such as the Grassland Law where the herders are under contract for a long period of time, up to 30 years, that allows them to treat the land more like their own. Some areas have now been set aside and grazing is forbidden for certain seasonal periods, although these grazing control policies still need to be modified to allow for appropriate uses. There are also a number of national programs that influence management practices. In addition, we have more science and technology that is being conducted and developed, which influences the amount of information available for making decisions. Finally, there are more extension programs that demonstrate proper practices.

\section{What opportunities are available to students graduating from your range management programs \\ in Chinese universities?}

Some will become teachers, some will become scientists, some will be extension specialists, some will become land managers, some will work for private business with interests such as land reclamation, or some will be directly involved in farming.

\section{They don't have trouble finding work?}

About $80 \%$ of them will find work in their field. Some will prefer to stay in the urban areas after school and not return to the field.

\section{Could a non-Chinese-speaking student attend} university in China, and, if so, what might it cost?

Yes, we have people from other countries in Asia, such as Japan and Mongolia, and these are often part of exchange programs. These are quite inexpensive-less than $\$ 250$ per month. We have not yet had many students from North America take advantage of these programs.

In your travels to other countries, do you find things very different from China, and do you find that some things are the same everywhere?

The food in other countries is quite different, and is one of the general things that always is different for me.
Also, there is a long cultural history in China. For example, I am used to a situation where a 500-year history of something in China is actually fairly new. For many other countries something 500 years old would seem quite ancient. Another difference is land ownership. Land in China can only be bought by Chinese, and can be bought from the government.

A key similarity is that the people involved in range management around the world have a lot in common, and they are quite similar. It doesn't seem to matter where a person is from; if they care about rangelands they have similar interests. Also, the grasslands in other parts of the world that I have seen also seem quite similar to those in China. It is easy to feel at home in other grassland areas outside of China.

\section{For people thinking about attending the International Rangeland Congress in Hohhot in 2008, what would you recommend they do and see in China during their visit?}

They should experience Chinese and Mongolian cultures as much as possible; these are cultures with long histories and are very different from anything they would have ever experienced. For Inner Mongolia and Outer Mongolia, these are cultures with long histories, and those histories are based on grasslands.

\section{What's harder to learn-English or Mandarin?}

Mandarin is more difficult, but the hardest part is to write the characters. The speaking part of Mandarin is actually easier than English. A person could learn several hundred words and sounds in Mandarin, and get around OK in China. And, I think, my English is a little bit better than your Chinese!

Interview by Susan R. McGuire, a pen name used by the author of this article. Her interviews with members of our profession are a regular contribution to Rangelands. All costs of publishing these interviews are sponsored by a research unit of the Agricultural Research Service, the in-house research agency of the United States Department of Agriculture, whose rangeland scientists are a segment of our Society. 


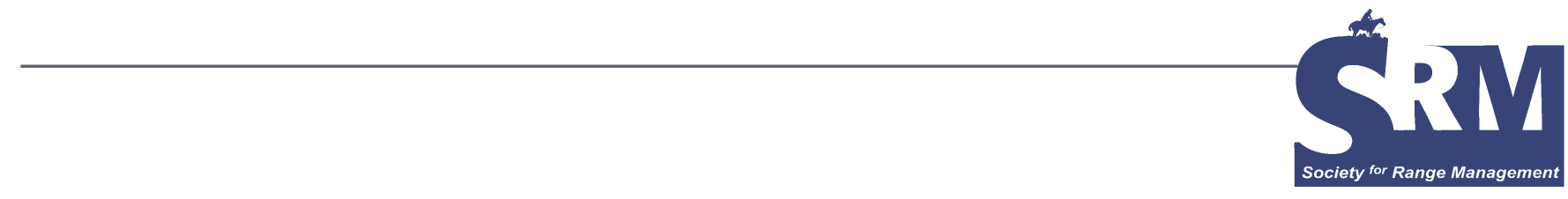

\section{Essays of a Peripheral Mind}

\section{Nei4 Meng2gu3, Zhong1 Guo2}

\section{By K. M. Havstad}

T here are over 500 million acres of grasslands in northern China. These rangelands extend along a west-east gradient from the Tarim Basin in northwest China across the Alasban and Mongolian Plateaus to northeastern China, a distance of over 3,000 miles. This is one of the world's largest expanses of rangeland still predominately used for livestock grazing. This mid-latitude region is extremely arid on the west within the rain shadow of the Himalayas and the Tibet Plateau and semiarid to the east across the temperate expanses of eastern Inner Mongolia, an autonomous region within China. For a very readable overview of the grasslands of this region see: National Research Council, 1992, Grasslands and Grassland Sciences in Northern China, National Academy Press, 214 p. Much of this region is relatively sparsely populated with a few interspersed large urban centers that are rapidly developing in concert with China's recent economic expansion. One urban example is the capital of Inner Mongolia, Hohhot (or Huhehot or Huhohaote), an industrialized city of $\sim 1.6$ million people (Fig. 1). Located about a one-hour flight northwest from Beijing, the capital of China, Hohhot is the site of the 2008 International Rangeland Congress (IRC) to be held June 29-July 5, 2008. Although Hohhot is a large city, this Congress location seems entirely appropriate given that over $20 \%$ of China's grasslands occur within Inner Mongolia and are readily accessible from Hohhot by car, bus, or train. The IRC meeting, to be conducted for the first time in collaboration with the International Grassland Congress (see: http://www.igc-irc2008.org/), is expected to attract 2,000 participants.
Today, the western media seem to post a daily headline, or more, on some aspect of China. These headlines often are global concerns such as trade imbalances, disproportionate influences on world economies, food safety warnings, dismal laborer conditions, or flaring tensions in the Korean peninsula. However, it is also quite likely that these headlines will concern environmental issues with direct ties to natural resource management. For example, see Evan Osnos' 2007 article from the Chicago Tribune on "China's Great Grab" about impacts of China's natural resource extractions at: www.chicagotribune.com/news/specials/chi-china-special, 0,6789511.special. These issues have direct relevance to land management anywhere around the world. I've been fortunate to have traveled in China, and visited Hohhot, several times in recent years. These Asian rangelands are stunning, expansive, and globally important.

It is extremely difficult to develop useful and accurate assessments of China, especially in meaningful ways by a novice on China such as myself. I know that traveling in Asia I struggle to sort through impressions in order to place environmental issues within an appropriate context, much the same way I work to understand western US ecological settings within the larger context of US politics and culture. However, the context of western US environments and their management issues is quite familiar to me. This is not the case in China, and I know I need a better grasp of the context of this Asian setting before I can more fully understand their resource management issues. Without a thorough ability to make effective assessments about context, I'm left with an array of impressions that will have to suffice for now. There are 3 impressions that I find most useful. 

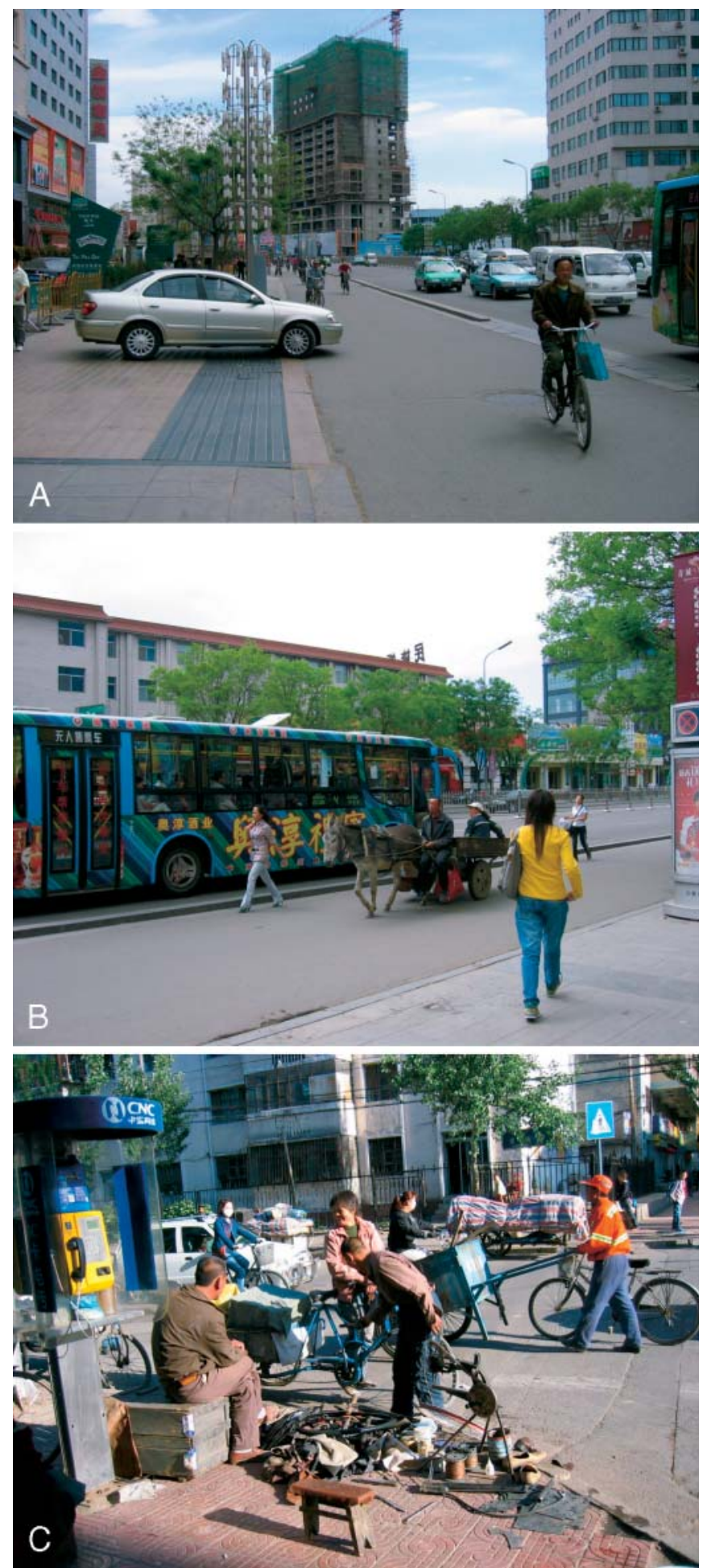

Figure 1. Hohhot, the industrialized capital of Inner Mongolia and the host city for the 2008 first joint meetings of the International Rangeland Congress and the International Grassland Congress, is a rapidly growing city of approximately 1.6 million people that characterizes urban, modern-day northern China with its $A$ ) rampant new construction, B) intermingled diverse modes of transportation, and C) opportunistic enterprises including street corner bicycle repair "shops."
One impression is based on language. Chinese is actually a family of many spoken dialects, including 2 main forms of Chinese, Cantonese and Mandarin. Though there are many dialects, and Cantonese is a popular form of Chinese, about $95 \%$ of Chinese people speak Mandarin, the official language of China. It is, of course, a language based on characters, or hanzi. I am not sure how many characters exist in the Chinese language, maybe 50,000 or more. Each character is unique, and each has its own sound and tone. Some characters have even been simplified from their traditional form to be more easily drawn and recognized. You do not need to be able to read 50,000 characters to understand Chinese. It might take 2,000 to understand rudiments of conversation, and 3,000 to be able to read a newspaper. Reading a detailed book can require 20,000 or more. Training for basic conversational skills in Mandarin requires over 2,000 hours of classroom instruction, but learning Chinese is probably a life-long endeavor. Irrespective of the time required or difficulty, learning even one Chinese character for a non-Mandarin speaker is greatly assisted by the use of pinyun, the use of the English alphabet to spell out the sounds of a Chinese character. For example, the word "China" in pinyun is "zhong guo," the English spelling of the sound of each of the two characters (中国) that comprise the word "China." Chinese, though, is a tonal language. So, it is not just the pinyun sounds "zhong guo" that characterize the word "China," but also the fact that "zhong" is pronounced with the flat tone (the first tone represented by the \#1) and "guo" is pronounced with an ascending tone, the second (\#2) of 4 tones that characterize Mandarin. The other tone sounds are one that both descends and then ascends (tone \#3), and a descending tone (\#4). There are characters in Chinese that are neutral (without tone), but these are few. Hence, the title of this essay is in Mandarin, and is the pinyun spelling, with tone numbers, for "Inner Mongolia" (Nei4 Meng2gu3), "China" (Zhong1 Guo2). This language impression though goes beyond intricacies of the language and its difficulty for non-Chinese. It includes 3 basic statistics: over $20 \%$ of the world's population speaks Chinese, over 300 million Chinese youth are learning English, and fewer than 50,000 US youth are learning to speak Chinese. Our future abilities to understand each other and the context of our environmental issues as determined by language will not be equivalent between the English-speaking world and the Chinese-speaking world. The Chinese will likely become more globally adept.

A different impression is of general human landscapes in China. It is assumed that China is ubiquitously densely populated, but that seems true for only 2 of these 3 landscapes. One landscape is the urban setting that is probably most familiar, at least through commonly communicated visual images. These visuals are key Chinese cities with their trademark images such as Tiananmen Square in Beijing, the financial districts of Hong Kong, and the expansive shopping malls of Singapore. A second landscape is the densely populated rural landscape of south China. Interestingly, this 
is the region that actually has seen tremendous population growth over the past half century from over 400 million people to now well over 700 million people. Although it is densely populated, it includes large, intensively farmed regions. A third landscape is the relatively sparsely populated rangelands of northern China. For example, Inner Mongolia is about the combined size of California, Oregon, Washington, and Arizona, but with 23 million people, it has about $45 \%$ of the population of these 4 western US states. There are cities such as Hohhot with large urban populations (Hohhot would be the fifth largest city in the United States by population), but much of Inner Mongolia maintains a distinctively rural and pastoral nature with a relatively low population density (Fig. 2).

A third impression, more pertinent to the rangelands of this third human landscape, emerges from the history of Inner Mongolia. There is often confusion in the western world - a world in which many of us are quite geographically challenged beyond our own borders - in recognizing that Mongolia and Inner Mongolia are 2 different countries. In the early 13th century, when Temujin, a great grandson of Kabul Khan, was given the title Chinggis Khan, ruler of the Mongolian Steppe, there was only one Mongolia (see David Sneath's book "Changing Inner Mongolia" published in 2000 by Oxford University Press for a historical overview of this region). For the next $200+$ years Chinggis Khan and his descendants ruled an empire that extended across Persia and into central Europe. This empire expanded and contracted with the succession of deaths and realignments within the ruling families. The Mongolian conquest of Asia subsided with the rise of the Chinese Ming Dynasty in the 15th century. By the mid 17th century the Chinese Qing Dynasty established control over China but recognized and rewarded the descendants of Chinggis Khan while incorporating Mongolian culture into China. During this period Mongolia was organized into an Inner region that could be controlled by the government in Beijing, and an Outer region ruled by military governors. This division was formally recognized in the early 20 th century by Russia, which shares thousands of miles of common border with Outer Mongolia (or, simply, Mongolia), and later recognized by China in the mid-20th century. Mongolia actually celebrated its 800th anniversary in 2006. Part of this third impression is simply that I am unfamiliar with the full set of implications resulting from a cultural history of this length and complexity. But it is more than that. It has been recorded that nearly 800 years ago Chinggis Khan remarked "So long as we do not tear the holy skin of the golden land, and do not change the natural appearance of the vast grasslands, then the grassland is the best natural garden without any human imprint" (see: Zhang et al. 2007. Mongolian nomadic culture and ecological culture. Ecological Economics 62: 19-26). I work with a research group that prides itself on continuing a long (95 years in 2007) history of recorded observations at our location. Obviously, we are just getting started.
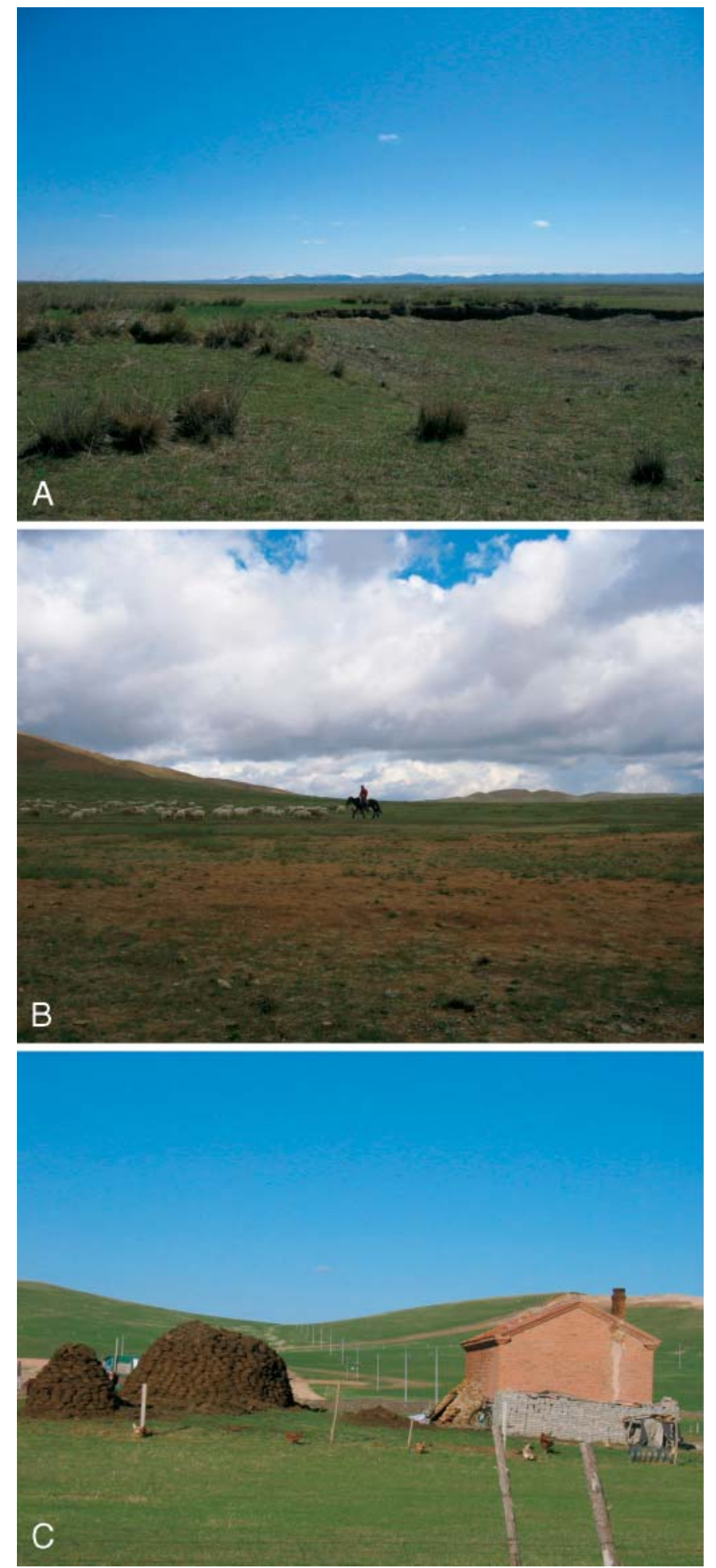

Figure 2. Rural Inner Mongolia, despite a complex history of rulers and governments over the past 8 centuries, has remained A) pastoral with B) an indigenous herder lifestyle that C) relies on opportunistic energy sources.

Collectively, these impressions don't put me in a position to place an appropriate context based in culture, politics, and history around these Chinese rangelands and their management. They do, though, create a tremendous appreciation for 
what can be learned especially given that Inner Mongolia has remained linked to its pastoral roots, and continues to support an indigenous herder lifestyle. It might very well be that these rangelands have been degraded in recent decades, and face serious problems with global consequences (see Olnos's article, or see: Bedunah et al. 2006. Rangeland of Central Asia. USDA, USFS, Proceedings RMRS-P-39). Although these historical, political, social, cultural, and economic settings in Asia might be quite different from that with which I am familiar, the rangeland landscapes are familiar, and the relevant scientific concepts and management principles of my experiences have some applications.
More importantly, my concepts and principles have an opportunity through interactions in Inner Mongolia to be expanded and revised from lessons that others have drawn from $8+$ centuries of recorded experiences. It would help, though, if I could at the least understand even a few basics of their language.

Author is Supervisory Scientist, USDA/ARS Jornada Experimental Range, PO Box 30003, MSC 3JER, New Mexico State University, Las Cruces, NM 88003-8003, khavstad@ nmsu.edu. 




Thad Box

\section{We Can't Stop the World-Just Buckle Our Spurs for the Ride}

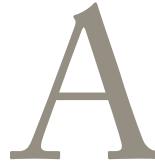

s I write, a fire races up the mountain a few miles east of me. Smoke mixes with air already polluted by automobiles. Crews from several communities try to keep the fire out of conifers. Choppers, working like bees, take water from First Dam. Planes circle overhead. A tanker drops red retardant to slow even redder flames. The Fire Marshall says they don't know how it started.

It began near a new housing development, half-million-dollar houses built on mule deer winter range. Vegetation is mostly cheatgrass with islands of sagebrush and scrub maple that survived past fires. Plants are tinder dry from drought. Any spark could send a wave of flames up the mountain into juniper and then fir. The fire has dropped a power line. If it is not stopped in the next half mile, it could be a big one.

Our land care profession started because rangelands in the late 19th century were barren and livestock were dying. People did not understand why the lush grasslands had disappeared, or more importantly, how to get them back into production.

Scientists responded to that specific social and economic need. Over the decades we learned how land communities develop, the causes for deterioration, and the conditions necessary for rebuilding those communities. We found that plant communities are mainly controlled by soil and available moisture. Each community has its unique web of interconnections and dependencies among biota, geologic material, and climate.

Eroded farmland, overgrazed rangelands, overcut forests, and surface mines are drastically disturbed lands. When the earth is turned upside down, land loses purpose and productivity. Interconnectedness within natural communities is severed. Rehabilitation depends on re-establishing connections, mending relationships, and working with natural processes to form community.

Rehabilitating the burning mountain east of me will not consist simply of scattering seeds and protecting the area from grazing. Growing conditions and interconnections will not be the same as those of the cheat grass community before the fire. Nor can we easily return to the conditions of the plant community the first Europeans found there. The growing human population's desire for McMansions has drastically disturbed land and its natural interconnectedness.

Geologic history tells us that there have been many catastrophic events that profoundly changed the earth. Meteors have hit our planet and created dust that closed out the sun for long periods of time. The earth has wobbled on its axis. Ice ages have come and gone. Populations of plants and animals were destroyed. Others changed or died because they could not adapt to the new conditions. New organisms evolved. And new relationships 
between land and its inhabitants were formed. Communities were established and thrived-until the next drastic disturbance.

Some in the range management profession argue that if livestock grazing is removed from the land we have no reason to exist. They point to the direct relationship between the overgrazing in the late 1800s and the beginning of the profession. But to understand the need for land care professions, we need to look at the biological, physical, social, and economic principles that govern healthy communities, not just the health of a given industry or use of land.

This does not mean we abandon the Trail Boss image or deny our cowboy roots. It means we turn our scientific knowledge to the land and whatever communities it can support in a given environment-new or old. It matters little that the environment changed from causes beyond our control. We cannot stop the world, nor can we go back to the good old days. Our mission is to understand and work with change.

Today rangelands are plagued with drought, floods, and fire. Hundreds of thousands of acres lie barren. Politicians declare whole states disaster areas. And they rush to subsidize the inhabitants to rebuild their structures and industries. They rebuild in spite of good evidence that the basic environment is changing and the old communities might not fit current situations.

Apparently we are on the cusp of one of those drastic, perhaps catastrophic, changes. The earth is warming. The amount of carbon dioxide in the air is increasing. An overwhelming majority of scientists believe those events are human-caused, primarily from increased burning of fossil fuels. A small, but vocal minority deny that the climate change is human caused. An even smaller minority say the climate is not changing.

The growing majority of public opinion and political action want to stop, or at least slow down, emissions that are related to the earth's warming. The chances of stopping greenhouse gas production are very low. And even if we could stop all fossil fuel burning, the climate will continue to warm for generations. As the climate changes, land managers will be called upon to devise systems to adapt. Our role, at least in the foreseeable future, is to apply principles we have learned to rapidly changing environment-climatic, social, and economic.

Perhaps we are fortunate to live in such unstable times. The process of adaptation to new conditions might well trigger a new wave of scientific understanding and social development. Biologists have long recognized that evolution is most rapid in disturbed areas. Organisms tend to mutate or cross with others when their lives are changed radically by environmental disruption. New species of grasses arise on road cuts, new forbs on mine dumps.
Scientists at the Smithsonian and our national Natural History Museum suggest that great moments in human evolution are associated with periods of rapid climatic change. During the last 5 million years there have been 67 periods of wildly varying climate. It was during those times of rapid climate change that the great moments of human evolution occurred: walking upright, making tools, art, exit from Africa, and the development of Homo sapiens.

About 99\% of the world's scientists believe the earth is warming and that the cause is a buildup of greenhouse gases, mostly from burning fossil fuels. I, along with most land care professionals, am part of that majority. We might buy more fuel efficient cars and cut energy use. But our main expertise is not in the macro-science level of climatic change. We are people who work with communities during change. We play close attention to trend, changes-both positive and negative- that we can measure.

To reverse a downward trend, land managers try to remove the cause for deterioration, and restore natural interrelationships within the community. We have a lot of research on how this is done. It has served us well in improving poorly managed rangelands, or cropland that is poorly husbanded. We have a good track record on bringing back lands that have been neglected or overused.

But our tried and true procedures for mismanaged land might not fit drastically disturbed lands. Concepts of "state and transition" succession demonstrate that a point might be reached where the controlling factors (usually soils or climate) have changed enough that the old interrelationships cannot be re-established. A new environment exists. A new community of new actors with their own special interconnections is more likely to succeed. We can use principles of adaptation we learned wearing the trail boss hat to assure new and different communities are successful.

The burning benches east of me represent various levels of the prehistoric Lake Bonneville. When the first white settlers came, the benchlands were covered with perennial grasses similar to the Palouse Prairie. Mountain sheep and elk were the main grazers. European use changed those communities to annual grass-sagebrush vegetation. Cattle in summer and mule deer in winter grazed the areas. Now grazers are gone. Luxury houses fill the landscape.

Soon the City Council, County Commissioners, State Department of Natural Resources, and USDA Forest Service will work together to get vegetative cover on the burned areas to keep mud slides out of the new neighborhoods.

This fire could be a metaphor for the future of western rangelands. The future of our land care profession might well depend on our ability to adapt. We can't stop the world and get off. Buckle up your spurs for the ride.

ThadBox,thadbox@comcast.net. 


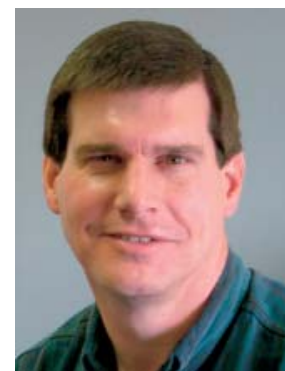

By Jeff Mosley

\section{Browsing the Literature}

This section reviews new publications available about the art and science of rangeland management. Personal copies of these publications can be obtained by contacting the respective publishers or senior authors (addresses shown in parentheses). Suggestions are welcomed and encouraged for items to include in future issues of Browsing the Literature. Contact Jeff Mosley,jmosley@montana.edu.

\section{Animal Ecology}

Aspen and conifer heterogeneity effects on bird diversity in the northern Yellowstone ecosystem. J. P. Hollenbeck and W. J. Ripple. 2007. Western North American Naturalist 67:92-101. (Dept. of Forest Resources, Oregon State Univ., Corvallis, OR 97331). Aspen stands invaded by conifers did not have higher bird species diversity than pure aspen stands.

Evidence for regionally synchronized cycles in Texas quail population dynamics. J. J. Lusk, F. S. Guthery, M. J. Peterson, and S. J. Demaso. 2007. Journal of Wildlife Management 71:837-843. (Dept. of Natural Resource Ecology and Management, Oklahoma State Univ., Stillwater, OK 74078). From 1978-2002, wet-dry weather cycles (5-6 years in duration) coincided with fluctuations in bobwhite quail populations.

Linking occurrence and fitness to persistence: habitat-based approach for endangered greater sage-grouse. C. L. Aldridge and M. A. Boyce. 2007. Ecological Applications 17:508526. (US Geological Survey, 2150 Center Ave, Building C, Fort Collins, CO 80526). In dry mixed-grass prairie of southern Alberta, sage grouse-selected nesting and brood-rearing sites within patchy distributions of moderate sagebrush cover.

Population-specific demographic estimates provide insights into declines of lark buntings (Calamospiza melanocorys). A. A. Y. Adams, S. K. Skagen, and J. A. Savidge. 2007. Auk 124:578-593. (Dept. of Fish, Wildlife, and Conservation Biology, Colorado State Univ., Fort Collins, CO 80523). Nest predation was responsible for $92 \%$ of nest failures by lark buntings in shortgrass prairie of eastern Colorado.

Seasonal diet and foraging preference of greater kudu Tragelaphus strepsiceros in the Llano Uplift of Texas. S. S. Gray, T. R. Simpson, J. T. Baccus, R. W. Manning, and T. W. Schwertner. 2007. Wildlife Biology 13:75-83. (T. Schwertner, Dept. of Biology, Texas State Univ., San Marcos, TX 78666). Greater kudu, a large African ungulate introduced into central Texas, is a browsing animal with diet preferences similar to white-tailed deer.

Second chance for the plains bison. C. H. Freese, K. E. Aune, D. P. Boyd, J. N. Derr, S. C. Forrest, C. C. Gates, P. J. P. Goyan, S. M. Grassel, N. D. Halbert, K. Kunkel, and K. H. Redford. 2007. Biological Conservation 136:175-184. (Northern Great Plains Program, World Wildlife Fund, PO Box 7276, Bozeman, MT 59771). Advocates immediate actions 
to achieve the ultimate goal of returning tens of thousands of "largely wild and free-roaming" bison to the Great Plains.

Survival of pronghorns in western South Dakota. C. N. Jacques, J. A. Jenks, J. D. Sievers, D. E. Roddy, and F. G. Lindzey. 2007. Journal of Wildlife Management 71:737-743. (Dept. of Wildlife and Fisheries Sciences, South Dakota State Univ., Brookings, SD 57007). Coyote predation was the primary cause of pronghorn fawn (or kid) mortality. Concealment cover is important for fawn survival during late spring-early summer.

\section{Hydrology/Riparian}

Rangeland grazing as a source of steroid hormones to surface waters. E. P. Kolodziej and D. L. Sedlak. 2007. Environmental Science and Technology 41:3514-3520. (Dept. of Civil and Environmental Engineering, Univ. of California, Berkeley, CA 94720). Estrogens were present at levels suspected to harm fish in 10\%-20\% of water samples collected from rangeland creeks where cattle had direct access to the stream.

\section{Measurements}

Canopy spectra and remote sensing of Ashe juniper and associated vegetation. J. H. Everitt, C. Yang, and H. B. Johnson. 2007. Environmental Monitoring and Assessment 130:403-413. (USDA-ARS, 2413 E. Hwy 83, Weslaco, TX 78596). Ashe juniper in central Texas could be distinguished on color-infrared aerial photographs and on QuickBird false color satellite imagery.

Ecological site descriptions and remotely sensed imagery as a tool for rangeland evaluation. C. L. Maynard, R. L. Lawrence, G. A. Nielsen, and G. Decker. 2007. Canadian Journal of Remote Sensing 33:109-115. (R. Lawrence, Dept. of Land Resources and Environmental Sciences, Montana State Univ., Bozeman, MT 59717). Satellite imagery accurately identified rangeland sites that were outside the norm in productivity and exposed soil, as defined by their ecological site descriptions. This technique can help identify sites needing more management attention.

Monitoring with a modified Robel pole on meadows in the central Black Hills of South Dakota. D. W. Uresk and T. A. Benzon. 2007. Western North American Naturalist 67:46-50. (US Forest Service, Rocky Mountain Research Station, 1730 Samco Rd, Rapid City, SD 57702). Recommends sampling with 3 transects and 20 stations per transect when using a Robel pole to quantify standing herbage.

\section{Plant Ecology}

Common groundsel (Senecio vulgaris) seed longevity and seedling emergence. R. Figueroa, D. Doohan, J.
Cardina, and K. Harrison. 2007. Weed Science 55:187-192. (K. Harrison, Dept. of Crop Science, Pontificia Univ. Catolica Chile, Vicuna Mackenna 4860, Santiago 7820436, Chile). Almost all groundsel seeds (94\%) either germinated or died after 2 years of deep burial in a silt loam soil in Ohio.

Does species diversity limit productivity in natural grassland communities? J. B. Grace, T. M. Anderson, M. D. Smith, E. Seabloom, S. J. Andelman, G. Meche, E. Weiher, L. K. Allain, H. Jutila, M. Sankaran, J. Knops, M. Ritchie, and M. R. Willig. 2007. Ecology Letters 10:680689. (US Geological Survey, 700 Cajundome Blvd, Lafayette, LA 70506). An analysis of 12 grassland ecosystems found that increased plant species diversity did not increase grassland productivity.

Elton's hypothesis revisited: an experimental test using cogongrass. A. R. Collins, S. Jose, P. Daneshgar, and C. L. Ramsey. 2007. Biological Invasions 9:433-443. (Dept. of Biology, Univ. of Vermont, Burlington, VT 05405). In loblolly pine and longleaf pine forest sites in Florida, plant species diversity did not affect the invasibility of sites by cogongrass, an exotic grass invading large areas of the southeastern United States.

Evaluation of central North American prairie management based on species diversity, life form, and individual species metrics. L. A. Brudvig, C. M. Mabry, J. R. Miller, and T. A. Walker. 2007. Conservation Biology 21:864-874. (Dept. of Natural Resource Ecology and Management, Iowa State Univ., Ames, IA 50011). A mosaic of burning and grazing (alone and in combination) is recommended to provide the greatest landscape-level plant species diversity in tallgrass prairie.

Soil water partitioning contributes to species coexistence in tallgrass prairie. J. B. Nippert and A. K. Knapp. 2007. Oikos 116:1017-1029. (Division of Biology, Kansas State Univ., Manhattan, KS 66506). In Kansas tallgrass prairie, $\mathrm{C}_{3}$ and $\mathrm{C}_{4}$ plants coexist by partitioning soil water. $\mathrm{C}_{4}$ plants depend on water in shallow soil layers, whereas $\mathrm{C}_{3}$ species only use shallow soil water when it is plentiful and use deeper soil water as the upper soil layers dry.

Vegetation responses to 35 and 55 years of native ungulate grazing in shrubsteppe. E. A. Rexroad, K. H. Beard, and A. Kulmatiski. 2007. Western North American Naturalist 67:16-25. (K. Beard, Dept. of Wildland Resources, Utah State Univ., Logan, UT 84322). Moderate elk densities did not affect plant biomass or cover under moderate climatic conditions; however, plant biomass and cover were reduced when grazing/browsing occurred by elk in a drier environment and by deer in a colder environment. 


\section{Rehabilitation/Restoration}

Aspen in the Sierra Nevada: regional conservation of a continental species. P. C. Rogers, W. D. Shepperd, and D. L. Bartos. 2007. Natural Areas Journal 27:183-193. (College of Natural Resources, Utah State Univ., Logan, UT 84322). Reviews aspen ecology in the Sierra Nevada Mountains of California and recommends the reintroduction of mixed-severity wildfires to promote aspen growth.

Does the type of disturbance matter when restoring disturbance-dependent grasslands? A. S. MacDougall and R. Turkington. 2007. Restoration Ecology 15:263-272. (Dept. of Botany, Univ. of British Columbia, Vancouver, BC V6T $1 Z 4$, Canada). In a degraded oak savanna in southwestern British Columbia, burning, mowing and raking, and weed control were all equally effective at suppressing exotics and increasing native plant growth because all treatments increased the availability of light for the native plants.

Effects of species richness on resident and target species components in a prairie restoration. J. K. Piper, E. S. Schmidt, and A. J. Janzen. 2007. Restoration Ecology 15:189-198. (Dept. of Biology, Bethel College, North Newton, KS 67117). In tallgrass prairie restoration, planting diverse seed mixtures increased the diversity and rate of establishment of desired plant communities, but there was no benefit to planting more than 8 species in a mixture.

How planting method, weed abatement, and herbivory affect afforestation success. B. W. Sweeney, S. J. Czapka, and L. C. A. Petrow. 2007. Southern Journal of Applied
Forestry 31:85-92. (Stroud Water Research Center, 970 Spencer Rd, Avondale, PA 19311). Tree shelters effectively protected hardwood tree seedlings from deer browsing, and protecting seedlings from browsing was more important than either the method of tree planting or the method of controlling weeds.

Nasella pulchra survival and water relations depend more on site productivity than on small-scale disturbance. K. Lombardo, J. S. Fehmi, K. J. Rice, and E. A. Laca. 2007. Restoration Ecology 15:177-178. (J. Fehmi, School of Natural Resources, Univ. of Arizona, Tucson, AZ 85721). In California annual grassland, clipping surrounding nonnative annuals did not affect the performance or survival of purple needlegrass seedlings.

\section{Socioeconomics}

Conservation easements: biodiversity protection and private use. A. R. Rissman, L. Lozier, T. Comendant, P. Kareiva, J. M. Kiesecker, M. R. Shaw, and A. M. Merenlender. 2007. Conservation Biology 21:709-718. (Dept. of Environmental Science, Policy, and Management, Univ. of California, Berkeley, CA 94720). Among a sample of 119 conservation easements held by The Nature Conservancy, $46 \%$ were working landscape easements that allow ranching, forestry, or farming.

Jeff Mosley is Professor of Range Science and Extension Range Management Specialist, Department of Animal and Range Sciences, Montana State University, Bozeman, MT 59717. 


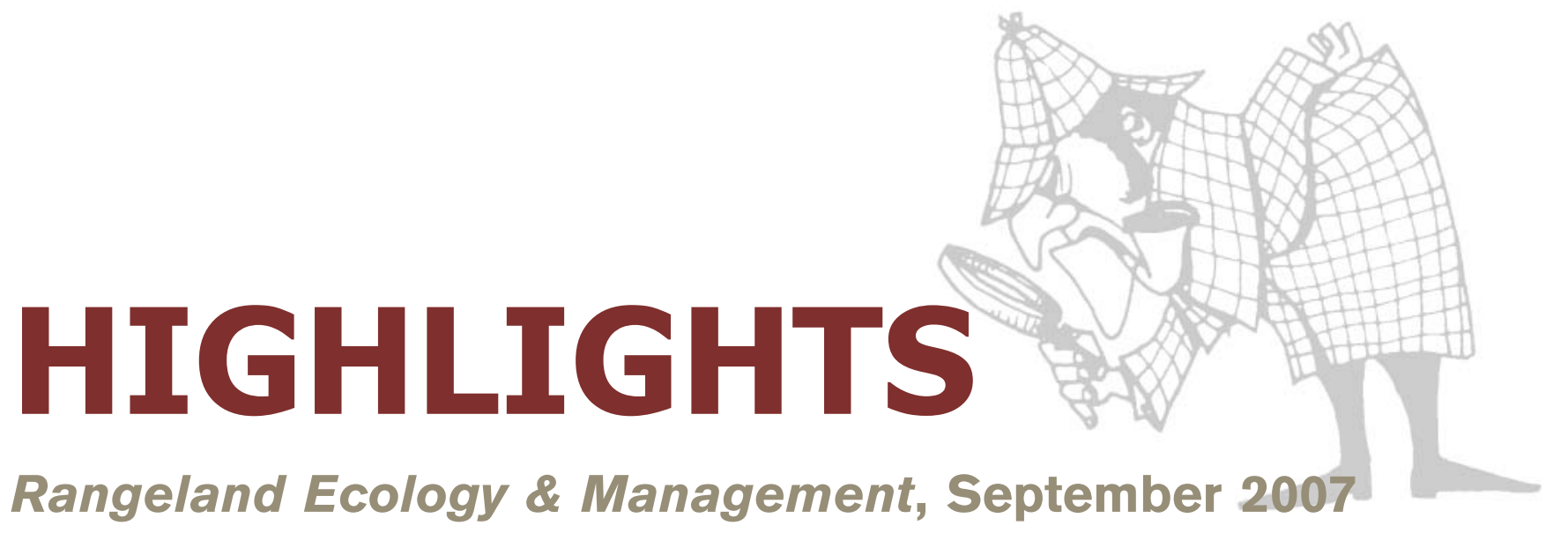

\section{Successional Transitions and Management of a Phosphorus-Limited Shrubland Ecosystem}

Zalmen Henkin, No'am G. Seligman, and Imanuel Noy-Meir

The decline of traditional pastoral systems has highlighted the problem of managing shrub encroachment on successional shrublands in the Mediterranean region. We studied shrub and herbaceous cover in a burned area in response to phosphate application and chemical shrub control. Without herbicide, shrub cover reached its preburn level within 5 years, but with herbicides, it had not yet reached the preburn level after 17 years. Phosphate application did not influence shrub cover but increased herbaceous vegetation cover. Appropriate use of grazing, shrub control, and phosphate amelioration can develop open woodlands with herbaceous understory with a wide range of ecological services.

\section{Ecosystem Water Use Efficiency in a Semiarid Shrubland and Grassland Community}

\section{William E. Emmerich}

Water use efficiency (WUE), net carbon uptake per water lost, is higher in $\mathrm{C}_{4}$ grasses than $\mathrm{C}_{3}$ shrubs. We measured evapotranspiration and $\mathrm{CO}_{2}$ fluxes at a shrub and grass site in southeastern Arizona. Two different methods were used to evaluate ecosystem WUE. Results indicated that the grass-dominated ecosystem was between 1.4 and 1.6 times more water use efficient than the shrub-dominated ecosystem. Mean annual growing season precipitation and evapotranspiration were similar in the two ecosystems, but the higher WUE of the grassland system enabled it to take up more carbon during the growing season than the shrub ecosystem.

\section{Effect of Phosphate Fertilization on Flooding Pampa Grasslands (Argentina)}

Adriana M. Rodríguez, Elizabeth J. Jacobo, Pablo Scardaoni, and Víctor A. Deregibus

We evaluated the effect of phosphate fertilization on the production and relative contribution of legumes and grasses of native and old tall fescue (Festuca arundinacea Schreb.) grasslands managed under rotational grazing. Two fertilization programs (66 and $29 \mathrm{~kg} \mathrm{P} \cdot \mathrm{ha}^{-1}$ supplied as rock phosphate and/or mono-ammonium phosphate) and a nonfertilized control were performed. In native grassland, phosphate fertilization increased aboveground net primary productivity (ANPP) of $\mathrm{C}_{3}$ annual grasses and legumes; therefore, annual ANPP under $66 \mathrm{~kg}$ P·ha ${ }^{-1}$ doubled ANPP of nonfertilized treatment. Phosphate fertilization did not increase total annual ANPP of old tall fescue grassland but it did increase ANPP of legumes.

\section{Grazing and Burning Japanese Brome (Bromus japonicus) on Mixed Grass Rangelands}

\section{K. R. Harmoney}

Japanese brome has invaded the central and northern Great Plains and negatively impacted native vegetation and grazing animals. Annual prescribed spring burning and annual early spring grazing were compared to measure effects on Japanese brome density and native vegetation composition. Annual spring burning and spring grazing were equally effective in limiting Japanese brome density compared to the idle control. However, Japanese brome was present even after five years of annual burning and intense early spring grazing, which indicates the difficulty of eradicating Japanese brome from ecosystems where it has become naturalized.

\section{Decreasing Forage Allowance Can Force Cattle to Graze Broom Snakeweed (Gutierrezia sarothrae) as a Potential Biological Control}

Michael H. Ralphs, Randy D. Wiedmeier, and Jeffrey E. Banks

Although overgrazing is a principal cause for the increase in broom snakeweed, prescriptive grazing can provide the means of controlling it. Cattle were confined to narrow grazing lanes and moved each day, and forage was limited to $24 \%-75 \%$ of their intake requirement. Cattle grazed $62 \%-95 \%$ of snakeweed plants and utilized $50 \%-85 \%$ of its 
biomass, without adversely affecting their health or body condition. Cattle can be an effective biological control by confining them to small areas and limiting alternative forage to force them to graze snakeweed.

\section{Bluebunch Wheatgrass Response to Spring Defoliation on Foothill Rangeland}

Tracy K. Brewer, Jeffrey C. Mosley, Daniel E. Lucas, and Lisa R. Schmidt

Spring elk grazing can reduce forage availability for wildlife or livestock in summer and harm forage resources on foothill rangeland. Early spring defoliation of bluebunch wheatgrass (Pseudoroegneria spicata [Pursh] A. Love) did not affect leaf height, plant yield, or inflorescence production in summer on either site. However, late spring defoliation adversely affected bluebunch wheatgrass plants in summer when grazed for 2-3 successive years on the foothill grassland and sagebrush steppe sites. Managers should carefully monitor bluebunch wheatgrass stubble height immediately after ungulate grazing in May on foothill rangeland and make appropriate adjustments to maintain the sustainable production of bluebunch wheatgrass.

\section{Effects of Fire Frequency and Intensity on Mesquite in an Arizona Grassland}

Carl E. Bock, Linda Kennedy, Jane H. Bock, and Zach F. Jones

Attempts to control velvet mesquite with fire usually have failed, perhaps due to insufficient fuels and lack of repeated burning. We measured fire damage and 5 years of postfire recovery for mesquite trees in Arizona grasslands differing in wildfire history and presence vs. 34-year absence of livestock. Mesquite mortality was $18 \%$ in ungrazed areas burned twice in 15 years, $1 \%$ in ungrazed areas burned once, and $0 \%$ in grazed sites. Repeated fires likely could have prevented the historic spread of mesquite, but probably could be used to control mesquite today only in areas with abundant fine fuels.

\section{Short-Term Effects of Burning Wyoming Big Sagebrush Steppe in Southeast Oregon}

Kirk W. Davies, Jonathan D. Bates, and Richard F. Miller

We quantified the impact of fall burning on shrub and herbaceous production and cover, vegetation diversity, soil water content, soil nitrogen and carbon, and soil organic matter in Wyoming big sagebrush communities. Total vegetation production and cover were greater in the control than burned treatment. However, greater herbaceous production and cover in the burned than unburned treatment suggests resources became available to herbaceous vegetation with burning. Annual exotic grass cover and production did not increase with burning. Herbaceous vegetation can be increased with prescribed burning of Wyoming big sagebrush communities without exotic annual grass invasion.

\section{Large-Scale Aerial Images Capture Details of Invasive Plant Populations}

\author{
Dana Blumenthal, D. Terrence Booth, Samuel E. \\ Cox, and Cara E. Ferrier
}

Locating and measuring invasive weed populations across large areas is key to understanding, monitoring, and managing rangeland invasions. We tested a novel approach that uses a lightweight airplane, flying at $100 \mathrm{~m}$ altitude, to rapidly collect high resolution images, each representing $48.5 \mathrm{~m}^{2}$ of mixed-grass prairie. From these images we were able to efficiently and reliably measure small patches and even individual plants of the invasive forb Dalmatian toadflax. These results suggest that such high-resolution aerial imagery could be used to obtain detailed measurements of many invasive weed populations.

\section{A Fence Design for Excluding Elk Without Impeding Other Wildlife}

Kurt C. VerCauteren, Nathan W. Seward, Michael J. Lavelle, Justin W. Fisher, and Gregory E. Phillips

Concentrated herbivory by elk can degrade vegetative communities and alter ecosystem processes. Woven wire fence can exclude other, nontarget animals. We designed a simple fence that excluded elk, but maintained access for other species. We monitored effectiveness with trackplots, animalactivated cameras, and changes in aspen stem height and density. Our fence excluded elk, but allowed other animals access. After 1 year of protection, mean aspen stem height increased in the exclosure, but stem density changed little. Our fence design excluded elk and has potential for protecting a variety of resources.

\section{Will Molasses or Conditioning Increase Consumption of Spotted Knapweed by Sheep?}

\section{Travis R. Whitney and Bret E. Olson}

The spread of the invasive, Eurasian spotted knapweed (Centaurea maculosa Lam.) across the northwestern United States would be reduced if livestock regularly consumed it. We determined if white-face yearling ewes conditioned for 12 days to fresh-cut spotted knapweed, with or without molasses, would increase their use of it during a 5-day field trial and/or a 4-day drylot trial. Conditioning yearling ewes to spotted knapweed, with or without molasses, did not significantly increase consumption of this invasive plant, possibly because sheep inherently graze spotted knapweed only to a certain extent, or we did not use enough spotted knapweed during conditioning. 
Influence of Fire on Black-Tailed Prairie Dog Colony Expansion in Shortgrass Steppe

David J. Augustine, Jack F. Cully, Jr., and Tammi L. Johnson

Management of black-tailed prairie dogs can affect both livestock and biodiversity in semiarid rangelands. We examined the influence of prescribed burns on prairie dog colony expansion in shortgrass steppe, and found the mean rate of expansion was twice as high for colonies expanding into burned compared to unburned grassland. However, under the dry conditions during our study, expansion rates of unburned colonies were highly variable. Our results indicate burns can ensure that an individual colony expands rapidly, but burning had only minor effect on the overall colony complex because a portion of the unburned colonies also expanded rapidly.

\section{Extent of Stem Dieback in Trembling Aspen (Populus tremuloides) as an Indicator of Time-Since Simulated Browsing}

Allan W. Carson, Roy V. Rea, and Arthur L. Fredeen

In the absence of direct observation, determining when plant shoots are cropped by ungulates is difficult to assess. We investigated the utility of using stem dieback as a means of determining when the shoots of aspen stems were clipped (simulated browsing). Although stem dieback itself was not a reliable indicator of when it was that shoots were clipped, calculating the ratio of dieback along the stem to what was available for dieback, allowed for an accurate assessment of time-since browsing. The technique provides a reliable assessment tool for managers interested in mapping seasonal browse use by domestic and wild ungulates.
Digital Photography: Reduced Investigator Variation in Visual Obstruction Measurements for Southern Tallgrass Prairie

Ryan F. Limb, Karen R. Hickman, David M. Engle, Jack E. Norland, and Samuel D. Fuhlendorf

Managing landscapes with structural heterogeneity is critical for wildlife populations; however, traditional visual obstruction techniques used to measure vegetation structure are subject to high observer variability. We developed a digital image method to measure visual obstruction and compared it to the Robel pole and Nudds' coverboard methods. The digital method was a robust technique with the lowest observer variation along the gradient of vegetation structure tested. Research programs that utilize seasonal field technicians and are subject to high annual turnover could benefit from implementing use of the digital image method to obtain more reliable data and to reduce sampling effort.

\section{Saltcedar Water Use: Realistic and Unrealistic Expectations}

\section{Keith Owens and Georgianne W. Moore}

Saltcedar (Tamarix spp.) is a widespread invasive plant found in riparian corridors and floodplains in 16 western states. Popular press articles widely report that each individual saltcedar tree can use as much as 200 gallons per day. We use 3 lines of evidence-peer-reviewed scientific literature, sap flux rates and sap wood area, and potential evaporation rates - to demonstrate the improbability that saltcedar, or any other woody species, can use this much water per tree on a daily basis. A more realistic estimate of maximum daily water use derived from sap flux measurements would be less than 32.2 gallons. 
Fundamentals of Beef Management. By David J. Drake and Ralph L. Phillips, Technical Editors. 2006. University of California and Natural Resources Communication Services, Oakland, CA. 140 p. US\$18.00 paper. ISBN-13: 978-1-879906-73-0.

Authors and contributors to this publication include Sheila Barry, Gary Beall, Mike Connor, Daniel J. Drake, Jim Farley, Rhonda Gildersleeve, Nancy Hinkle, Bill Kvasnicka, John Maas, Glenn A. Nader, James W. Oltjen, Ralph L. Phillips, Ron Torell, and Bill Weitkamp.

Fundamentals of Beef Management is written as a technical resource guide for new producers in California. As the editors explain in the introduction, "success in the cattle business requires more than securing some pasture and buying a few cows or steers; you will need land, time, money, and knowledge about the many aspects of beef production," and "advances in beef cattle production are increasingly more technical." This book contains information that would be beneficial to new producers across the nation, covering everything from breeds and genetics, handling facilities and equipment, fencing, and transportation to nutrition and calving.

Chapter 7, "Animal Health," does a good job of discussing infectious disease agents that affect cattle in the United States. Chapter 12, "Irrigated Pasture," is a very well-written, well-organized, thoughtprovoking overview of using irrigated pasture to produce forage for beef cattle. This chapter covers carrying capacity, stocking rate, the forage production cycle, water management, and the cost effectiveness of irrigated pasture in a direct and easy-to-understand writing style. A beef cattle producer just starting a business in the state of California will appreciate Chapter 19, "Regulations," as well as Appendix B, "Branding and Inspection of Beef Cattle."

I would have preferred a more comprehensive discourse on the subjects of range management and economics. Although the book would be difficult to use as a reference because of its chapter organization and format, it does contain useful information for producers.

Dwayne Rice, Society for Range Management, Kansas Section, Lincoln, KS.

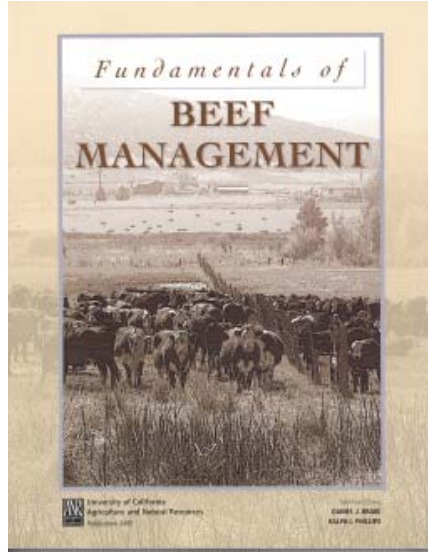


American Windmills: An Album of Historic Photography. By T. Lindsay Baker. 2007. University of Oklahoma Press, Norman, OK. 156 p. US\$34.95 hardcover. ISBN-13: 978-0-8061-3802-2.

American Windmills is truly an album of historic photographs. Author T. Lindsay Baker purchased his first old photograph of a windmill in a junk shop, paying no more than a dollar. In 1974 he took a blackand-white photography class and bought his first single-lens reflex camera. From then on his search for historic windmill pictures became unstoppable. He soon discovered that scores of public repositories and private collections contained photographs of windmills, and he secured reproductions of the best images. In preparation for this book the author along with his editor looked at approximately 2,000 photographs to select the ones used.

Acknowledgment is given to the late B. H. "Tex" Burdick, Sr., of E1 Paso, Texas, who from the 1920s through the 1940s photographed his employees doing the many jobs involved in windmill erection and maintenance. Burdick allowed the author to copy his collection onto safety film. Other picture sources were the archives of the firms that made the windmills. Many other archivists and librarians also provided pictures. An expert historian on windmills for 25 years, the author brings to the reader an informative text along with this album of windmill pictures.

Windmills were introduced to this country in the 1620s when English immigrants erected them first in Virginia. These Old World windmills generally had "four blades covered with canvas sails and had to be directed by hand to face the wind." This type of windmill worked well for grinding grain, but they were large and expensive. Farmers and livestock raisers needed small wind machines for pumping water and limited grinding of grain.

In 1854 the first design for a self-governing commercially successful American windmill was invented. By the 1870s a substantial number of factories for their manufacture had been opened. As more factorymade windmills appeared on the market, the demand grew. Many buyers would assemble and erect their own windmills, but soon dealers, well drillers, and others would perform this service. On large ranches in the West, where windmills made it possible for humans and their animals to live, owners would employ crews specifically to make the rounds of servicing the windmills. Agriculturists used the power of the wind to bring up groundwater that otherwise would have to be pumped by hand.

Baker's album chapters cover windmill manufacturers and distribution, marketing, erection and maintenance, effect on western ranching, farmsteads, railroads, and urban settings. Many of the photos depict farm families posed with their farm animals in front of their homesteads and windmills. One picture shows a springtime party gathered on their farm with their windmill prominent in the background. More windmills were used on farms than anywhere else.

Another important use of windmills was along railroad tracks, where locomotives stopped to take on replacement water. In many areas local governments funded the sinking of wells and the construction of windmills for public use, including people who relied on horses and mules for transportation. In urban settings municipalities started placing windmills over public wells to provide residents with clean water. Some communities constructed entire water-work systems using windmills to pump water into central reservoirs. In the 1860s American-made windmills were exported overseas, taken by boxcar to ports for shipment over the ocean. These windmills can still be seen in southern Africa and Australia.

A photo album rich in text and carefully selected photos, American Windmills introduces the reader to a range of settings and uses of the windmill. From the ranch to the farm, alongside railroads, in industry and urban settings, the author takes us on a historical journey through America.

Jan Wiedemann, Society for Range Management, Texas Section, College Station, TX.

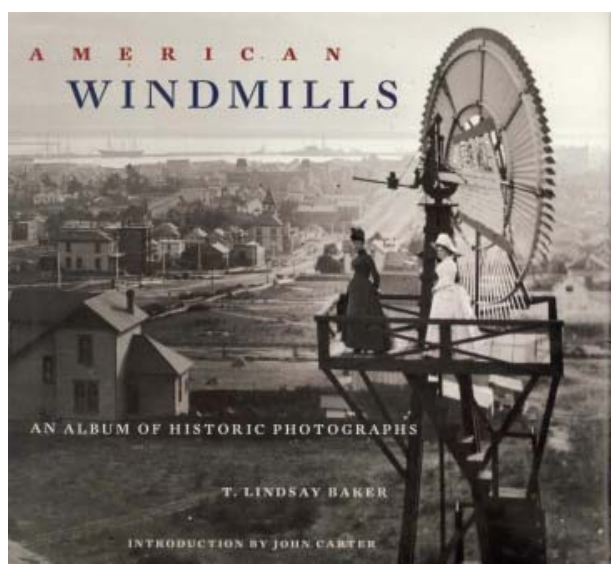


Letter

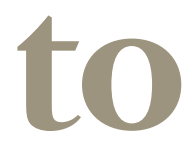

To the Editor:

The December Rangelands (Volume 28, No. 6, p. 7-14) featured an article entitled "Rangeland Research: Strategies for Providing Sustainability and Stewardship to Rangelands of the World" by Marty Vavra and Joel Brown. It was based on a symposium at the Fort Worth SRM annual meeting two years ago. This research needs symposium traditionally reviews progress and suggests new directions. The assessment is mandated every decade according to our SRM Science and Ecology Division.

I found this report refreshing and informative. Twenty scientists from various backgrounds outlined rangeland research needs and accomplishments under ten broad topics. Topics were general areas of research emphasis and varied from "Livestock and Rangelands" to "Rangeland Policy and Economics."

I, however, would like to have seen an entirely new topic of research added to this undertaking. This topic would deal with the influence of livestock herbivory on co-inhabitants of rangelands-the indigenous creatures whose habitats they share. Rangeland research has made good progress in grazing strategies for riparian and aquatic habitats as well as practices for restoration. However, I feel we are remiss in not attacking head-on problems involving the effects of herbivory on species already listed or those approaching Threatened or Endangered (T\&E) status.
Recent political events suggest the Endangered Species Act is here for the long haul and any reauthorization will emerge without much modification. Research needs as envisioned by SRM should be proactive in this area. Decision makers and managers will need the best science available regarding practices for restoring $\mathrm{T} \& \mathrm{E}$ species.

SRM should forge partnerships that foster cooperative multi-disciplinary research to provide ecological information upon which to build sound recovery plans for at-risk species, especially those potentially linked to effects of livestock herbivory. Adaptive management and/or ecosystem stewardship are not suitable strategies in dealing with such near listed or rare species. This can only come from cause-effect research. And who better than range scientists to provide analysis of biodiversity and evaluate critical habitats?

I feel SRM research should take the lead in investigating the ecological effects of herbivory on $T \& E$ components of rangelands. It is time for our membership to recognize this critical need and bring to bear the strengths of our organization to aggressively attack this problem in the coming decade.

Jon M. Skovlin Cove, OR

Viewpoints expressed above are opinions of the author, who is a certified consultant in range management and in wildife management and has over forty years of research experience. He is a lifetime member of SRM. 